B O N N E V I L L E P O W E R A D Lake Roosevelt Rainbow Trout Habitat/Passage Improvement Project;

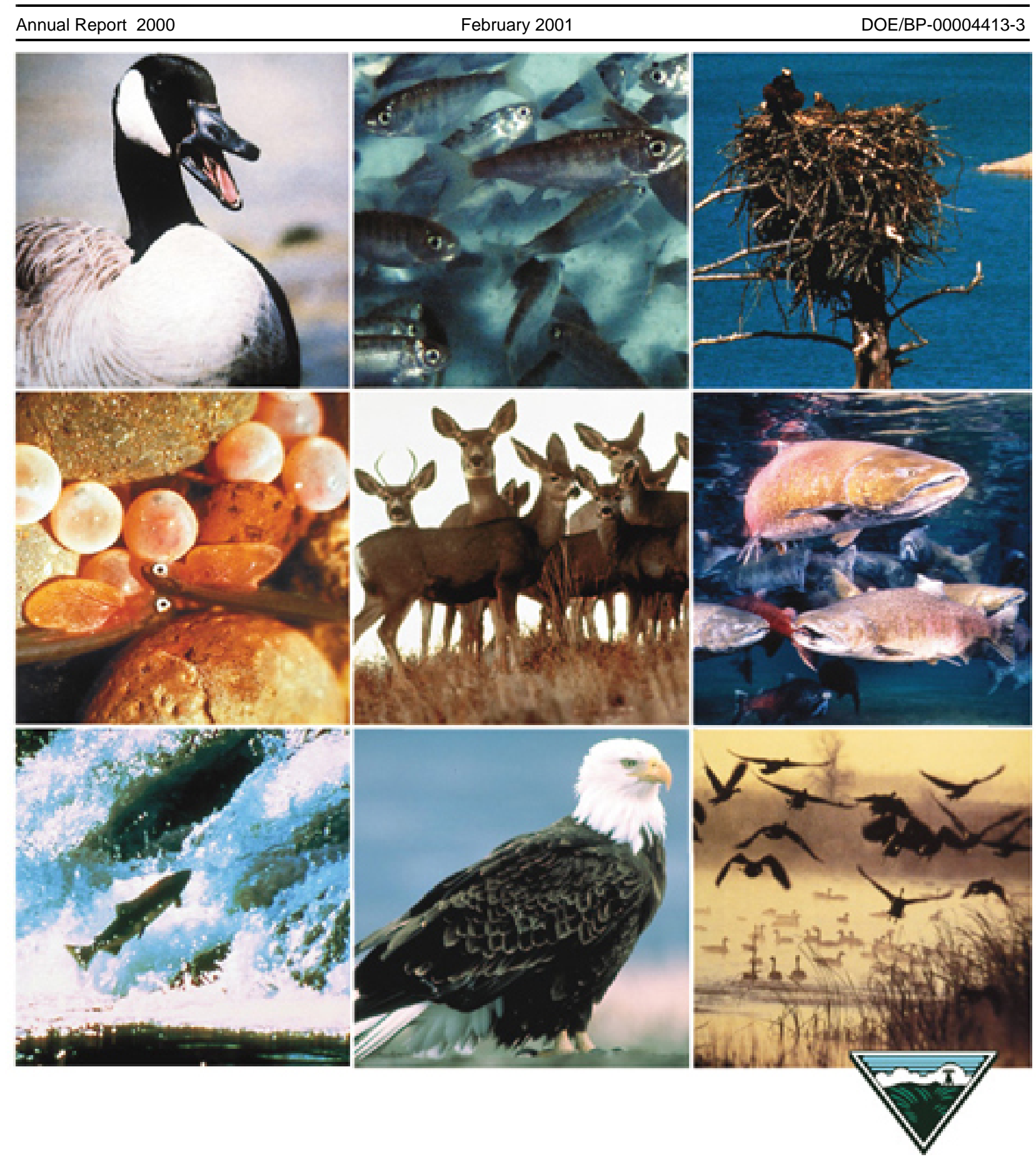


This Document should be cited as follows:

Sears, Sheryl, "Lake Roosevelt Rainbow Trout Habitat/Passage Improvement Project;", 2000

Annual Report, Project No. 199001800, 64 electronic pages, (BPA Report DOE/BP-00004413-3)

\author{
Bonneville Power Administration \\ P.O. Box 3621 \\ Portland, OR 97208
}

This report was funded by the Bonneville Power Administration (BPA), U.S. Department of Energy, as part of BPA's program to protect, mitigate, and enhance fish and wildlife affected by the development and operation of hydroelectric facilities on the Columbia River and its tributaries. The views in this report are the author's and do not necessarily represent the views of BPA. 


\title{
Lake Roosevelt Rainbow Trout
}

\section{Habitat/Passage Improvement Project}

\author{
Annual Report \\ January 2000 - December 2000 \\ Prepared by: \\ Sheri Sear, Fisheries Biologist \\ Confederated Tribes of the Colville Reservation
}

Prepared for:

Charlie Craig, BPA Project C.O.T.R.

Bonneville Power Administration

Department of Energy

Box 3621

Portland, OR

Project No. 199001800

Contract Number - DE-BI-79-90BP08120 


\section{Table of Contents}

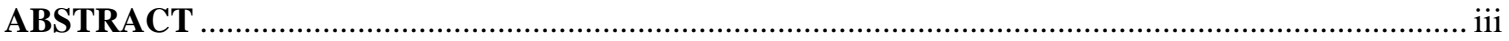

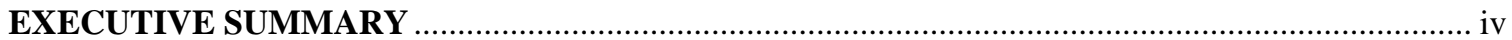

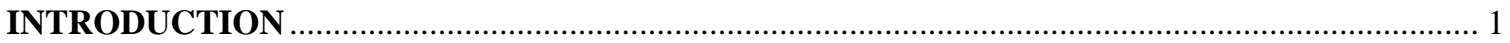

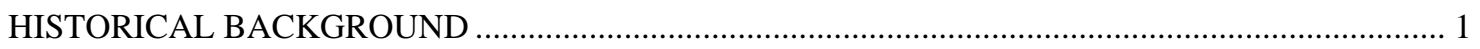

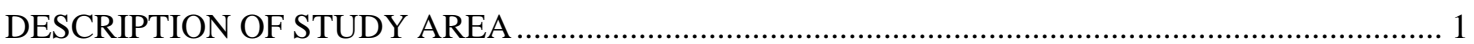

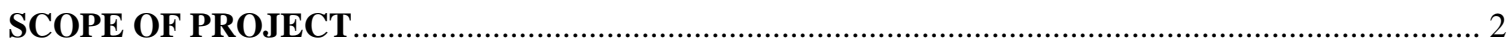

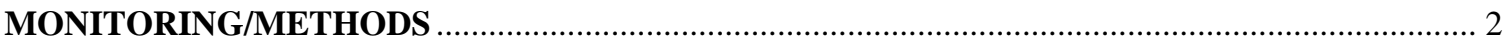

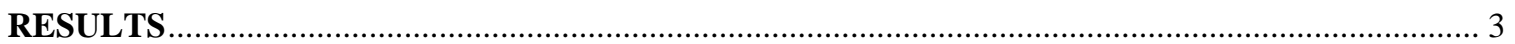

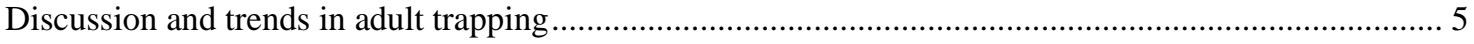

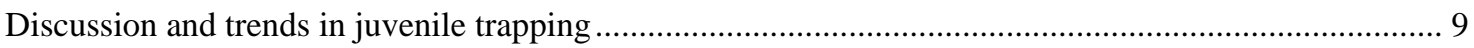

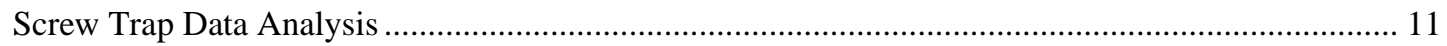

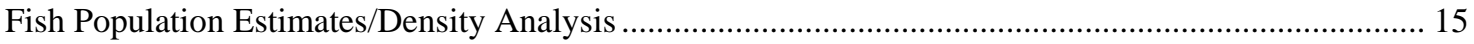

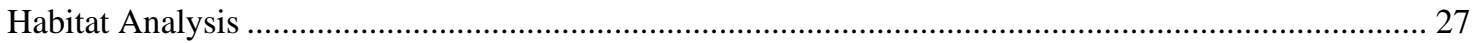

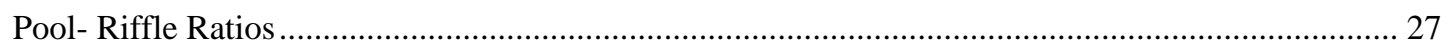

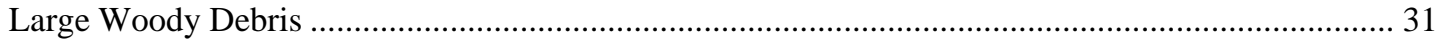

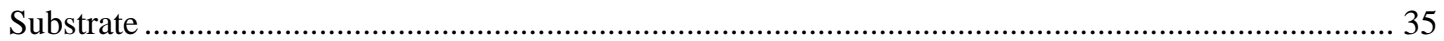

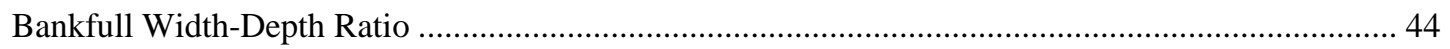

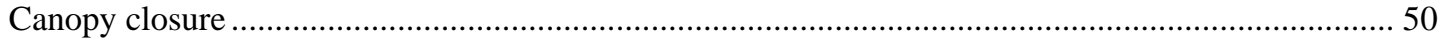

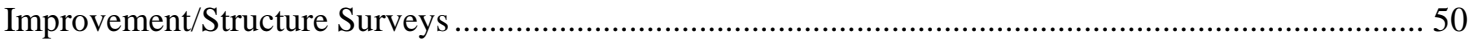

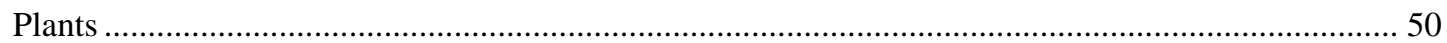

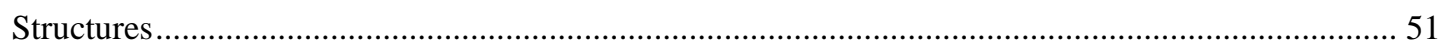

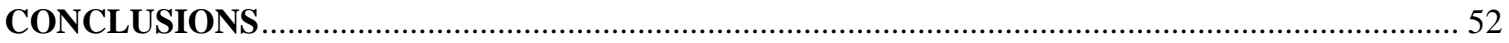

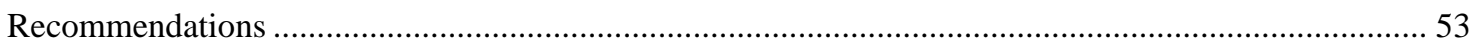

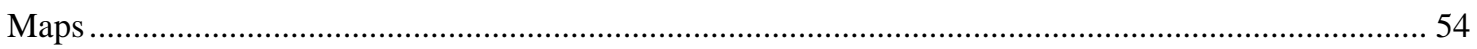

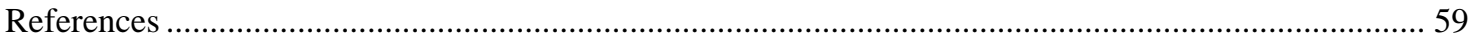




\section{ABSTRACT \\ Lake Roosevelt Rainbow Trout Habitat/Passage Improvement Project}

Lake Franklin D. Roosevelt was created with the completion of the Grand Coulee Dam in 1942. The lake stretches 151 miles up-stream to the International border between the United States and Canada at the 49th parallel. Increased recreational use, subsistence and sport fishing has resulted in intense interest and possible exploitation of the resources within the lake.

Previous studies of the lake and its fishery have been limited. Early studies indicate that natural reproduction within the lake and tributaries are not sufficient to support a rainbow trout (Onchoryhnchus mykiss) fishery (Scholz et. al., 1988). These studies indicate that the rainbow trout population may be limited by lack of suitable habitat for spawning and rearing (Scholz et. al., 1988).

The initial phase of this project (Phase I, baseline data collection- 1990-91) was directed at the assessment of limiting factors such as quality and quantity of available spawning gravel, identification of passage barriers, and assessment of other limiting factors. Population estimates were conducted using the Seber/LeCren removal/depletion method. After the initial assessment of stream parameters, several streams were selected for habitat/passage improvement projects (Phase II, implementation-1992-96). At the completion of project habitat improvements, the final phase (Phase III, monitoring) began. This phase will assess changes and gauge the success achieved through the improvements.

The objective of the project is to correct passage barriers and improve habitat conditions of selected tributaries to Lake Roosevelt for adfluvial rainbow trout that utilize tributary streams for spawning and rearing. Streams with restorable habitats were selected for improvements. Completion of improvement efforts should increase the adfluvial rainbow trout contribution to the resident fishery in Lake Roosevelt.

Three co-operating agencies, the Confederated Tribes of the Colville Reservation (CCT), the Spokane Tribe of Indians (STI) and the Washington Department of Fish and Wildlife initiated the project fieldwork in 1990. Phase II included only the Confederated Tribes of the Colville Reservation and the Spokane Tribe of Indians. Phase III is being completed by the Confederated Tribes of the Colville Reservation. 


\section{EXECUTIVE SUMMARY}

The Lake Roosevelt Rainbow Trout Habitat/Passage Improvement Project is a mitigation project intended to partially mitigate for Fish and Wildlife losses suffered because of the construction of Grand Coulee Dam. Four streams on the Colville Indian Reservation and one on the Spokane Indian Reservation were selected: South Nanamkin, North Nanamkin, Louie and Iron Creeks on the Colville Reservation, and Blue Creek on the Spokane Reservation.

Several studies were developed to design structures and meanders. Improvements included instream habitat structures, culvert replacements, fencing, meander reconstruction, bank stabilization, riparian plantings, and an irrigation water diversion repair. Over a time period of approximately four years these improvements/enhancements were installed. After the improvements were done, monitoring started which includes, on an annual basis, juvenile and adult trapping, juvenile population estimates, and habitat inventory.

This report includes data and analysis of the current year and multiple year comparisons/statistical analysis of data. Analysis is presented on habitat (pool/riffle ratios, large woody debris, substrate etc.), fish population estimates, stream flow data, significance of the results and success/failure of structures and data collection methods. The two sets of hypotheses for testing are:

1. The treatments (passage improvements) are effective for increasing the population of rainbow trout. 1a. The treatments (passage improvements) are not effective for increasing the population of rainbow trout. 2. The treatments (habitat improvements) are effective (e.g. pool-riffle ratios) for improving habitat in $\mathrm{X}$ stream.

2a. The treatments (habitat improvements) are not effective (e.g. pool-riffle ratios) for improving habitat in $\mathrm{X}$ stream.

Results show that while the increased habitat availability has probably improved the quantity of fish for recruitment to Lake Roosevelt and the San Poil River Basin, some of the data collection methods to detect these changes are not all adequate or possible due to fluctuations in water flow (extreme low and high). Three reaches that prior to 1996 had no fish present, due to manmade fish barriers, had a direct improvement since fish are now present and spawn in these reaches (highest reach of North Nanamkin, Iron and Blue Creeks). In all streams the fish population density has increased in pools and riffles in 1998 and 1999 compared to 1990 and 1991. It is estimated that the structures, fencing and riparian restoration has had at least some positive effects, but increased flow regimes in recent years may contribute to these increased densities (except for the three reaches previously mentioned, which received $100 \%$ success through passage improvements). The pool-riffle ratios vary from year to year and are difficult to judge when examining structures; some structures were buried the first year and reappeared this last year. It does appear that some stabilization has occurred, but long term monitoring would be the only way to assess the stabilization desired.

During 2000 the project biologist left the Tribes for a planning position in Wenatchee data was collected on Iron, Louie, North Nanamkin, and South Nanamkin creeks. Juvenile trapping and adult migratory trapping was conducted. Traps were installed at the end of February and removed on June 1, 2000. Habitat surveys were conducted on North and South Nanamkin and scales were read to determine age structure. Project proposal process approved the planned habitat and passage improvements proposed for Bridge Creek. The work on Bridge Creek is scheduled to begin in 2001 and continue through 2004. 


\section{INTRODUCTION}

\section{HISTORICAL BACKGROUND}

Since the loss of anadromous salmonids above Grand Coulee Dam, fishery enhancement measures have been limited on the reservoir. A few short-term fisheries surveys were conducted on the reservoir along with the introduction of fish species by the Washington Department of Fish and Wildlife (WDFW), Spokane Tribe of Indians (STI), and the Confederated Tribes of the Colville Reservation (CCT). Studies have shown that existing spawning habitat in Lake Roosevelt tributary streams may be inadequate to sustain a rainbow trout (Oncorhynchus mykiss) fishery in Lake Roosevelt (Scholz et. al., 1988). Upstream migration passage barriers limit the amount of spawning and rearing habitat that might otherwise be utilized by rainbow trout. Limited stream surveys and habitat inventories indicate that a potential for increased natural production exists. The lack of any comprehensive enhancement measures prompted the Upper Columbia United Tribes Fisheries Center (UCUT), Colville Confederated Tribes (CCT), Spokane Tribe of Indians (STI) and Washington Department of Fish and Wildlife (WDFW) to develop a comprehensive fishery management plan for Lake Roosevelt (Scholz et. al., 1988). The Rainbow Trout Habitat/Passage Improvement Project (LRHIP) was designed with goals directed towards increasing natural production while maintaining genetic integrity among current tributary stocks.

The plan was amended into the Columbia River Basin Fish and Wildlife Program by the Northwest Power Planning Council (NPPC) in 1987 (NPPC, 1987). Program Measures 903 (g) (1)(c)(d)(e) directed Bonneville Power Administration (BPA) to fund "improvement of spawning and rearing habitat in order to facilitate passage to spawning tributaries to increase natural production of rainbow trout" and "evaluate the effectiveness of the above measures by conducting a monitoring program".

The interagency team of the Colville Confederated Tribes (CCT), Spokane Tribe of Indians (STI), Washington Department of Wildlife (WDW), and the Upper Columbia United Tribes (UCUT) selected the streams for habitat evaluation.

\section{DESCRIPTION OF STUDY AREA}

Lake Franklin D. Roosevelt reaches upstream from the Grand Coulee Dam, 151 miles to the Canadian border. Approximately 494 miles of shoreline exist where sixty-five (65) tributary streams contribute their flow and biomass to the fishery in the lake. Ferry, Stevens, Spokane, Lincoln, Grant and Okanogan Counties border the shoreline and study areas. The area lies within the Okanogan Highland geological district. The land habitat surrounding this lake is diverse, habitats range from coniferous forest, lush lowlands to semi-arid shrub steppe. Annual rainfall regimes (10 inches/year at low elevation, to 35 at the highest elevation) greatly affect the climate of the area. Annual temperatures range from winter lows of -40 degrees $\mathrm{F}$. to summer highs of $100+\mathrm{F}$.

During earlier historic periods this area hosted vast numbers of salmon returning to their natal waters to reproduce and die. Salmon and steelhead provided sustenance, the religious focus and cultural basis of the native people of the region. In death, their decaying carcasses provided untold amounts of nutrients re-cycled into the ecosystem.

Near the present site of Kettle Falls, WA. the second largest Indian fishery in the state existed for thousands of years. Returning salmon were caught in nets, baskets or speared on their migration to the headwater of the Columbia River in British Columbia. Other lesser, but important, fishery sites existed south of Kettle Falls at Rickey Rapids and at the Little Spokane Falls. Catch estimates at Kettle Falls range from 600,000 in 1940 to 1-2 million around the turn of the century (UCUT, Report \#2).

Annual gatherings at the various fishing sites brought together many bands of native people for fishing, socializing and religious activities. The rumble of the great Kettle Falls could be heard from as far away as 10 miles (UCUT, Rep \#2). The roar of the falls was silenced forever in 1943 when the backwaters of Grand Coulee Dam inundated the falls. Lost forever to the native people of the area and all other region residents were the diversity of the salmon runs, economy to the area, nutrient contribution to the upper Columbia area, religious significance of and the culture linked to vast salmon runs. Historians generally agree that by the turn of the century, the once limitless runs were beginning to decline due to the intense salmon fishery on the lower Columbia near Portland OR. (UCUT, Report \#2). 


\section{SCOPE OF PROJECT}

\section{OBJECTIVE}

The objective of all three phases is to enhance and protect the natural spawning adfluvial rainbow trout of Lake Roosevelt. A habitat passage improvement plan was developed using the data collected by field teams from the two co-operating agencies; the Colville Confederated Tribes (CCT) and the Spokane Tribe of Indians (STI). Projects that will remove passage barriers, reduce sediment loading, improve or protect existing riparian vegetation, provide habitat diversity and protect the genetic integrity of rainbow trout within the system will be prioritized for implementation.

\section{GOAL}

The goal of this project is to increase the quality and quantity of rainbow trout spawning and rearing habitat available to adfluvial rainbow trout with an emphasis on increasing the survival of wild and/or natural stocks. This goal will be achieved by protecting and improving the habitat of the stocks indigenous to Lake Roosevelt. Ultimately, this will increase the contribution of adfluvial rainbow trout to the fishery in the lake. Stream improvements were accomplished using established methodologies (Hunter, 1991; Rosgen, 1986; Wesche, 1985) and through training from Dr. Donald R. Reichmuth, Dr. David Rosgen, Dr. John Orsborn P.E. and a fish habitat management short course at Utah State University (multiple educators). Improvements included removal of passage barriers, realignment of stream channel, resetting of culverts, re-establishment of stream meanders, and addition of log stump, rootwad and boulder structures in selected streams. Some streams only had a culvert re-installed on grade to eliminate a passage barrier. Others required the use of several structures to create better habitat and diversity. Finally, the project utilizes TFW ambient monitoring methodologies to monitor and evaluate the effects of improvements on all physical and biological parameters enumerated during the course of the project. Collection of baseline data includes classification and enumeration of various stream parameters and also includes riparian vegetation, fish population estimates, biomass and densities.

\section{MONITORING/METHODS}

The first spring season following the completion of the implementation phase (1997), the project began the monitoring phase. The monitoring phase is conducted using the same methodologies as before implementation (TFW ambient monitoring, population estimates). Follow up monitoring will be only conducted on streams where habitat/passage improvements were installed. In addition to employing the ambient monitoring methods, an assessment of the number of returning adfluvial rainbow trout spawners is completed annually. Out-migrating juvenile rainbow trout numbers is also conducted in conjunction with the adult enumeration. Adult spawner enumeration will be done using a picket fence type of trap at the mouths of the streams. Other methods will include foot surveys and redd counts. Out-migrating juvenile assessments are completed using fyke type net traps with a holding box. Traps are maintained daily. The time frame for the monitoring phase will run through the year 2000. The annual and final reports will evaluate the effectiveness of the implementation efforts. 


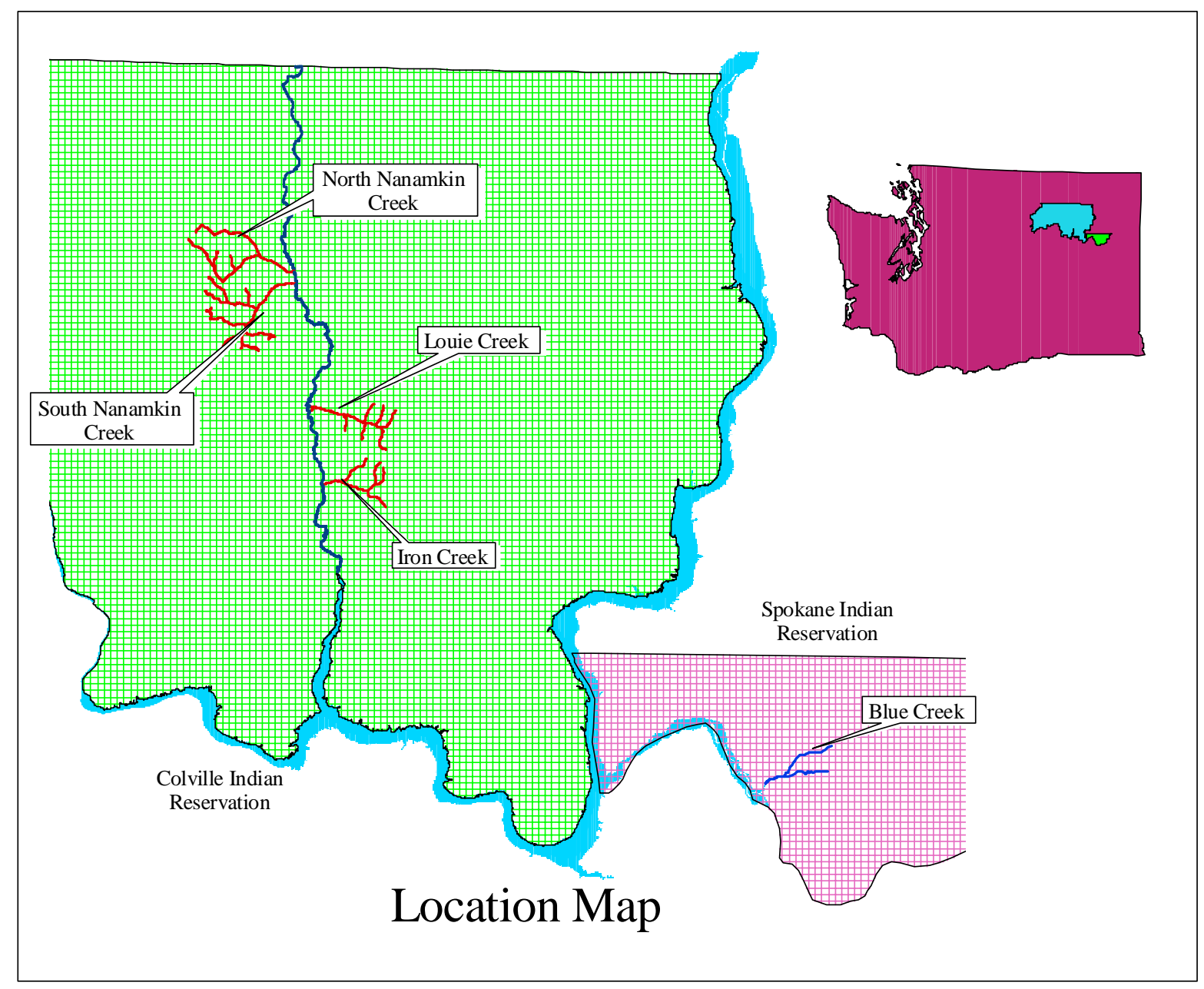

\section{RESULTS}

The fish trapping data collection in most years were incomplete for two reasons. During spring high flows prevented data collection equipment from operating correctly throughout the fish trapping period. The velocity, bedload movement and turbidity prevented data collection for short periods of time; technicians could not enter the streams without high risk. The remainder of the data collection occurred during late summer-fall. Below are summary tables of data collected in each year and maps of original valley segments in 1990-1991.

Table 1. Adult Trapping Data, 2000 (length in millimeters, weight in grams).

\begin{tabular}{|l|c|c|c|c|c|c|c|c|}
\hline \multicolumn{1}{|c|}{ Stream } & $\begin{array}{c}\text { \# of } \\
\text { Adults }\end{array}$ & $\begin{array}{c}\text { Sex } \\
\text { Ratio } \\
\text { M/F }\end{array}$ & $\begin{array}{c}\text { Ave. } \\
\text { Weight }\end{array}$ & $\begin{array}{c}\text { Max } \\
\text { Weight }\end{array}$ & $\begin{array}{c}\text { Min } \\
\text { Weight }\end{array}$ & $\begin{array}{c}\text { Ave. } \\
\text { Length }\end{array}$ & $\begin{array}{c}\text { Max } \\
\text { Length }\end{array}$ & $\begin{array}{c}\text { Min } \\
\text { Length }\end{array}$ \\
\hline Iron & 45 & $17 / 28$ & 1017.4 & 1425 & 484 & 450.8 & 505 & 345 \\
\hline Louie & 55 & $33 / 22$ & 947.5 & 1450 & 275 & 449.7 & 535 & 334 \\
\hline $\begin{array}{l}\text { North } \\
\text { Nanamkin }\end{array}$ & 38 & $20 / 18$ & 1023.4 & 1550 & 94 & 442.3 & 530 & 200 \\
\hline $\begin{array}{l}\text { South } \\
\text { Nanamkin }\end{array}$ & 15 & $6 / 9$ & 1006.4 & 1343 & 545 & 446.1 & 487 & 378 \\
\hline Total/Avg. & 153 & $76 / 77$ & 998.7 & 1442.0 & 349.5 & 447.2 & 514.3 & 314.3 \\
\hline
\end{tabular}


Table 2. Adult Trapping Data, 1999 (length in millimeters, weight in grams).

\begin{tabular}{|l|l|l|l|l|l|l|l|l|}
\hline \multicolumn{1}{|c|}{ Stream } & $\begin{array}{c}\text { \# of } \\
\text { Adults }\end{array}$ & $\begin{array}{c}\text { Sex } \\
\text { Ratio M/F }\end{array}$ & $\begin{array}{c}\text { Ave. } \\
\text { Weight }\end{array}$ & $\begin{array}{c}\text { Max } \\
\text { Weight }\end{array}$ & $\begin{array}{c}\text { Min } \\
\text { Weight }\end{array}$ & $\begin{array}{c}\text { Ave. } \\
\text { Length }\end{array}$ & $\begin{array}{c}\text { Max } \\
\text { Length }\end{array}$ & $\begin{array}{c}\text { Min } \\
\text { Length }\end{array}$ \\
\hline Iron Creek & 5 & $2 / 3$ & 989.5 & 1089 & 877 & $416^{*}$ & 490 & $220^{*}$ \\
\hline & & & & & & 465 & 490 & 442 \\
\hline Louie Creek & 11 & $7 / 4$ & 997.9 & 1263 & 636 & 449.6 & 543 & 390 \\
\hline North Nanamkin & 32 & $16 / 16$ & 937.6 & 1460 & 202 & 445.7 & 540 & 256 \\
\hline South Nanamkin & 11 & $5 / 6$ & 854.2 & 1478 & 193 & 418.5 & 511 & 257 \\
\hline Total & $\mathbf{5 9}$ & $30 / 29$ & 936.8 & 1478 & 193 & 438.6 & 543 & 220 \\
\hline
\end{tabular}

*The $220 \mathrm{~mm}$ fish was not weighed so the weight statistics do not include that fish. The values in the second row match the fish weighed in the first row.

Table 3. Adult Trapping Data, 1998.

\begin{tabular}{|l|l|l|l|l|l|l|l|l|}
\hline Stream & $\begin{array}{l}\text { \# of } \\
\text { Adults }\end{array}$ & $\begin{array}{l}\text { Sex } \\
\text { Ratio M/F }\end{array}$ & $\begin{array}{l}\text { Ave. } \\
\text { Weight }\end{array}$ & $\begin{array}{l}\text { Max } \\
\text { Weight }\end{array}$ & $\begin{array}{l}\text { Min } \\
\text { Weight }\end{array}$ & $\begin{array}{l}\text { Ave. } \\
\text { Length }\end{array}$ & $\begin{array}{l}\text { Max } \\
\text { Length }\end{array}$ & $\begin{array}{l}\text { Min } \\
\text { Length }\end{array}$ \\
\hline Blue Creek & No Data & & & & & & & \\
\hline Iron Creek & 9 & $5 / 4$ & 1115 & 1430 & 524 & 459 & 525 & 301 \\
\hline Louie Creek & 9 & $5 / 4$ & 1481 & 1758 & 1028 & 510 & 585 & 458 \\
\hline North Nanamkin & 19 & $7 / 12$ & 1342 & 1724 & 1105 & 498 & 546 & 470 \\
\hline South Nanamkin & 0 & & & & & & & \\
\hline Total & $\mathbf{3 7}$ & $17 / 20$ & 1312.7 & 1637.3 & 885.7 & 489.0 & 552.0 & 409.7 \\
\hline
\end{tabular}

Table 4. Adult Trapping Data, 1997.

\begin{tabular}{|l|l|l|l|l|l|l|l|l|}
\hline Stream & \# of Adults & $\begin{array}{l}\text { Sex } \\
\text { Ratio M/F }\end{array}$ & $\begin{array}{l}\text { Ave. } \\
\text { Weight }\end{array}$ & $\begin{array}{l}\text { Max } \\
\text { Weight }\end{array}$ & $\begin{array}{l}\text { Min } \\
\text { Weight }\end{array}$ & $\begin{array}{l}\text { Ave. } \\
\text { Length }\end{array}$ & $\begin{array}{l}\text { Max } \\
\text { Length }\end{array}$ & $\begin{array}{l}\text { Min } \\
\text { Length }\end{array}$ \\
\hline Blue Creek & No Data & & & & & & & \\
\hline Iron Creek & 1 & $1 / 0$ & & & & 454 & 454 & 454 \\
\hline Louie Creek & No Data & & & & & & & \\
\hline North Nanamkin & 12 & $10 / 2$ & 822 & 1928 & 490 & 459 & 540 & 395 \\
\hline South Nanamkin & No Data & & & & & & & \\
\hline Total & $\mathbf{1 3}$ & & 822 & 1928 & 490 & 156.5 & 497.0 & 424.5 \\
\hline
\end{tabular}

Table 5. Adult Trapping Data, 1996.

\begin{tabular}{|l|l|l|l|l|l|l|l|l|}
\hline Stream & \# of Adults & $\begin{array}{l}\text { Sex } \\
\text { Ratio M/F }\end{array}$ & $\begin{array}{l}\text { Ave. } \\
\text { Weight }\end{array}$ & $\begin{array}{l}\text { Max } \\
\text { Weight }\end{array}$ & $\begin{array}{l}\text { Min } \\
\text { Weight }\end{array}$ & $\begin{array}{l}\text { Ave. } \\
\text { Length }\end{array}$ & $\begin{array}{l}\text { Max } \\
\text { Length }\end{array}$ & $\begin{array}{l}\text { Min } \\
\text { Length }\end{array}$ \\
\hline Blue Creek & 4 & $4 / 0$ & 738 & 1589 & 77 & 363 & 526 & 193 \\
\hline Iron Creek & 5 & $2 / 3$ & 1317 & 1589 & 1135 & 489 & 521 & 450 \\
\hline Louie Creek & 3 & $3 / 0$ & 1052 & 1203 & 908 & 495 & 521 & 483 \\
\hline North Nanamkin & 25 & $11 / 14$ & 1159 & 1657 & 477 & 491 & 546 & 343 \\
\hline South Nanamkin & 2 & $0 / 2$ & 1226 & 1294 & 1158 & 537 & 541 & 533 \\
\hline Total & $\mathbf{3 9}$ & $20 / 19$ & 1098.4 & 1466.4 & 751 & 475 & 531 & 400.4 \\
\hline
\end{tabular}

Table 6. Adult Trapping Data, 1995.

\begin{tabular}{|l|l|l|l|l|l|l|l|l|}
\hline Stream & \# of Adults & $\begin{array}{l}\text { Sex } \\
\text { Ratio M/F }\end{array}$ & $\begin{array}{l}\text { Ave. } \\
\text { Weight }\end{array}$ & $\begin{array}{l}\text { Max } \\
\text { Weight }\end{array}$ & $\begin{array}{l}\text { Min } \\
\text { Weight }\end{array}$ & $\begin{array}{l}\text { Ave. } \\
\text { Length }\end{array}$ & $\begin{array}{l}\text { Max } \\
\text { Length }\end{array}$ & $\begin{array}{l}\text { Min } \\
\text { Length }\end{array}$ \\
\hline Blue Creek & No Data & & & & & & & \\
\hline Iron Creek & 35 & & & & & & & \\
\hline Louie Creek & 11 & & No Data & & & & & \\
\hline North Nanamkin & 111 & & & & & & & \\
\hline South Nanamkin & 57 & & & & & & & \\
\hline Total & $\mathbf{2 1 4}$ & & & & & & & \\
\hline
\end{tabular}


Table 7. Adult Trapping Data, 1994.

\begin{tabular}{|l|l|l|l|l|l|l|l|l|}
\hline Stream & \# of Adults & $\begin{array}{l}\text { Sex } \\
\text { Ratio M/F* }\end{array}$ & $\begin{array}{l}\text { Ave. } \\
\text { Weight }\end{array}$ & $\begin{array}{l}\text { Max } \\
\text { Weight }\end{array}$ & $\begin{array}{l}\text { Min } \\
\text { Weight }\end{array}$ & $\begin{array}{l}\text { Ave. } \\
\text { Length }\end{array}$ & $\begin{array}{l}\text { Max } \\
\text { Length }\end{array}$ & $\begin{array}{l}\text { Min } \\
\text { Length }\end{array}$ \\
\hline Blue Creek & No Data & & & & & & & \\
\hline Iron Creek & 37 & $7 / 7$ & & & & 526 & 584 & 444 \\
\hline Louie Creek & 17 & & & & & & & \\
\hline North Nanamkin & 124 & $47 / 64$ & 1335 & 2270 & 341 & 505 & 660 & 279 \\
\hline South Nanamkin & 68 & $33 / 19$ & 1380 & 1816 & 681 & 508 & 610 & 356 \\
\hline Total & $\mathbf{2 4 6}$ & $87 / 90$ & 1357.5 & 2043.0 & 511.0 & 513.0 & 618.0 & 359.7 \\
\hline
\end{tabular}

*Not all of the fish had data taken or data was lost (applies to 1995 as well).

\section{Discussion and trends in adult trapping}

The data from the adult trapping was assembled as depicted in Chart 1, and shows that there may be a relationship of returning fish and the annual drawdown on Lake Roosevelt. Data from 1994 through 1999 was analyzed using regression, but the relationship was not a strong one for the full range of years (r square 0.54). The data from 1998 is an outlier, but it is unknown why. Note that the comparisons to Lake Roosevelt drawndowns may, in fact, be a surrogate to annual precipitation events and/or changes (trapping efficiency drops in high precipitation years, which are also deep drawdown years). Removing the 1998 data set, the relationship becomes much stronger ( $\mathrm{r}$ square 0.92 ). The data set is probably not over a long enough period of time to determine success in the overall project in terms of adult recruitment. The returning fish average three to four years in age, and 1999 would be the first possible year that adults would be returning to spawn since all the improvements were finished. There was a gain in the number of fish trapped in 1999, but not above the 1994 or 1995 counts. Examining individual streams Iron Creek had the strongest $r$ square (0.73), but Iron had very low annual numbers (in 1997 only one fish was caught). North and South Nanamkin have r square values of 0.48 and 0.50 respectively, and Louie Creek at 0.46. Without the 1998 data the r square is stronger (Iron 0.93, Louie 0.57, North Nanamkin 0.93 and South Nanamkin 0.90). There is no apparent reason for Louie Creek having a low $r$ square.

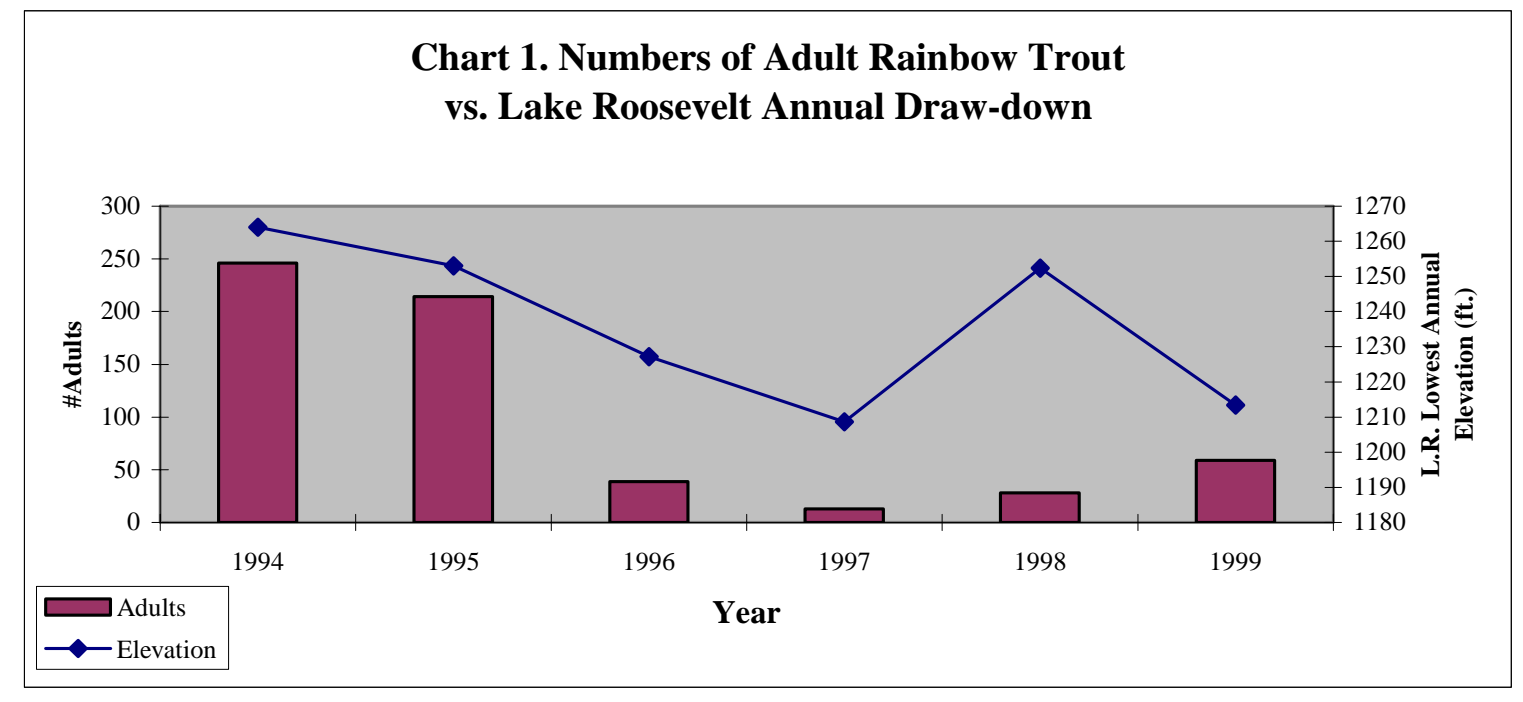

Analysis was also done comparing Lake Roosevelt low elevation three and four years prior to the adult return. Using a three and four year delay the charts and regression look much different (Chart 1 and 2). 

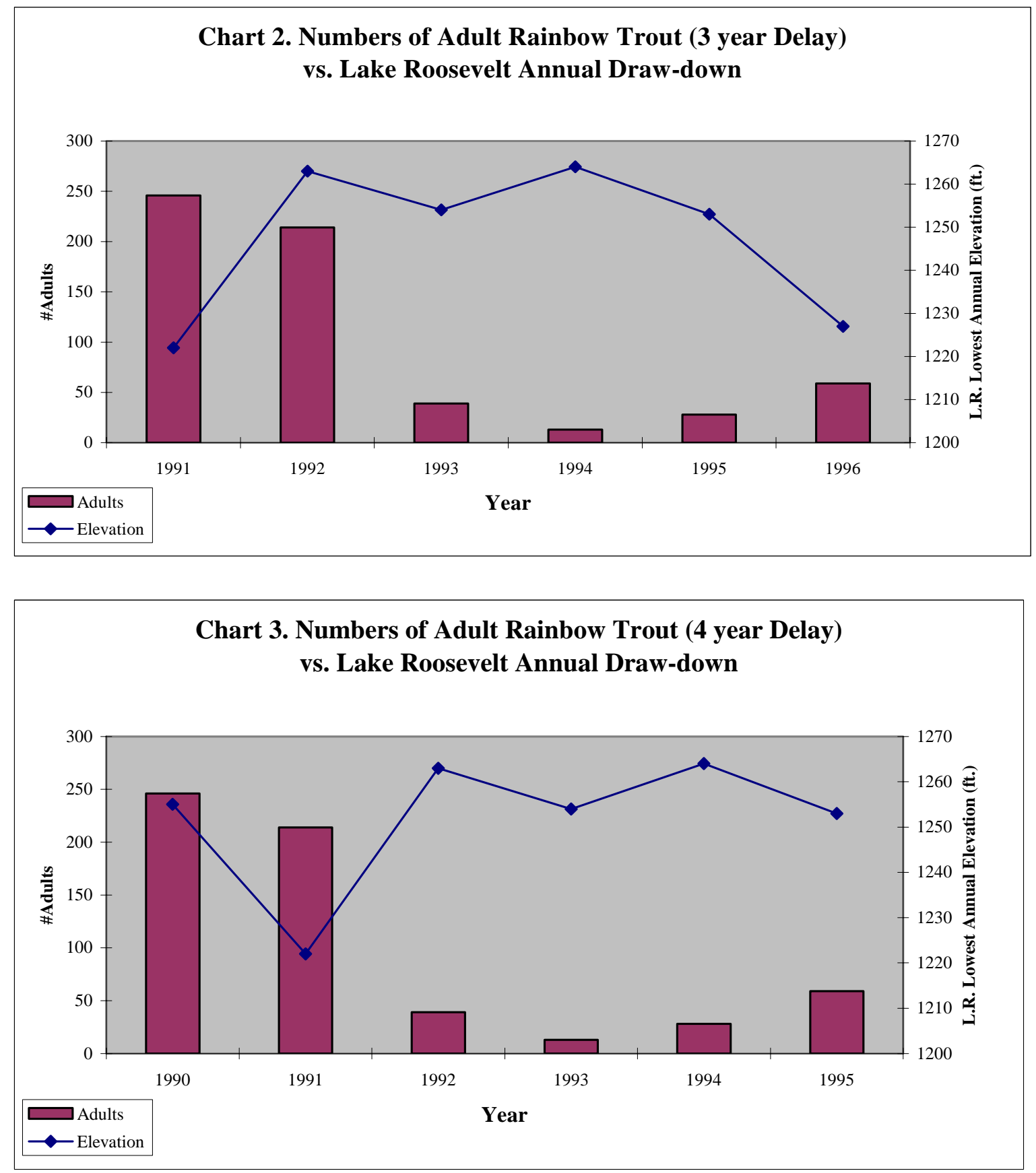


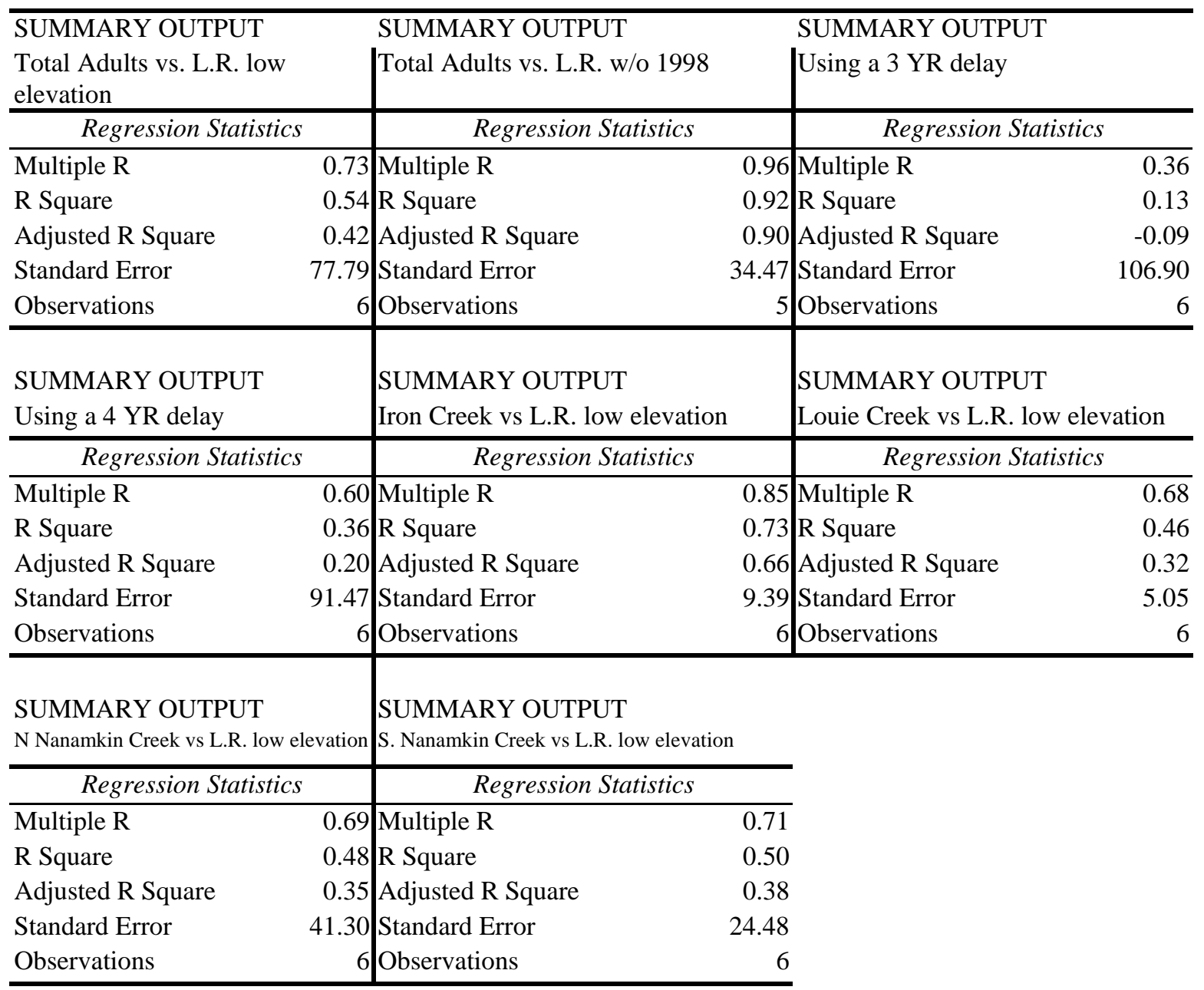

\begin{tabular}{|c|c|c|c|}
\hline $\begin{array}{l}\text { SUMMARY OUTPUT } \\
\text { Iron Creek vs L.R. low elevation }\end{array}$ & & \multicolumn{2}{|c|}{$\begin{array}{l}\text { SUMMARY OUTPUT } \\
\text { Louie Creek vs L.R. low elevation }\end{array}$} \\
\hline \multicolumn{2}{|l|}{ Regression Statistics } & \multicolumn{2}{|c|}{ Regression Statistics } \\
\hline Multiple R & 0.97 & Multiple R & 0.76 \\
\hline R Square & 0.93 & R Square & 0.57 \\
\hline Adjusted R Square & 0.91 & Adjusted R Square & 0.43 \\
\hline Standard Error & 5.30 & Standard Error & 5.17 \\
\hline Observations & 5 & Observations & 5 \\
\hline $\begin{array}{l}\text { SUMMARY OUTPUT } \\
\text { N Nanamkin Creek vs L.R. low elevation }\end{array}$ & & $\begin{array}{l}\text { SUMMARY OUTF } \\
\text { S. Nanamkin Creek vs L }\end{array}$ & \\
\hline \multicolumn{2}{|l|}{ Regression Statistics } & \multicolumn{2}{|c|}{ Regression Statistics } \\
\hline Multiple R & 0.96 & Multiple R & 0.95 \\
\hline R Square & 0.93 & R Square & 0.90 \\
\hline Adjusted R Square & 0.90 & Adjusted R Square & 0.86 \\
\hline Standard Error & 16.17 & Standard Error & 11.96 \\
\hline Observations & 5 & Observations & 5 \\
\hline
\end{tabular}


Statistics- Adult Return to Lake Roosevelt Drawdown Elevation ---Without the 1998 data---

The rainbow trout captured during migration during the trapping period were aged each year using a microfiche reader. Scales were only available for years 1996, 1998, and 1999 (see Table 4). The total sample of 94 fish for the three years had 37 males and 57 females. The higher number of females is not consistent for every stream, and the best possible explanation is that males tend to be smaller and may get through the trap bars on occasion. Blue Creek has had no adult trapping since 1996, and no scales were available for aging from any year. Females are older, averaging 6 months in age older. This age difference is probably due to the time for gonadal development in females versus males.

Table 4. Adult Rainbow Trout Age- Data Summary.

\begin{tabular}{|c|c|c|c|c|}
\hline & \multicolumn{2}{|c|}{ Total sampled } & Sample by sex & Average Age \\
\hline 1996 AVERAGE & & 24 & & 4.0 \\
\hline Males (=M) & & & 2 & 4.0 \\
\hline Females (=F) & & & 16 & 4.2 \\
\hline 1998 AVERAGE & & 35 & & 4.5 \\
\hline Males (=M) & & & 17 & 4.2 \\
\hline Females $(=F)$ & & & 17 & 4.8 \\
\hline & & & & \\
\hline 1999 AVERAGE & & 43 & & 3.9 \\
\hline Males (=M) & & & 19 & 3.5 \\
\hline Females (=F) & & & 24 & 4.1 \\
\hline 2000 AVERAGE & & 97 & & 4.9 \\
\hline Males (=M) & & & 55 & 4.5 \\
\hline Females (=F) & & & 42 & 5.0 \\
\hline ALL YEARS & Count & & VARIANCE & STD DEV \\
\hline AVERAGE & & 4.3 & 1.02 & 1.01 \\
\hline Males (=M) & 93 & 4.1 & 0.76 & 0.87 \\
\hline Females $(=F)$ & 99 & 4.5 & 1.07 & 1.04 \\
\hline Total & 192 & & & \\
\hline
\end{tabular}

Table 5. Age Structure of Fish Captured in 2000

\begin{tabular}{|c|c|c|}
\hline Age & Females & Males \\
\hline 3 & 0 & 3 \\
\hline 4 & 7 & 25 \\
\hline 5 & 21 & 21 \\
\hline 6 & 11 & 3 \\
\hline 7 & 3 & 3 \\
\hline
\end{tabular}




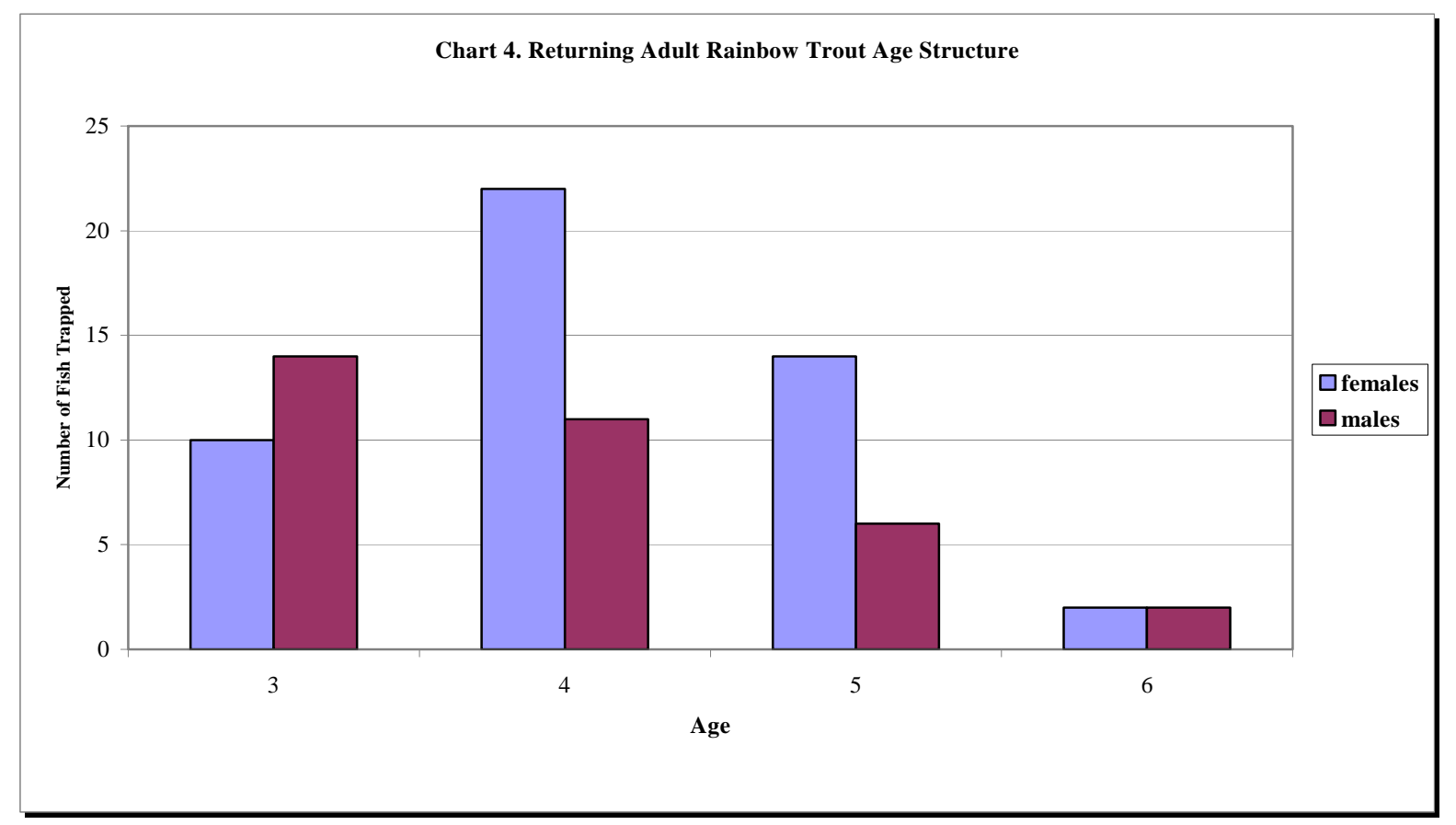

Length and weight were analyzed using regression as well, but the r square was only a 0.595 at a $95 \%$ confidence interval (see results below).

\section{SUMMARY OUTPUT}

\section{Length and Weight}

\begin{tabular}{lc}
\hline \multicolumn{2}{c}{ Regression Statistics } \\
\hline Multiple R & 0.771 \\
R Square & 0.595 \\
Adjusted R Square & 0.590 \\
Standard Error & 30.006 \\
Observations & 86 \\
\hline
\end{tabular}

\section{Discussion and trends in juvenile trapping}

The number of fish trapped has steadily gone up every year since 1996, except for 1997 (see tables 4 through 7). The spring spates of 1997 were so severe that the some of the traps were destroyed and could not be rebuilt before the season ended. Again this analysis considers the data as an aggregate of the streams and not any individual stream. This was done to even out any problems during trapping in any one year at any one stream. For example, at Iron Creek the trap caught less fish in 1999 versus 1998 and is probably due to flooding damage from logging practices in the Iron Creek drainage; South Nanamkin Creek was not sampled in much of 1998 (unknown reason). The average length/weight of YOY juveniles seen in streams was smaller in the trapping in 1999 compared to other years, but it is unknown why. Lake Roosevelt low elevation (as a surrogate to stream flow peaks) was compared to the number trapped, but the $\mathrm{r}$ square was very low at 0.07 (Chart 5). The juveniles trapped were also compared to the adults trapped in the same year (Chart 6). This assumes that most of the juveniles were young of the year (which they appear to be). The $r$ square for this was 0.69 at a $95 \%$ confidence interval. 
Table 5. Juvenile Rainbow Trout Trapping Data, 2000 (length in millimeters, weight in grams).

\begin{tabular}{|l|c|c|c|c|}
\hline Stream & \# of fish & $\begin{array}{l}\text { Ave. } \\
\text { Length }\end{array}$ & $\begin{array}{l}\text { Max. } \\
\text { Length }\end{array}$ & $\begin{array}{l}\text { Min. } \\
\text { Length }\end{array}$ \\
\hline Iron Creek & 125 & 67.1 & 115 & 35 \\
\hline Louie Creek & 291 & 67.7 & 115 & 10 \\
\hline North Nanamkin & 186 & 79.3 & 210 & 40 \\
\hline South Nanamkin & 35 & 66.5 & 88 & 40 \\
\hline Total/Average & $\mathbf{6 3 7} *$ & 70.2 & 132 & 31.3 \\
\hline
\end{tabular}

* One YOY was captured in Louie Creek 636 were $1+$ years

Table 6. Juvenile Rainbow Trout Trapping Data, 1999 (length in millimeters, weight in grams).

\begin{tabular}{|l|c|l|l|l|l|l|l|}
\hline Stream & \# of fish & $\begin{array}{l}\text { Ave. } \\
\text { Weight }\end{array}$ & $\begin{array}{l}\text { Max. } \\
\text { Weight }\end{array}$ & $\begin{array}{l}\text { Min. } \\
\text { Weight }\end{array}$ & $\begin{array}{l}\text { Ave. } \\
\text { Length }\end{array}$ & $\begin{array}{l}\text { Max. } \\
\text { Length }\end{array}$ & $\begin{array}{l}\text { Min. } \\
\text { Length }\end{array}$ \\
\hline Iron Creek & 92 & 0.3 & 2.7 & 0.1 & 25.3 & 66 & 15 \\
\hline Louie Creek & 132 & 2.1 & 36.8 & 0.1 & 45.9 & 148 & 15 \\
\hline North Nanamkin & 214 & 1.3 & 6.1 & 0.1 & 38.7 & 87 & 20 \\
\hline South Nanamkin & 59 & 3.2 & 75.4 & 0.1 & 43.8 & 202 & 20 \\
\hline Total & $\mathbf{4 9 7}$ & $\begin{array}{l}307 \text { were } \\
\text { YOY }\end{array}$ & & & & & \\
\hline
\end{tabular}

Table 5. Juvenile Rainbow Trout Trapping Data, 1998.

\begin{tabular}{|l|l|l|l|l|l|l|l|}
\hline Stream & \# of fish & $\begin{array}{l}\text { Ave. } \\
\text { Weight }\end{array}$ & $\begin{array}{l}\text { Max. } \\
\text { Weight }\end{array}$ & $\begin{array}{l}\text { Min. } \\
\text { Weight }\end{array}$ & $\begin{array}{l}\text { Ave. } \\
\text { Length }\end{array}$ & $\begin{array}{l}\text { Max. } \\
\text { Length }\end{array}$ & $\begin{array}{l}\text { Min. } \\
\text { Length }\end{array}$ \\
\hline Blue Creek & No Data & & & & & & \\
\hline Iron Creek & 145 & 3.3 & 74 & 0.6 & 58 & 187 & 35 \\
\hline Louie Creek & 98 & 2.5 & 18 & 0.7 & 59 & 124 & 36 \\
\hline North Nanamkin & 96 & 2.3 & 7.4 & 0.5 & 56 & 96 & 35 \\
\hline South Nanamkin & No Data & & & & & & \\
\hline Total & $\mathbf{3 3 9}$ & & & & & & \\
\hline
\end{tabular}

Table 6. Juvenile Rainbow Trout Trapping Data, 1997.

\begin{tabular}{|l|l|l|l|}
\hline Stream & \# of fish & Ave Weight & Average Length \\
\hline Blue Creek & No Data & & \\
\hline Iron Creek & 10 & $8.5 \mathrm{~g}$ & $67.2 \mathrm{~mm}$ \\
\hline Louie Creek & No Data & & \\
\hline North Nanamkin & 2 & $6.0 \mathrm{~g}$ & $42.5 \mathrm{~mm}$ \\
\hline South Nanamkin & No Data & & \\
\hline Total & $\mathbf{1 2}$ & & \\
\hline
\end{tabular}

Table 7. Juvenile Rainbow Trout Trapping Data, 1996.

\begin{tabular}{|l|l|l|l|l|l|l|l|}
\hline Stream & \# of fish & $\begin{array}{l}\text { Ave. } \\
\text { Weight }\end{array}$ & $\begin{array}{l}\text { Max. } \\
\text { Weight }\end{array}$ & $\begin{array}{l}\text { Min. } \\
\text { Weight }\end{array}$ & $\begin{array}{l}\text { Ave. } \\
\text { Length }\end{array}$ & $\begin{array}{l}\text { Max. } \\
\text { Length }\end{array}$ & $\begin{array}{l}\text { Min. } \\
\text { Length }\end{array}$ \\
\hline Blue Creek & 31 & 20.2 & 68 & 2.3 & 119 & 193 & 63 \\
\hline Iron Creek & 93 & 3.5 & 15 & 1 & 66 & 108 & 39 \\
\hline Louie Creek & 19 & 2.7 & 6 & 2 & 58 & 78 & 50 \\
\hline North Nanamkin & 13 & 3.3 & 6 & 1 & 65 & 110 & 45 \\
\hline South Nanamkin & 7 & 3.3 & 8 & 1 & 72 & 102 & 57 \\
\hline Total & $\mathbf{1 6 3}$ & & & & & & \\
\hline
\end{tabular}




\begin{tabular}{lc}
\hline \multicolumn{2}{l}{ SUMMARY OUTPUT } \\
\multicolumn{2}{l}{ Juveniles and LR elevation } \\
\hline \multicolumn{2}{c}{ Regression Statistics } \\
\hline Multiple R & 0.27 \\
R Square & 0.07 \\
Adjusted R Square & -0.4 \\
Standard Error & 245 \\
Observations & 4 \\
\hline
\end{tabular}

SUMMARY OUTPUT

Juveniles vs. Adult returns

\begin{tabular}{lc}
\hline \multicolumn{2}{c}{ Regression Statistics } \\
\hline Multiple R & 0.83 \\
R Square & 0.69 \\
Adjusted R Square & 0.53 \\
Standard Error & 142 \\
Observations & 4 \\
\hline
\end{tabular}

\section{Chart 5. Juvenile Rainbow Trout Trapped 1996-1999 and Minimum Lake Roosevelt Elevation}
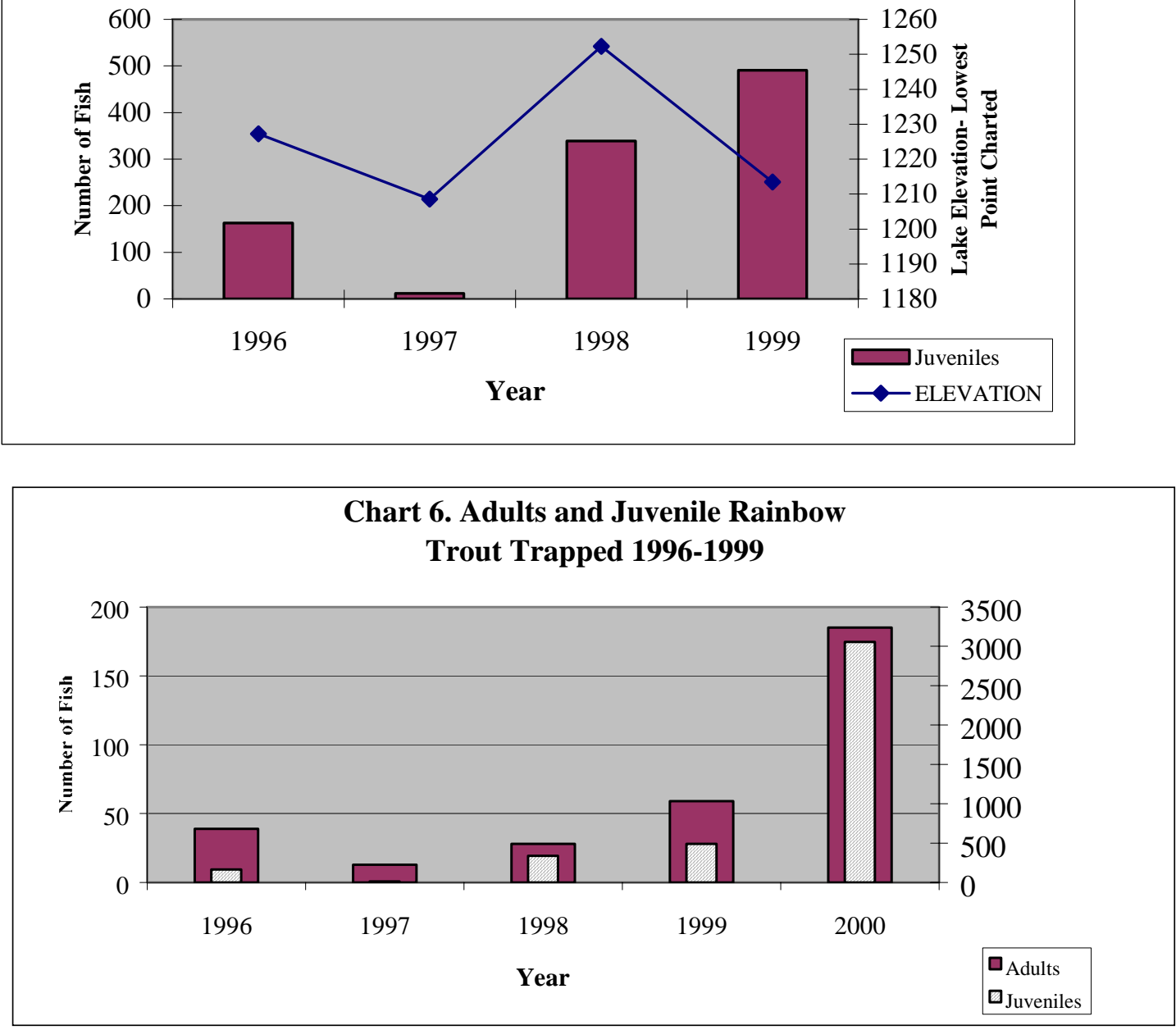

Screw Trap Data Analysis

A screw type trap has been used in conjunction with the Chief Joseph Kokanee Enhancement Project (BPA Project \#9501100). This methodology used, to assess juvenile emigration, a five foot diameter rotary screw trap made by E. G. Solutions. The trap was installed near the mouth of the San Poil River and fished for varying lengths of time dependant upon flow conditions. The trap was deployed in the thalweg of the stream. Project personnel checked the trap three times per day or more depending upon sampling success. 
The trap was used from 1996 through 1999 in the spring of the year: total days of trapping were 1996- 64, 1997-65, 1998- 40 and 1999- 28. The variance in days reflects the fact that the channel changed significantly in 1997 and made it difficult to employ the unit (debris jams, channel depth, large exposed boulders etc.) in latter years. Comparisons between the years has been done using the average fish per day (rate) instead of total fish caught (Chart 9). A length distribution for all four years has been done (Chart 7) and a comparison between sampling techniques as well (screw trap versus small project stream trapping units [fyke net style]- Chart 8). The fish caught in the screw trap were on average larger than those caught in the small stream traps (Tables 4-8). The fish caught in the screw trap are a mix from all of the tributaries and the mainstem of the San Poil River, whereas the data in tables 4-7 are strictly the project streams. The time of trapping is fairly consistent between the trapping methods, although the screw trap was in until the beginning of August (stream traps were usually out by mid July due to low flows). In fact, most fish were trapped in both types near the end of June/beginning of July. At least three possibilities of the size disparity may be occurring. First, the larger juveniles (age 1 year) around 120-130mm may be leaving the tributaries in late fall or earlier in winter than it is possible to trap in the tributaries (ice and low flows), therefore increasing the large number in that size class at the screw trap. Second, the juveniles (YOY) may be staying in the mainstem of the San Poil River for a year before final migration to Lake Roosevelt (essentially doubling to quadrupling their size from 30-60 to $120-130 \mathrm{~mm}$ in one year). Third, the screw trap may not be able to adequately sample the smallest, YOY, fish (a problem for the fyke-net trap as well). For example, those fish less than the force of the water flow and larger (predatory) fish present in the holding tank may eliminate $25 \mathrm{~mm}$.

Table 8. Rainbow Trout Statistics from the San Poil River Screw Trap.

\begin{tabular}{|c|c|c|c|c|c|c|c|}
\hline \multicolumn{2}{|l|}{$1996 R B T$} & \multicolumn{2}{|l|}{$1997 R B T$} & \multicolumn{2}{|l|}{$1998 R B T$} & \multicolumn{2}{|l|}{$1999 R B T$} \\
\hline Mean & 120.2 & Mean & 124.1 & Mean & 137.4 & Mean & 133.2 \\
\hline Standard Error & 2.3 & Standard Error & 1.6 & Standard Error & 3.5 & Standard Error & 3.3 \\
\hline Median & 120 & Median & 123.5 & Median & 128.5 & Median & 129 \\
\hline Mode & 110 & Mode & 110 & Mode & 178 & Mode & 105 \\
\hline Standard Deviation & 32.7 & Standard Deviation & 32.3 & Standard Deviation & 51.0 & Standard Deviation & 54.9 \\
\hline Sample Variance & 1070.3 & Sample Variance & 1044.0 & Sample Variance & 2600.8 & Sample Variance & 3011.6 \\
\hline Kurtosis & 1.6 & Kurtosis & 1.6 & Kurtosis & 13.2 & Kurtosis & 43.7 \\
\hline Skewness & -0.6 & Skewness & 0.2 & Skewness & 2.3 & Skewness & 4.2 \\
\hline Range & 220 & Range & 235 & Range & 458 & Range & 689 \\
\hline Minimum & 10 & Minimum & 14 & Minimum & 46 & Minimum & 19 \\
\hline Maximum & 230 & Maximum & 249 & Maximum & 504 & Maximum & 708 \\
\hline Sum & 25359 & Sum & 49149 & Sum & 29138 & Sum & 35829 \\
\hline Count & 211 & Count & 396 & Count & 212 & Count & 269 \\
\hline Conf. Level(95.0\%) & 4.4 & Conf. Level(95.0\%) & 3.2 & Conf. Level(95.0\%) & 6.9 & Conf. Level(95.0\%) & 6.6 \\
\hline
\end{tabular}

Table 9. Rainbow Trout by Month and Year Caught in the San Poil River Screw Trap, CPUE and Trapping Days

\begin{tabular}{|r|r|r|r|r|r|r|}
\hline Year & April & May & June & July & Aug & TOTAL \\
\hline $\mathbf{1 9 9 6}$ & 17 & 11 & 43 & 141 & 0 & $\mathbf{2 1 2}$ \\
\hline $\mathbf{1 9 9 7}$ & 44 & 5 & 131 & 315 & 16 & $\mathbf{5 1 1}$ \\
\hline $\mathbf{1 9 9 8}$ & 36 & 85 & 12 & 92 & 3 & $\mathbf{2 2 8}$ \\
\hline $\mathbf{1 9 9 9}$ & 0 & 0 & 213 & 51 & 0 & $\mathbf{2 6 4}$ \\
\hline TOTAL & $\mathbf{9 7}$ & $\mathbf{1 0 1}$ & $\mathbf{3 9 9}$ & $\mathbf{5 9 9}$ & $\mathbf{1 9}$ & $\mathbf{1 , 2 1 5}$ \\
\hline
\end{tabular}

Catch Per Unit Effort (Day). Trapping Days

\begin{tabular}{|r|r|r|r|r|r|r|r|r|r|r|r|r|}
\hline Year & April & May & June & July & Aug & TOTAL & April & May & June & July & Aug & TOTAL \\
\hline $\mathbf{1 9 9 6}$ & 1.3 & 0.7 & 2.5 & 7.4 & NS & 3.3 & 13 & 15 & 17 & 19 & 0 & 64 \\
\hline $\mathbf{1 9 9 7}$ & 4.9 & 5.0 & 8.2 & 10.2 & 2.0 & 7.9 & 9 & 1 & 16 & 31 & 8 & 65 \\
\hline $\mathbf{1 9 9 8}$ & 3.6 & 7.7 & 6.0 & 6.6 & 1.0 & 5.7 & 10 & 11 & 2 & 14 & 3 & 40 \\
\hline $\mathbf{1 9 9 9}$ & NS & NS & 17.8 & 3.9 & 0.0 & 9.4 & 0 & 0 & 12 & 13 & 3 & 28 \\
\hline TOTAL & & & & & & & 32 & 27 & 47 & 77 & 14 & \\
\hline
\end{tabular}



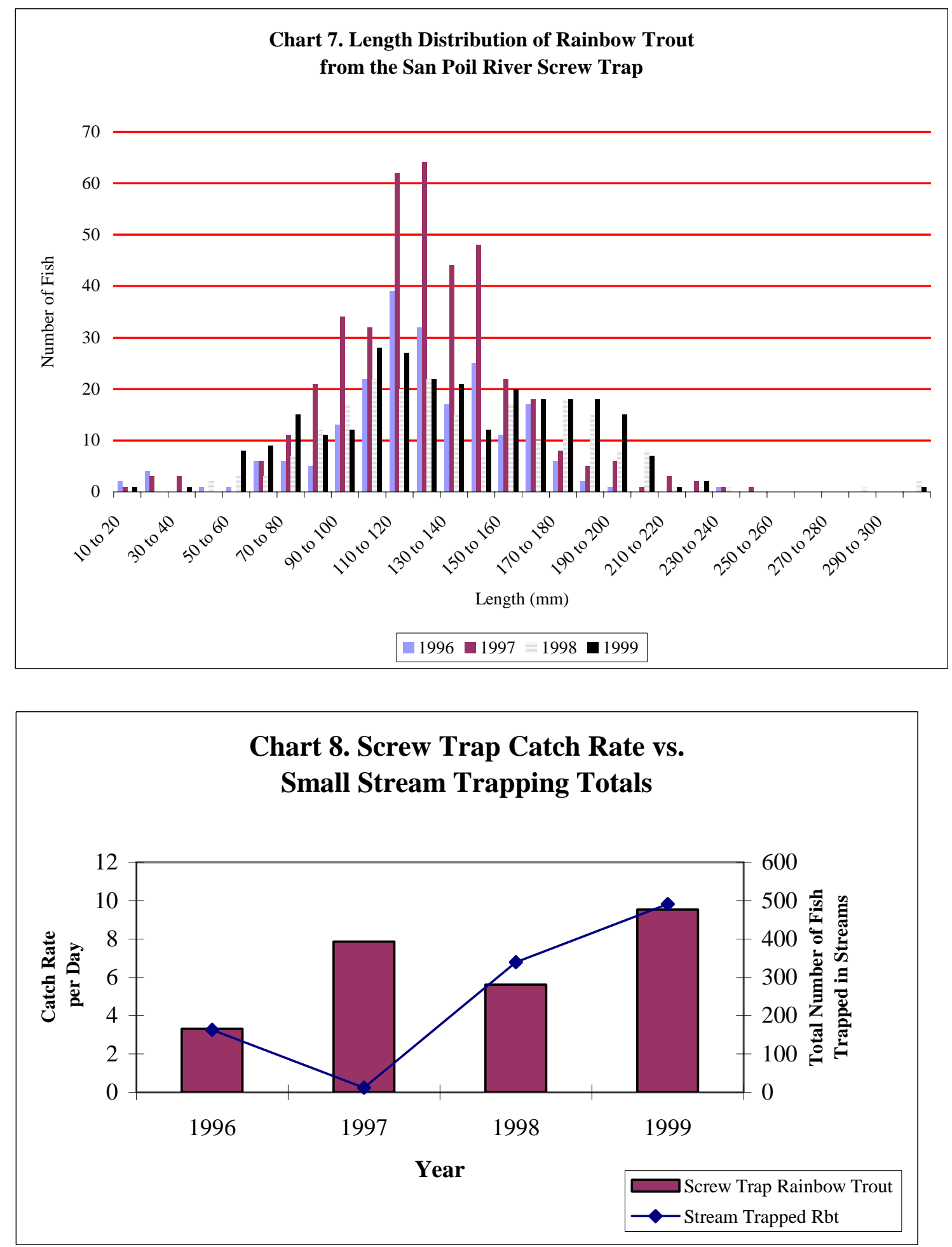


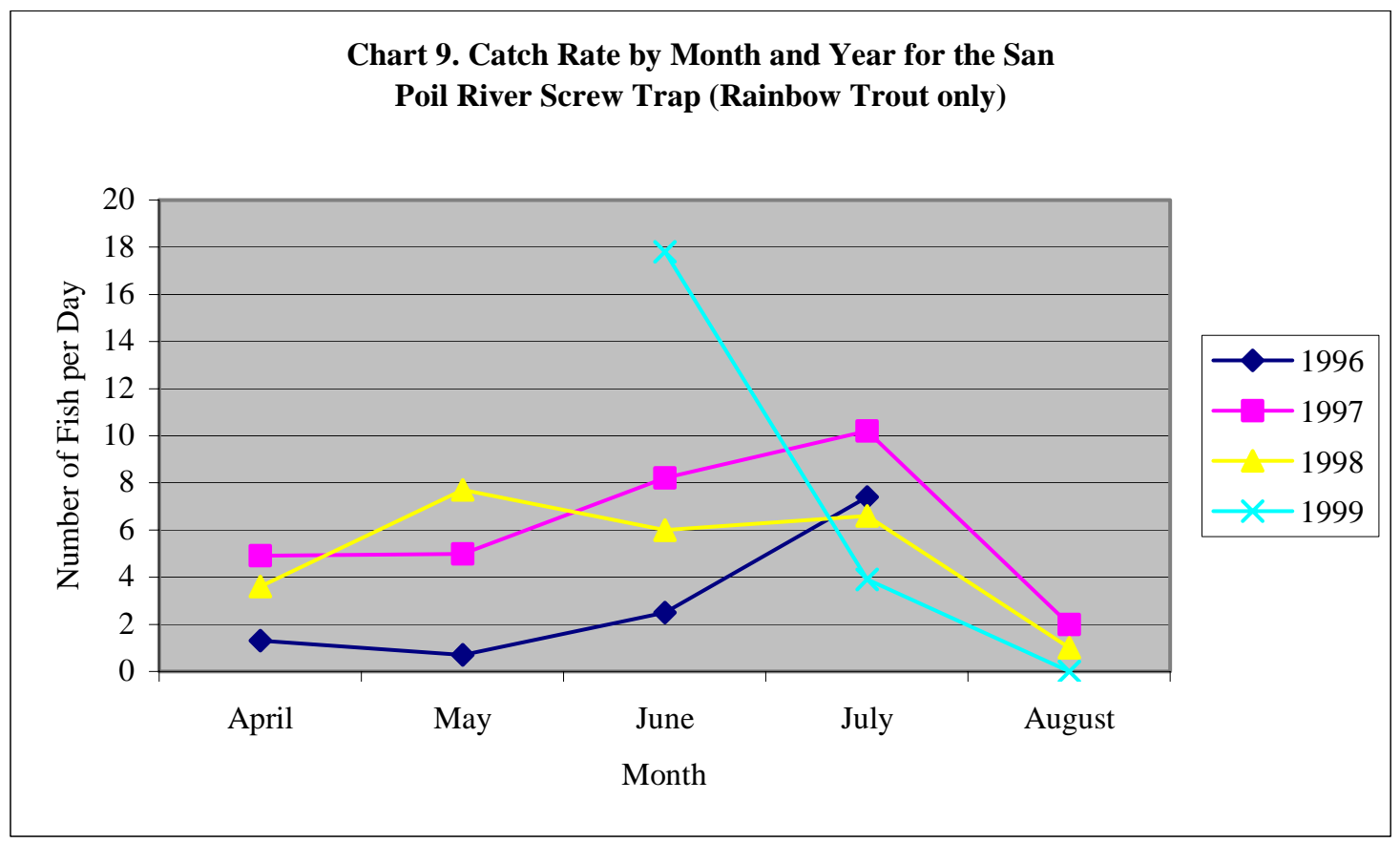

The average size of rainbow trout in 1998 and 1999 caught in the screw trap increased from 1996 and 1997. The reason for this is unknown. Most fish caught in all years was during June and July and therefore the size increase does not appear to have a time (month) relationship change from year to year. There is no strong, or distinct, age class distribution with the majority of the fish in 1996 or 1997, but there is a small break that may be an age class change in 1998 and 1999. If it is assumed that there are two age classes the past two years, a major age structure shift in the population may have occurred. It is also possible that there is just a highly variable size distribution and contribution from the various tributaries. The average size fish in the fyke net stream traps has done just the opposite: the average size has declined to under $50 \mathrm{~mm}$. This change may be reflected from the increase of the number of YOY fish that have been trapped in the past two years in the tributaries; many of these fish were trapped at 15 to $25 \mathrm{~mm}$. See also the population estimates and characterization in one of the following sections.

Other species caught and percentages are presented in Table 10. Sucker species dominate the percent composition (38\%). Scuker species plus rainbow trout, northern pikeminnow and redside shiners make up over 90 percent of the catch.

Table 10. Species Composition of the Species Captured in the San Poil Screw Trap

\begin{tabular}{|c|c|c|c|c|c|c|c|c|c|c|c|c|c|c|c|c|c|}
\hline \multirow[b]{2}{*}{ Yoar } & \multicolumn{5}{|c|}{$\begin{array}{l}\mathrm{SM}=\text { Smallmouth bass } \\
\mathrm{L}=\text { largemouth bass }\end{array}$} & \multicolumn{3}{|c|}{$\begin{array}{l}\mathrm{SR}=\text { shiner } \\
\mathrm{N}=\text { pikeminnow } \\
\mathrm{U}=\text { =unknown }\end{array}$} & \multicolumn{2}{|c|}{$\begin{array}{l}\mathrm{T}=\text { tench } \\
\mathrm{D}=\text { dace } \\
\mathrm{R}=\text { Rainbow }\end{array}$} & \multicolumn{4}{|c|}{$\begin{array}{l}\mathrm{SU}=\text { sucker } \\
\mathrm{B}=\text { burbot } \\
\mathrm{P}=\text { peamouth }\end{array}$} & \multicolumn{3}{|c|}{$\begin{array}{l}\mathrm{PE}=\text { perch } \\
\mathrm{C}=\text { chiselmouth } \\
\mathrm{SC}=\text { sculpin }\end{array}$} \\
\hline & \begin{tabular}{|l|l|}
$\mathrm{B}$ \\
\end{tabular} & $\mathrm{C}$ & $\mathrm{D}$ & $\mathrm{K}$ & $\mathrm{L}$ & $\mathrm{N}$ & \begin{tabular}{|l|l|}
$\mathrm{P}$ & \\
\end{tabular} & $\mathrm{PE}$ & $\mathrm{R}$ & SR & SC & SM & SU & $\mathrm{T}$ & $\mathrm{U}$ & EBT & TOTAL \\
\hline 1996 & 0 & 1 & 98 & 4 & 1 & 3 & 2 & 0 & 212 & \begin{tabular}{|l|}
157 \\
\end{tabular} & 29 & 1 & 123 & 11 & 40 & $\begin{array}{l}0 \\
\end{array}$ & 682 \\
\hline$\%$ & - & 0.1 & 14.4 & 0.6 & 0.1 & 0.4 & 0.3 & & 31.1 & 23.0 & 4.3 & 0.1 & 18.0 & 1.6 & 5.9 & & \\
\hline 1997 & 2 & 0 & 111 & 0 & 0 & 164 & 0 & 0 & 511 & 83 & 29 & 0 & 994 & 0 & 0 & 0 & 1,894 \\
\hline$\%$ & 0.1 & & 5.9 & & & 8.7 & & & 27.0 & 4.4 & 1.5 & & 52.5 & & & & \\
\hline 1998 & 0 & 0 & 12 & 0 & 0 & 4 & 1 & 1 & 225 & 58 & 40 & 0 & 128 & 0 & 0 & 0 & 469 \\
\hline$\%$ & - & & 2.6 & & & 0.9 & 0.2 & \begin{tabular}{l|}
0.2 \\
\end{tabular} & 48.0 & 12.4 & 8.5 & & 27.3 & & & - & \\
\hline 1999 & 0 & 0 & 5 & 1 & 0 & 379 & 0 & 0 & 267 & 188 & 17 & 1 & 386 & 0 & 2 & 1 & 1,247 \\
\hline$\%$ & & & 0.4 & 0.1 & & 30.4 & & & 21.4 & 15.1 & 1.4 & 0.1 & 31.0 & & 0.2 & 0.1 & \\
\hline ГOTAL & 2 & 1 & 226 & 5 & 1 & 550 & 3 & 1 & 1215 & 486 & 115 & 2 & |1631 & 11 & 42 & 1 & 4,292 \\
\hline$\%$ & 0.0 & 0.0 & 5.3 & 0.1 & 0.0 & 12.8 & 0.1 & 0.0 & 28.3 & 11.3 & \begin{tabular}{|l|}
2.7 \\
\end{tabular} & 0.0 & 38.0 & 0.3 & 1.0 & 0.0 & \\
\hline
\end{tabular}


Fish Population Estimates/Density Analysis

The pools and riffles were randomly selected for electroshocking in each stream on the project (Table 11). Approximately 10 percent of each habitat type, by area in the valley segment, were sampled. Juvenile rainbow trout population estimates per valley segment were calculated by averaging fish density per pool or riffle and multiplying that by the area in each category respectively (Table 13). Data summarized in valley segment (VS) three for Blue and North Nanamkin Creeks should be viewed with caution. The survey area was small such that data is probably biased for most/all parameters analyzed for those segments. Sculpins (Cottus sp.) were found in all five streams. An occasional eastern brook trout in some of the streams, but no populations of eastern brook trout appear to be established in any of the project streams. Some data from 1990/91 and 1997 is lost and is not available for complete analysis, but comparisons of fish density over time can be done nevertheless. Density was selected for trend analysis due to changing stream channel meanders from flooding events, varying water flow regimes, varying sample times, and some streams had no clearly identified start and end points established for the segments. These four factors prevent the use of the total number of fish per segment as an appropriate trend analysis tool. A t-Test for unequal variances (Two-Sample Assuming Unequal Variances) showed that there have been significant increases in densities of fish since 1990/91, although some streams declined from 1998 to 1999 (Table 12). Only streams with matching years of data were used for the t-test.

Table 11. Number of samples (habitat units) per reach per stream and time sampled.

\begin{tabular}{|c|c|c|c|c|c|c|c|c|c|}
\hline Stream & Reach & 1990 No. & Date ES & 1997 No. & Date ES & 1998 No. & Date ES & 1999 No. & Date ES \\
\hline \multirow[t]{3}{*}{ Blue } & 1 & 15 & 30-Jul & & ND & 19 & 19-Nov & 18 & 14-Sep \\
\hline & 2 & 8 & 22-Aug & & ND & 11 & 20-Nov & 26 & 15-Sep \\
\hline & 3 & $1 *$ & ND & & ND & & ND & 4 & 16-Sep \\
\hline \multirow[t]{2}{*}{ Iron } & 1 & 3 & 24-Jun & & ND & 1 & 22-Sep & 7 & 3-Aug \\
\hline & 2 & $3^{* *}$ & 24-Jun & & ND & 16 & 28-Sep & 14 & 4-Aug \\
\hline \multirow[t]{2}{*}{ Louie } & 1 & & ND & & ND & 5 & 29-Sep & 5 & 26-Aug \\
\hline & 2 & & ND & & ND & 12 & 30-Sep & 12 & 20-Sep \\
\hline \multirow[t]{3}{*}{ NN } & 1 & 1 & 26-Nov & 6 & 4-Dec & 4 & 30-Jul & 8 & 26-Jun \\
\hline & 2 & 9 & 26-Nov & 15 & 2-Dec & 18 & 17-Sep & 16 & 31-Oct \\
\hline & 3 & 4* & $26-\mathrm{Nov}$ & 17 & 18-Nov & 2 & 17-Sep & 6 & 2-Nov \\
\hline \multirow[t]{3}{*}{ SN } & 1 & & ND & 4 & 13-Nov & $18^{* * * *}$ & 29-Jul & 8 & 26-Jun \\
\hline & 2 & & ND & & ND & 17 & 2-Nov & 22 & 5-Nov \\
\hline & 3 & 11 & 26-Sep & & $\mathrm{ND}$ & 18 & 6-Nov & 21 & 10-Nov \\
\hline
\end{tabular}

*NO FISH IN REACH 3

**NO FISH IN LAST TWO UNITS

***THE LAST 8 UNITS WERE SHOCKED ON OCTOBER $14 T H$

Table 12. t-Test: Two-Sample Assuming Unequal Variances- Comparing Mean Fish Density Change Over Time.

\begin{tabular}{|l|r|r|r|r|r|r|r|r|r|r|}
\hline & $1990 / 91$ to & 1997 & $1990 / 91$ to & 1998 & $1990 / 91$ to & 1999 & 1997 to & 1998 & 1998 to & 1999 \\
\hline Mean & 0.59 & 1.01 & 0.45 & 1.75 & 0.41 & 1.86 & 1.01 & 2.86 & 1.75 & 1.99 \\
\hline Variance & 0.81 & 0.10 & 0.29 & 2.33 & 0.28 & 2.79 & 0.10 & 4.08 & 2.33 & 2.83 \\
\hline Observations & 4 & 4 & 12 & 12 & 13 & 13 & 4 & 4 & 12 & 12 \\
\hline Hypothesized Mean Difference & 0 & & 0 & & 0 & & 0 & & 0 & \\
\hline $\mathrm{df}$ & 4 & & 14 & & 14 & & 3 & & 22 & \\
\hline $\mathrm{t}$ Stat & -0.89 & & -2.79 & & -2.99 & & -1.81 & & -0.36 & \\
\hline $\mathrm{P}(\mathrm{T}<=\mathrm{t})$ one-tail & 0.21 & & 0.01 & & 0.00 & & 0.08 & & 0.36 & \\
\hline $\mathrm{t}$ Critical one-tail & 2.13 & & 1.76 & & 1.76 & & 2.35 & & 1.72 & \\
\hline $\mathrm{P}(\mathrm{T}<=\mathrm{t})$ two-tail & 0.42 & & 0.01 & & 0.01 & & 0.17 & & 0.72 & \\
\hline $\mathrm{t}$ Critical two-tail & 2.78 & & 2.14 & & 2.14 & & 3.18 & & 2.07 & \\
\hline
\end{tabular}


Table 13. Area, Fish Density and Population Estimates 1990-1999.

\begin{tabular}{|c|c|c|c|c|c|c|c|c|}
\hline & & Pool & Riffle & Pool Area & & Riffle Area & & \\
\hline Stream/segment/year & YEAR & Density & Density & Sampled & Pool Area & Sampled & Riffle Area & Total Fish \\
\hline Blue 11991 & 1991 & 0.7 & 0.4 & & 353.9 & & 3081.7 & 1480 \\
\hline Blue 21991 & 1991 & 0.8 & 0.1 & & 985.6 & & 5155.1 & 1304 \\
\hline Blue 31991 & 1991 & 0.0 & 0.0 & & 9984.2 & & 2190.1 & 0 \\
\hline Iron 11991 & 1991 & 0.04 & 0.05 & & 75.4 & & 718.8 & 39 \\
\hline Iron 21991 & 1991 & 0.1 & 0.0 & & 208 & & 3060.2 & 21 \\
\hline Louie 11990 & 1991 & 1.7 & 0.1 & & 733 & & 2029.5 & 1449 \\
\hline Louie 21990 & 1991 & 0.5 & 0.6 & & 243.1 & & 926.2 & 677 \\
\hline North Nanamkin 11991 & 1991 & 0.001 & 0.0 & & 0 & & 41692 & 0 \\
\hline North Nanamkin 21991 & 1991 & 0.5 & 0.4 & & 6291.7 & & 30809.5 & 15470 \\
\hline North Nanamkin 31991 & 1991 & 0.0 & 0.0 & & 0 & & 0 & 0 \\
\hline South Nanamkin 11990 & 1991 & 3.6 & 0.2 & & 209.6 & & 744.8 & 904 \\
\hline South Nanamkin 21990 & 1991 & 0.2 & 0.1 & & 7077.1 & & 1184.1 & 1534 \\
\hline South Nanamkin 31990 & 1991 & 0.2 & 0.4 & & 6393.7 & & 1415.7 & 1845 \\
\hline North Nanamkin 11997 & 1997 & 2.4 & 0.3 & 12.8 & 120.4 & 357.0 & 170.2 & 340 \\
\hline North Nanamkin 21997 & 1997 & 1.4 & 0.7 & 216.9 & 2508.4 & 249.9 & 7524.3 & 8779 \\
\hline North Nanamkin 31997 & 1997 & 1.5 & 0.6 & 177.5 & 63.9 & 399.4 & 147.2 & 184 \\
\hline \begin{tabular}{|lll} 
South Nanamkin 1997 & 199
\end{tabular} & 1997 & 0.6 & 0.6 & 39.2 & 160.7 & 69.2 & 617.5 & 467 \\
\hline Blue 11998 & 1998 & 0.7 & 0.1 & 272.1 & 2521.1 & 342.2 & 4495.4 & 2214 \\
\hline Blue 21998 & 1998 & 0.9 & 0.4 & 54.5 & 1398.6 & 174.7 & 5124.7 & 3309 \\
\hline Iron 11998 & 1998 & 0.0 & 0.3 & 0.0 & 45.3 & 57.8 & 575.6 & 173 \\
\hline Iron 21998 & 1998 & 2.1 & 1.2 & 79.6 & 753.7 & 218.7 & 2151.5 & 4165 \\
\hline Louie 11998 & 1998 & 2.1 & 1.0 & 25.0 & 142.7 & 72.0 & 584.9 & 885 \\
\hline Louie 21998 & 1998 & 4.8 & 1.3 & 46.6 & 689.3 & 354.1 & 3810.7 & 8263 \\
\hline North Nanamkin 11998 & 1998 & 0.8 & 0.7 & 58.0 & 318.7 & 228.8 & 1424.1 & 1252 \\
\hline North Nanamkin 21998 & 1998 & 3.9 & 0.8 & 186.9 & 1601.9 & 792.9 & 6034.1 & 11075 \\
\hline North Nanamkin 31998 & 1998 & 9.3 & 1.9 & 4.1 & 41.6 & 26.5 & 284.5 & 927 \\
\hline South Nanamkin 11998 & 1998 & 4.3 & 1.2 & 111.5 & 471.6 & 89.7 & 1065.4 & 3306 \\
\hline South Nanamkin 21998 & 1998 & 1.5 & 1.2 & 230.3 & 1096.4 & 316.8 & 4356 & 6872 \\
\hline South Nanamkin 31998 & 1998 & 0.9 & 0.6 & 183.7 & 759.4 & 386.9 & 2781.7 & 2352 \\
\hline Blue 11999 & 1999 & 1.2 & 0.6 & 165.6 & 1576 & 392.1 & 3452.8 & 3963 \\
\hline Blue 21999 & 1999 & 0.5 & 0.3 & 159.6 & 1210.7 & 561.0 & 4978.2 & 2099 \\
\hline Blue 31999 & 1999 & 0.6 & 0.2 & 21.2 & 79.9 & 41.9 & 34.5 & 55 \\
\hline Iron 11999 & 1999 & 6.9 & 2.4 & 29.4 & 296.8 & 69.6 & 643 & 3591 \\
\hline Iron 21999 & 1999 & 4.3 & 3.0 & 42.9 & 242.3 & 221.9 & 1157.5 & 4514 \\
\hline Iron 31999 & 1999 & 6.7 & 1.7 & 27.2 & 179.1 & 156.5 & 1215.2 & 3266 \\
\hline Louie 11999 & 1999 & 3.2 & 2.8 & 28.5 & 177.4 & 102.9 & 578.2 & 2187 \\
\hline Louie 21999 & 1999 & 7.0 & 3.0 & 59.2 & 588.6 & 456.4 & 3415.1 & 14366 \\
\hline North Nanamkin 11999 & 1999 & 0.8 & 0.4 & 124.5 & 100.4 & 475.3 & 2990.4 & 1276 \\
\hline North Nanamkin 21999 & 1999 & 2.3 & 0.6 & 159.9 & 1788.7 & 451.5 & 4088.5 & 6567 \\
\hline North Nanamkin 31999 & 1999 & 1.7 & 0.3 & 46.8 & 160.2 & 231.1 & 395.9 & 391 \\
\hline South Nanamkin 11999 & 1999 & 1.7 & 0.7 & 120.4 & 490.3 & 240.2 & 2000.6 & 2234 \\
\hline South Nanamkin 21999 & 1999 & 1.4 & 0.7 & 211.5 & 958.2 & 665.5 & 4054.3 & 4179 \\
\hline South Nanamkin 31999 & 1999 & 0.8 & 0.5 & 176.5 & 726.1 & 464.3 & 2518.2 & 1840 \\
\hline
\end{tabular}

*1990/91 data in this analysis has had Scour Pool Cascade units changed to pool habitat type instead of riffle. 


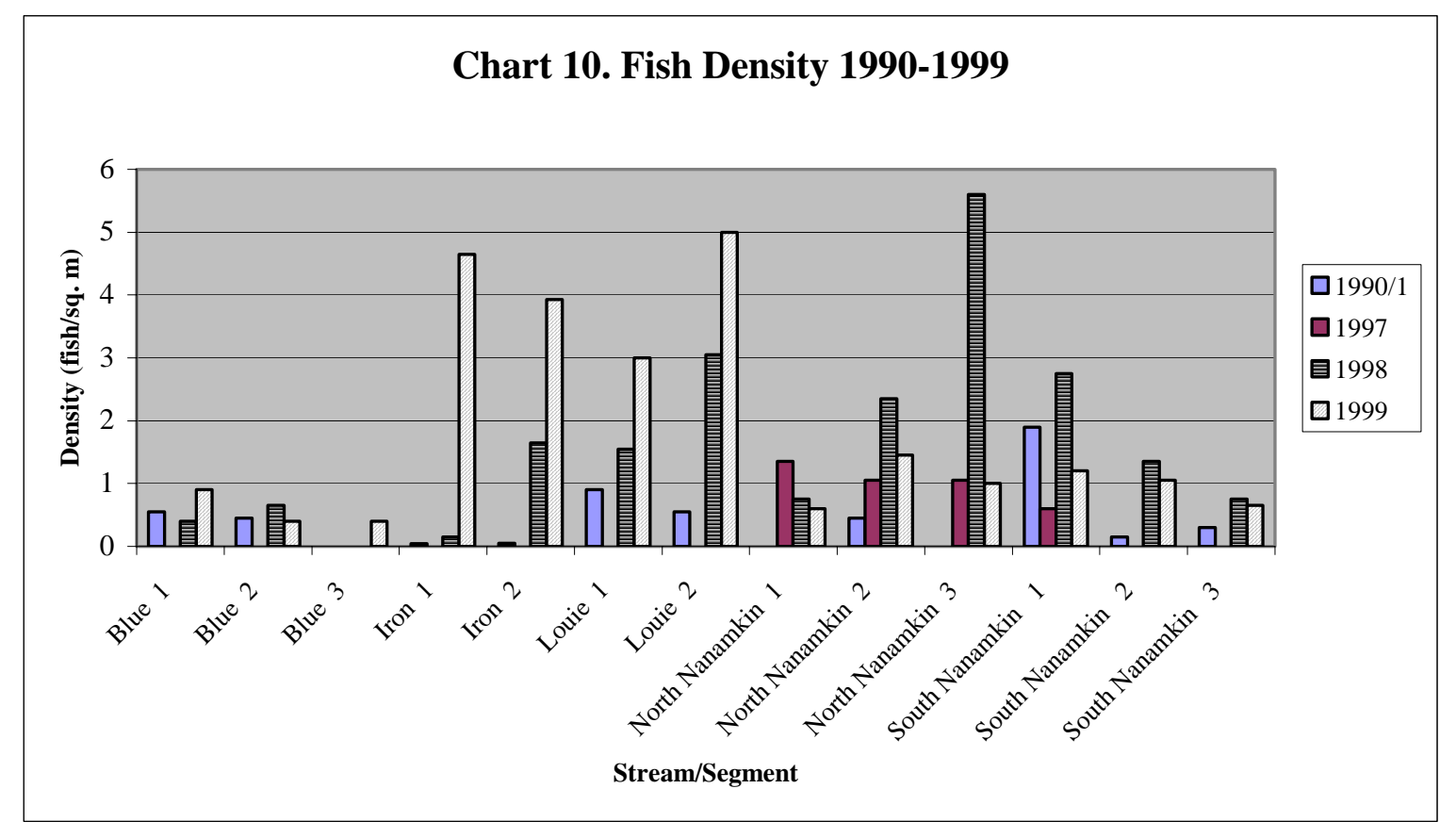

For example, in the 1990/91 and 1997 data sets, only North Nanamkin segments one, two and three and South Nanamkin segment one were used to evaluate the mean density changes $(n=4)$, versus 1990/91 and 1999 where $n=13$ (better data collection occurred in 1999). Using the analysis and data trends depicted in Chart 10, it appears that there has been a significant increase in the density of juvenile rainbow trout in all streams since 1990-91. Some individual reaches have been variable (segment 2- Blue Creek), but overall the streams have had an increase. Segment 3 in North Nanamkin and Blue Creeks had no fish present in 1990/91.

The fish captured during electroshocking had lengths taken to examine the population structure in each stream. Tables 14-17 depicts the data for every year and Charts 11-26 graphically show the length distribution. Table 18 is a full list of the descriptive statistics of the population in every segment and year.

Table 14. Lengths of Rainbow Trout Captured Electroshocking, 1990-91

\begin{tabular}{|l|r|r|r|r|c|}
\hline Size & & & & North & South \\
\hline Range & Blue & Iron & Louie & Nanamkin & Nanamkin \\
\hline$<30$ & 44 & 0 & 0 & 0 & 0 \\
\hline $\mathbf{3 0 - 4 0}$ & 1 & 0 & 0 & 0 & 0 \\
\hline $\mathbf{4 0 - 5 0}$ & 19 & 0 & 0 & 0 & 0 \\
\hline $\mathbf{5 0 - 6 0}$ & 29 & 0 & 0 & 1 & 0 \\
\hline $\mathbf{6 0 - 7 0}$ & 18 & 0 & 0 & 7 & 0 \\
\hline $\mathbf{7 0 - 8 0}$ & 12 & 0 & 0 & 105 & 4 \\
\hline $\mathbf{8 0 - 9 0}$ & 12 & 3 & 0 & 130 & 8 \\
\hline $\mathbf{9 0 - 1 0 0}$ & 11 & 2 & 0 & 14 & 9 \\
\hline $\mathbf{1 0 0 - 1 1 0}$ & 17 & 2 & 0 & 4 & 13 \\
\hline $\mathbf{1 1 0 - 1 2 0}$ & 20 & 0 & 0 & 1 & 27 \\
\hline $\mathbf{1 2 0 - 1 3 0}$ & 10 & 1 & 0 & 4 & 21 \\
\hline $\mathbf{1 3 0 - 1 4 0}$ & 14 & 0 & 0 & 10 & 15 \\
\hline $\mathbf{1 4 0 - 1 5 0}$ & 12 & 4 & 0 & 2 & 10 \\
\hline $\mathbf{1 5 0 - 1 6 0}$ & 15 & 3 & 0 & 3 & 12 \\
\hline $\mathbf{1 6 0 - 1 7 0}$ & 8 & 3 & 0 & 3 & 12 \\
\hline $\mathbf{1 7 0 - 1 8 0}$ & 8 & 0 & 0 & 0 & 8 \\
\hline $\mathbf{1 8 0 - 1 9 0}$ & 4 & 0 & 0 & 0 & 1 \\
\hline
\end{tabular}


Table 14. (continued)

\begin{tabular}{|l|r|r|r|c|c|}
\hline Size & & & & North & South \\
\hline Range & Blue & Iron & Louie & Nanamkin & Nanamkin \\
\hline $\mathbf{1 9 0 - 2 0 0}$ & 1 & 0 & 0 & 1 & 3 \\
\hline $\mathbf{2 0 0 - 2 1 0}$ & 1 & 0 & 0 & 0 & 2 \\
\hline $\mathbf{2 1 0 - 2 2 0}$ & 1 & 1 & 0 & 0 & 3 \\
\hline $\mathbf{2 2 0 - 2 3 0}$ & 1 & 0 & 0 & 0 & 0 \\
\hline $\mathbf{2 3 0 - 2 4 0}$ & 0 & 0 & 0 & 0 & 0 \\
\hline $\mathbf{2 4 0 - 2 5 0}$ & 0 & 0 & 0 & 0 & 0 \\
\hline$>\mathbf{2 5 0}$ & 0 & 0 & 0 & 0 & 0 \\
\hline
\end{tabular}

Table 15. Lengths of Rainbow Trout Captured Electroshocking, 1997

\begin{tabular}{|c|c|c|c|c|c|}
\hline Size & & & & North & South \\
\hline Range & Blue & Iron & Louie & Nanamkin & Nanamkin \\
\hline$<30$ & 0 & 0 & 0 & 1 & 0 \\
\hline $30-40$ & 0 & 0 & 0 & 16 & 0 \\
\hline $40-50$ & 0 & 0 & 0 & 199 & 3 \\
\hline $50-60$ & 0 & 0 & 0 & 289 & 15 \\
\hline $60-70$ & 0 & 0 & 0 & 203 & 26 \\
\hline $70-80$ & 0 & 0 & 0 & 61 & 7 \\
\hline $80-90$ & 0 & 0 & 0 & 27 & 3 \\
\hline 90-100 & 0 & 0 & 0 & 46 & 0 \\
\hline $100-110$ & 0 & 0 & 0 & 36 & 1 \\
\hline $110-120$ & 0 & 0 & 0 & 26 & 1 \\
\hline $120-130$ & 0 & 0 & 0 & 19 & 1 \\
\hline $130-140$ & 0 & 0 & 0 & 8 & 1 \\
\hline $140-150$ & 0 & 0 & 0 & 10 & 0 \\
\hline $150-160$ & 0 & 0 & 0 & 5 & 0 \\
\hline $160-170$ & 0 & 0 & 0 & 1 & 0 \\
\hline $170-180$ & 0 & 0 & 0 & 2 & 0 \\
\hline $180-190$ & 0 & 0 & 0 & 1 & 0 \\
\hline $190-200$ & 0 & 0 & 0 & 1 & 0 \\
\hline $200-210$ & 0 & 0 & 0 & 0 & 0 \\
\hline $210-220$ & 0 & 0 & 0 & 0 & 0 \\
\hline $220-230$ & 0 & 0 & 0 & 0 & 0 \\
\hline $230-240$ & 0 & 0 & 0 & 0 & 0 \\
\hline $240-250$ & 0 & 0 & 0 & 0 & 0 \\
\hline$>250$ & 0 & 0 & 0 & 0 & 0 \\
\hline
\end{tabular}

Table 16. Lengths of Rainbow Trout Captured Electroshocking, 1998

\begin{tabular}{|l|r|r|r|r|r|}
\hline Size & & & & \multicolumn{1}{l|}{ North } & South \\
\hline Range & Blue & Iron & Louie & Nanamkin & Nanamkin \\
\hline$<30$ & 0 & 0 & 0 & 0 & 0 \\
\hline $\mathbf{3 0 - 4 0}$ & 0 & 6 & 1 & 1 & 6 \\
\hline $\mathbf{4 0 - 5 0}$ & 0 & 28 & 45 & 70 & 56 \\
\hline $\mathbf{5 0 - 6 0}$ & 1 & 137 & 205 & 438 & 273 \\
\hline $\mathbf{6 0 - 7 0}$ & 20 & 107 & 165 & 559 & 510 \\
\hline $\mathbf{7 0 - 8 0}$ & 33 & 56 & 52 & 84 & 106 \\
\hline $\mathbf{8 0 - 9 0}$ & 28 & 15 & 24 & 20 & 52 \\
\hline $\mathbf{9 0 - 1 0 0}$ & 81 & 20 & 56 & 58 & 66 \\
\hline $\mathbf{1 0 0 - 1 1 0}$ & 90 & 12 & 28 & 103 & 53 \\
\hline $\mathbf{1 1 0 - 1 2 0}$ & 45 & 5 & 44 & 49 & 39 \\
\hline $\mathbf{1 2 0 - 1 3 0}$ & 44 & 2 & 20 & 27 & 44 \\
\hline
\end{tabular}


Table 16. (continued)

\begin{tabular}{|l|r|r|r|r|r|}
\hline Size & & & & \multicolumn{1}{l|}{ lorth } & \multicolumn{1}{l|}{ South } \\
\hline Range & Blue & Iron & \multicolumn{1}{l|}{ Louie } & Nanamkin & Nanamkin \\
\hline $\mathbf{1 3 0 - 1 4 0}$ & 26 & 5 & 7 & 0 & 42 \\
\hline $\mathbf{1 4 0 - 1 5 0}$ & 12 & 2 & 2 & 19 & 11 \\
\hline $\mathbf{1 5 0 - 1 6 0}$ & 28 & 0 & 2 & 23 & 5 \\
\hline $\mathbf{1 6 0 - 1 7 0}$ & 8 & 1 & 3 & 0 & 6 \\
\hline $\mathbf{1 7 0 - 1 8 0}$ & 5 & 0 & 0 & 21 & 1 \\
\hline $\mathbf{1 8 0 - 1 9 0}$ & 13 & 0 & 3 & 11 & 7 \\
\hline $\mathbf{1 9 0 - 2 0 0}$ & 4 & 0 & 1 & 0 & 1 \\
\hline $\mathbf{2 0 0 - 2 1 0}$ & 7 & 1 & 0 & 0 & 0 \\
\hline $\mathbf{2 1 0 - 2 2 0}$ & 0 & 0 & 0 & 0 & 0 \\
\hline $\mathbf{2 2 0 - 2 3 0}$ & 0 & 0 & 0 & 0 & 0 \\
\hline $\mathbf{2 3 0 - 2 4 0}$ & 0 & 0 & 0 & 0 & 0 \\
\hline $\mathbf{2 4 0 - 2 5 0}$ & 0 & 0 & 0 & 0 & 0 \\
\hline$>\mathbf{2 5 0}$ & 0 & 0 & 0 & 0 & 0 \\
\hline
\end{tabular}

Table 17. Lengths of Rainbow Trout Captured Electroshocking, 1999

\begin{tabular}{|c|c|c|c|c|c|}
\hline Size & & & & North & South \\
\hline Range & Blue & Iron & Louie & Nanamkin & Nanamkin \\
\hline$<30$ & 1 & 885 & 97 & 78 & 458 \\
\hline $30-40$ & 15 & 149 & 509 & 12 & 7 \\
\hline $40-50$ & 27 & 181 & 18 & 15 & 9 \\
\hline $50-60$ & 45 & 6 & 278 & 284 & 124 \\
\hline 60-70 & 115 & 28 & 60 & 37 & 186 \\
\hline 70-80 & 40 & 11 & 16 & 299 & 302 \\
\hline $80-90$ & 54 & 12 & 38 & 78 & 112 \\
\hline $90-100$ & 10 & 0 & 5 & 19 & 22 \\
\hline 100-110 & 54 & 0 & 10 & 12 & 66 \\
\hline $110-120$ & 38 & 8 & 14 & 21 & 61 \\
\hline 120-130 & 12 & 1 & 14 & 10 & 29 \\
\hline 130-140 & 22 & 5 & 5 & 12 & 19 \\
\hline 140-150 & 1 & 2 & 3 & 0 & 5 \\
\hline $150-160$ & 6 & 3 & 1 & 0 & 10 \\
\hline 160-170 & 13 & 1 & 1 & 0 & 3 \\
\hline 170-180 & 4 & 1 & 1 & 0 & 3 \\
\hline 180-190 & 3 & 1 & 3 & 0 & 6 \\
\hline 190-200 & 3 & 0 & 0 & 0 & 0 \\
\hline $200-210$ & 2 & 3 & 0 & 0 & 10 \\
\hline $210-220$ & 5 & 3 & 1 & 1 & 3 \\
\hline $220-230$ & 2 & 0 & 0 & 0 & 0 \\
\hline $230-240$ & 0 & 0 & 0 & 0 & 0 \\
\hline $240-250$ & 0 & 0 & 0 & 0 & 0 \\
\hline$>250$ & 0 & 0 & 0 & 0 & 0 \\
\hline
\end{tabular}



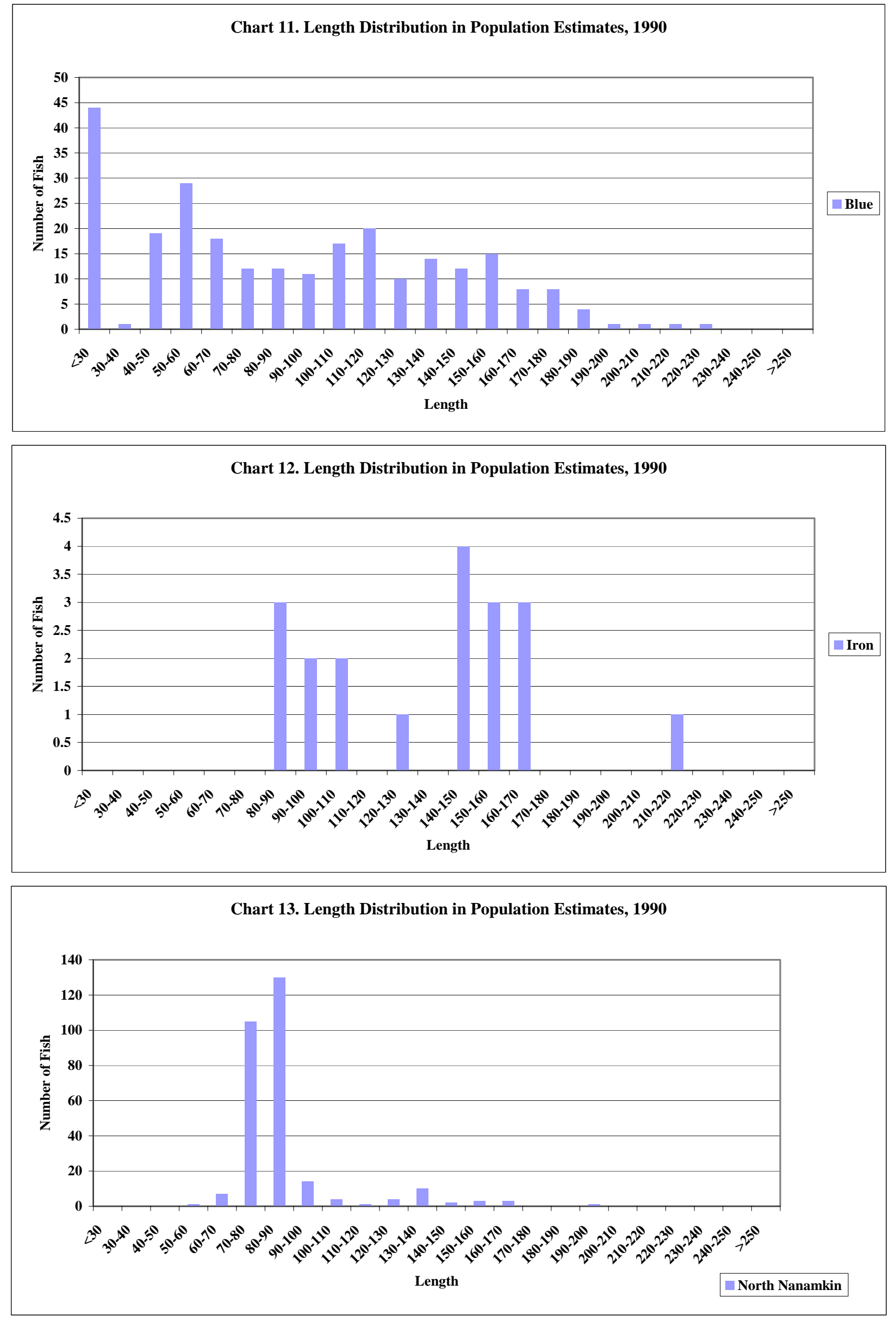

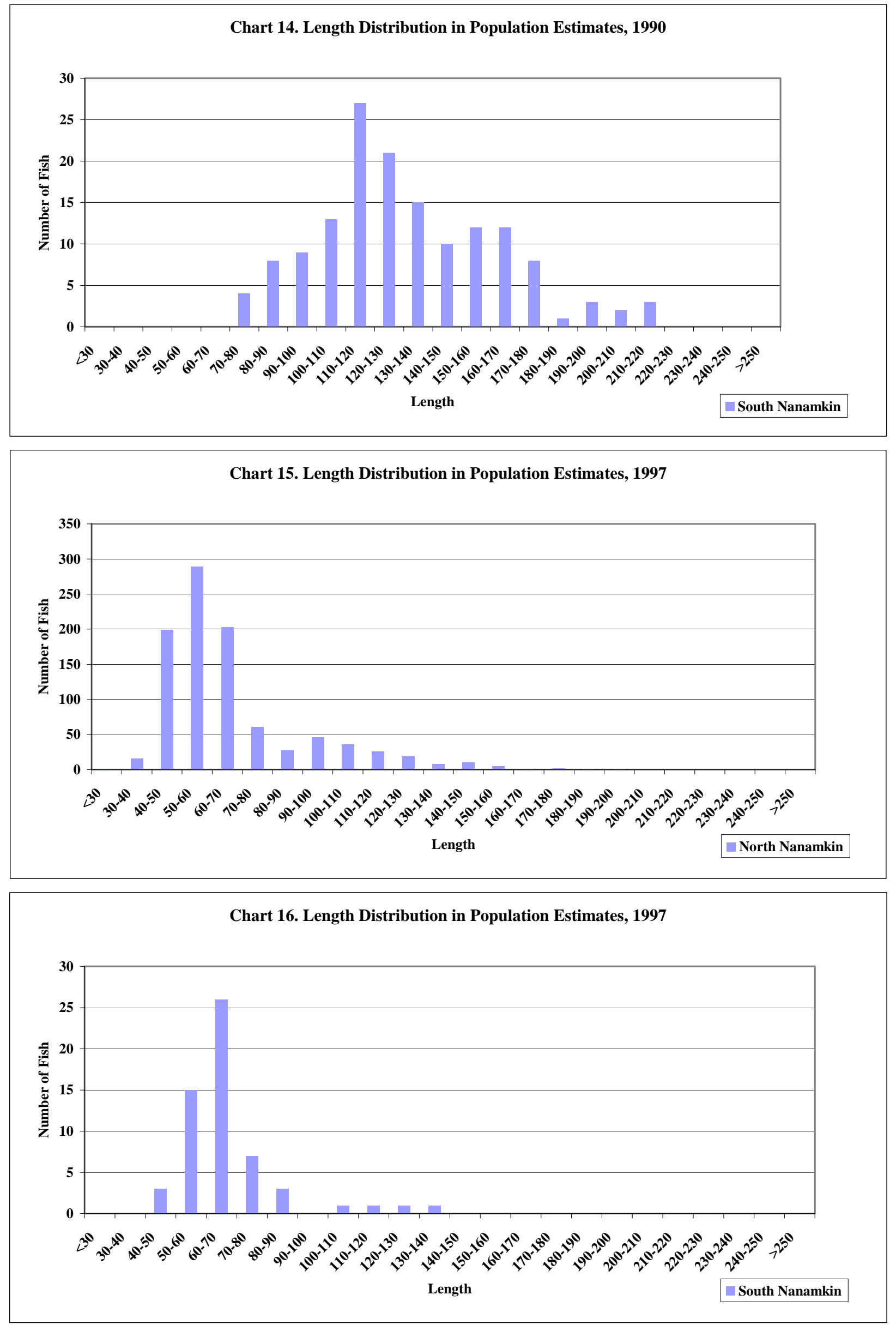

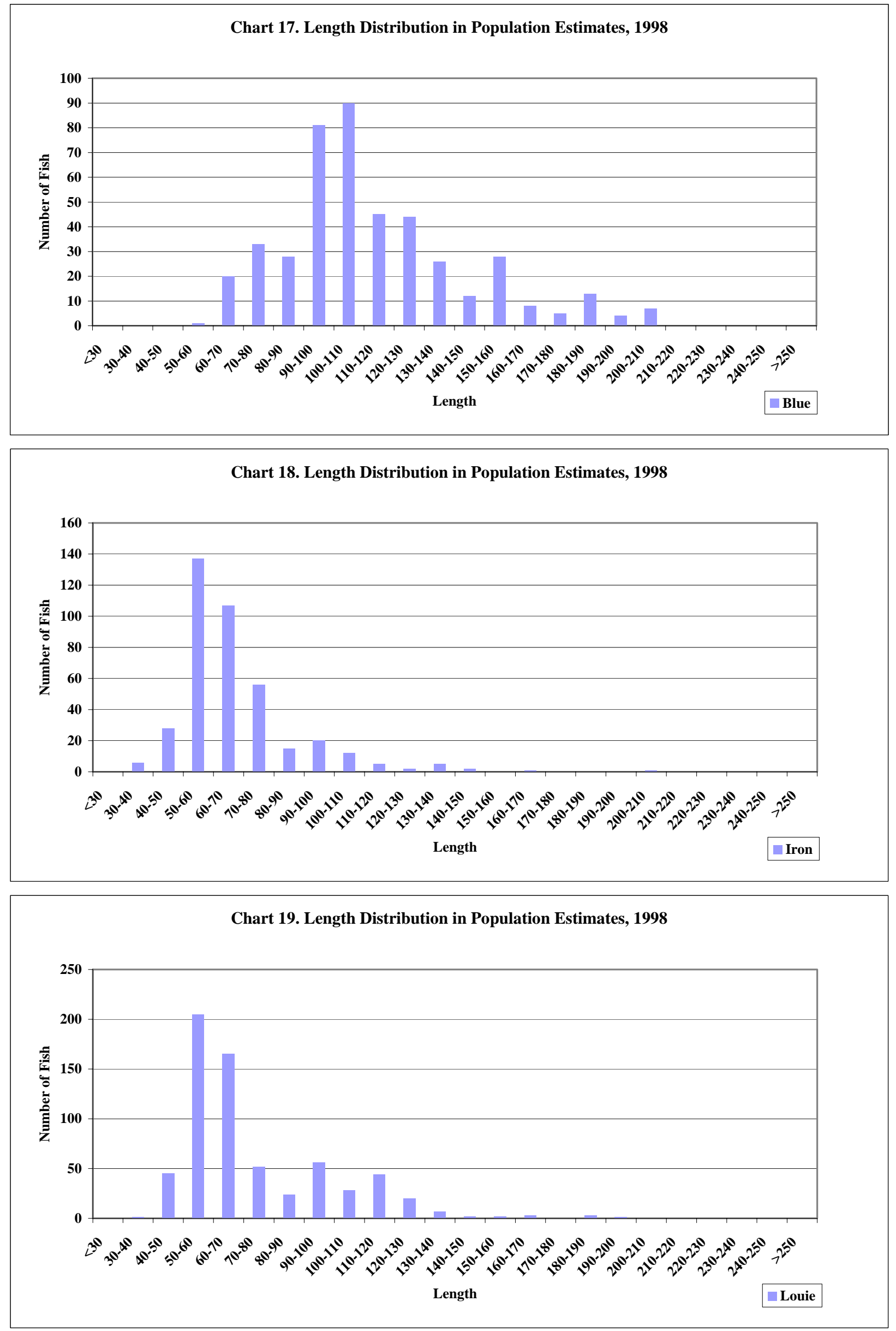

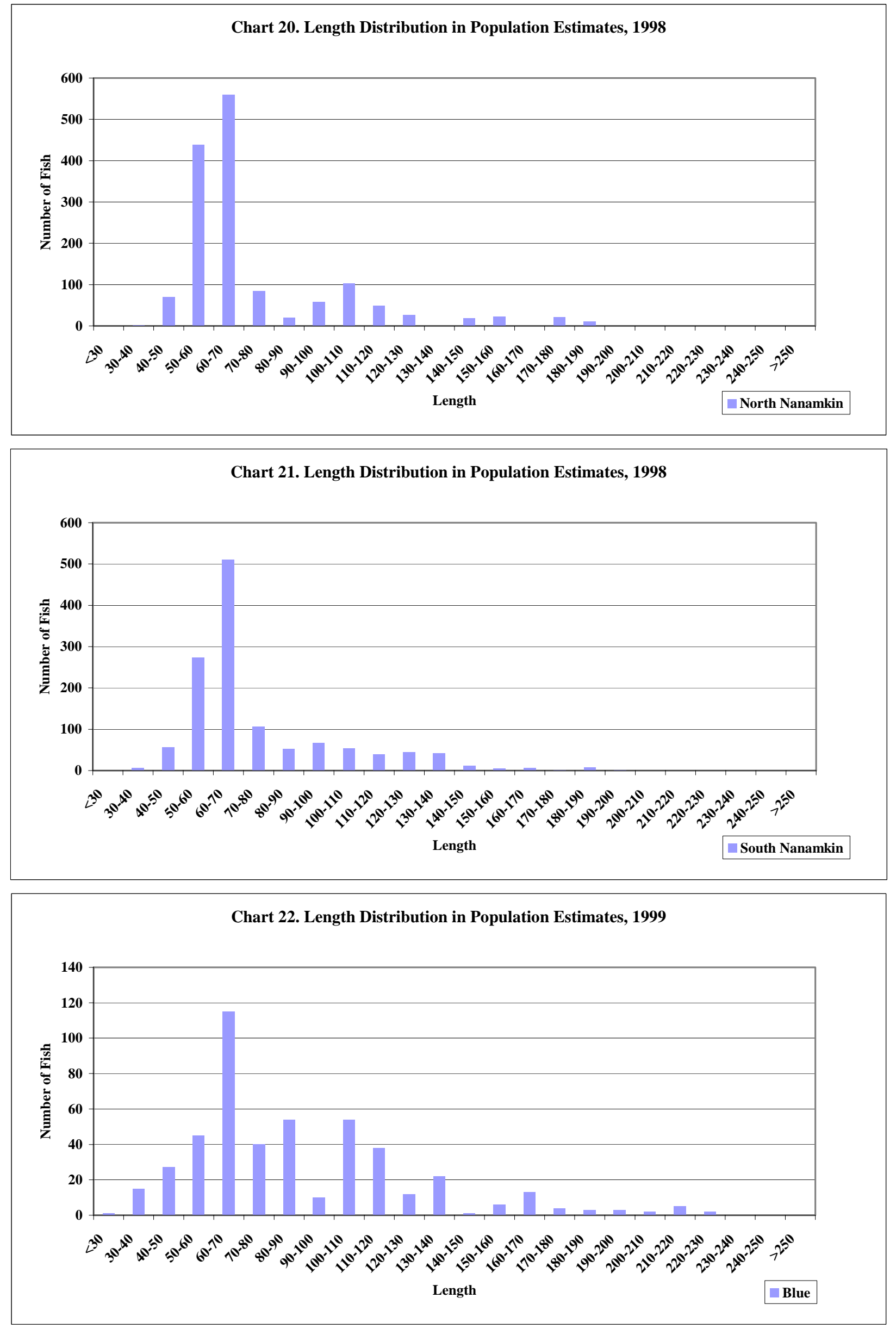

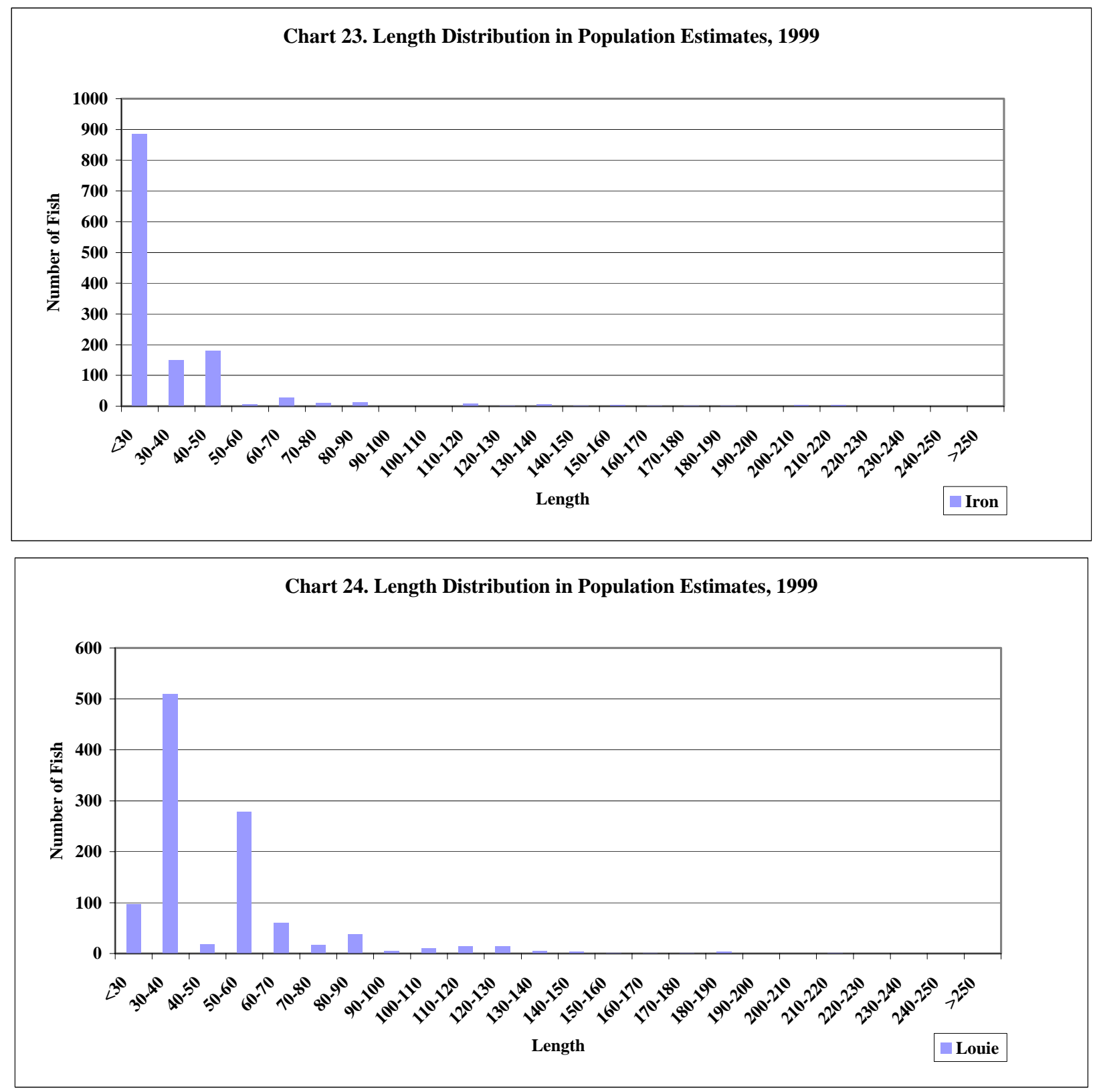

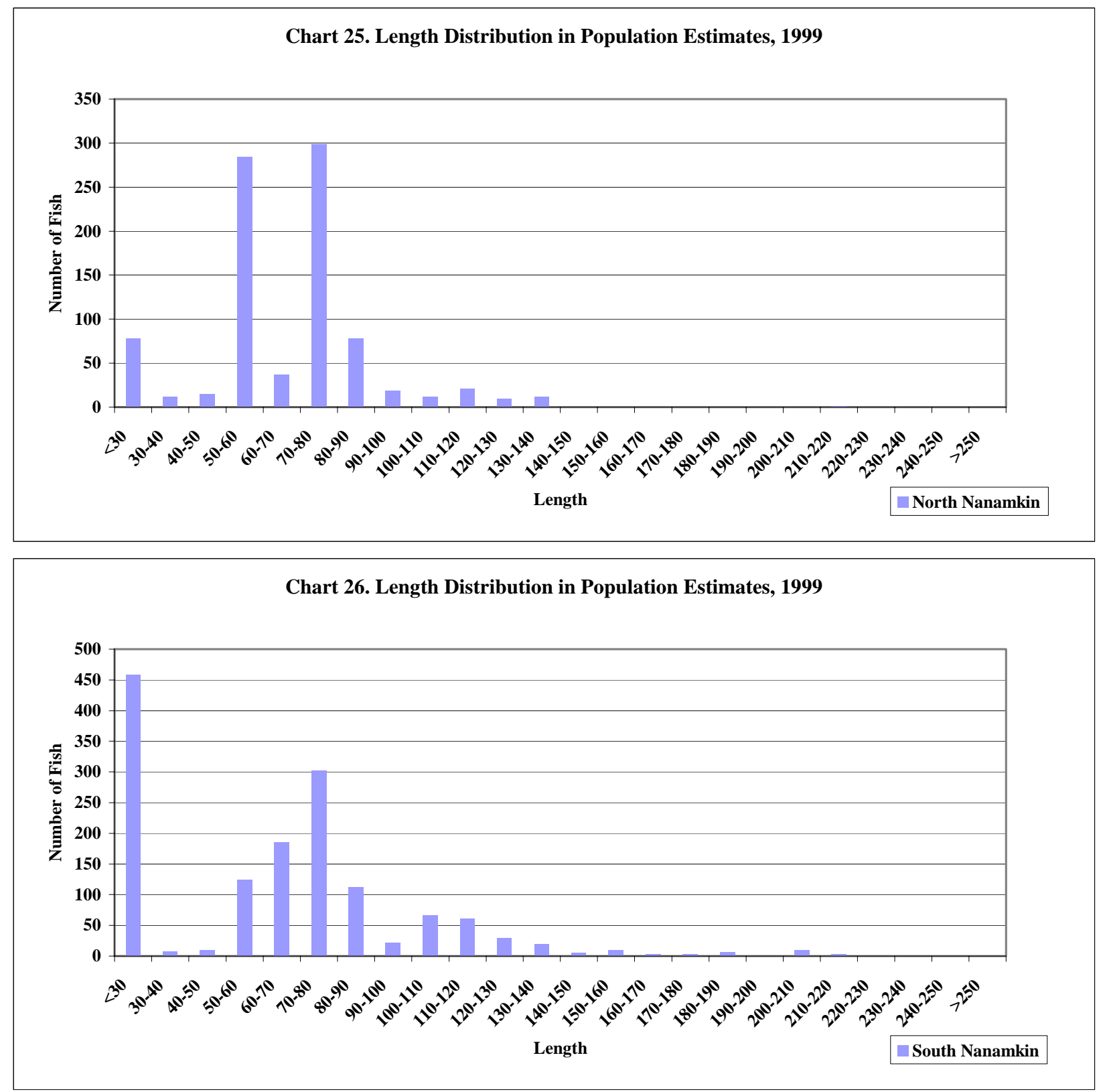
Table 18. Electroshocked Fish Population Statistics for Length.

\begin{tabular}{|l|r|r|r|r|r|r|r|r|r|r|r|}
\hline & & $1990 / 91$ & mean & median & & & 1997 & mean & median & & \\
\hline Stream & Segment & $\mathrm{N}$ & Lth & Lth & $95 \%$ CI & SD & N & Lth & Lth & $95 \%$ CI & SD \\
\hline Blue & 1 & 146 & 102 & 104 & 8 & 51 & 0 & & & & \\
\hline & 2 & 115 & 73 & 82 & 9 & 47 & 0 & & & & \\
\hline Iron & 3 & $\mathrm{NF}$ & & & & & 0 & & & & \\
\hline & 1 & 12 & 97 & 82 & 29 & 46 & 0 & & & & \\
\hline Louie & 2 & 10 & 143 & 142 & 5 & 6 & 0 & & & & \\
\hline & 1 & 0 & & & & & 0 & & & & \\
\hline NN & 2 & 0 & & & & & 0 & & & & \\
\hline & 1 & 3 & 130 & 122 & 34 & 14 & 317 & 62 & 55 & 3 & 26 \\
\hline & 3 & 301 & 76 & 70 & 2 & 20 & 421 & 66 & 58 & 2 & 26 \\
\hline SN & 1 & 0 & & & & & 248 & 70 & 65 & 3 & 21 \\
\hline & 2 & 0 & & & & & 0 & & & & \\
\hline & 3 & 162 & 122 & 115 & 5 & 34 & 0 & & & & \\
\hline & & 1998 & mean & median & & & 1999 & mean & median & & \\
\hline Stream & Segment & $\mathrm{N}$ & Lth & Lth & $95 \% \mathrm{CI}$ & SD & N & Lth & Lth & $95 \%$ CI & SD \\
\hline Blue & 1 & 310 & 116 & 105 & 4 & 36 & 281 & 77 & 64 & 5 & 39 \\
\hline & 2 & 143 & 105 & 100 & 4 & 24 & 206 & 89 & 80 & 5 & 35 \\
\hline & 3 & 0 & & & & & 20 & 99 & 100 & 17 & 36 \\
\hline Iron & 1 & 16 & 58 & 51 & 7 & 12 & 337 & 25 & 21 & 1 & 10 \\
\hline & 2 & 397 & 67 & 61 & 2 & 20 & 974 & 34 & 25 & 2 & 24 \\
\hline Louie & 1 & 131 & 74 & 61 & 4 & 23 & 350 & 43 & 40 & 2 & 23 \\
\hline & 2 & 527 & 56 & 64 & 2 & 26 & 862 & 45 & 35 & 2 & 24 \\
\hline NN & 1 & 265 & 56 & 55 & 1 & 8 & 266 & 53 & 54 & 3 & 25 \\
\hline & 2 & 1261 & 75 & 65 & 2 & 28 & 521 & 65 & 70 & 2 & 18 \\
\hline & 3 & 86 & 75 & 59 & 6 & 28 & 150 & 72 & 70 & 4 & 24 \\
\hline SN & 1 & 639 & 66 & 61 & 2 & 21 & 507 & 25 & 20 & 1 & 14 \\
\hline & 2 & 299 & 77 & 65 & 3 & 27 & 619 & 78 & 70 & 2 & 25 \\
\hline & 3 & 347 & 86 & 70 & 3 & 31 & 322 & 81 & 70 & 4 & 37 \\
\hline
\end{tabular}

*NF= no fish present

The segment data for the length distributions were lumped into one data set per stream such that the whole stream population is used to examine age structure. One problem that occurs when doing this is that the data were not taken at the same time in every segment. The samples taken in segment one in North and South Nanamkin Creeks were dominated by YOY; the $30 \mathrm{~mm}$ size class. These fish are the $50-70 \mathrm{~mm}$ size fish sampled later in the season in the upper segments. Ignoring the obvious break of this size class $(30 \mathrm{~mm})$ and considering them as the $50-70 \mathrm{~mm}$ size class electroshocked later in the season, the rest of the data was used to describe the age structure. Blue Creek appears to have at least three-year classes $(0,1$, and 2) with a few larger fish. The relative number of fish in the two older year classes seems to have decreased in 1998 and 1999 compared to 1990. A similar occurrence, although more pronounced, occurs in Iron Creek where there were two distinct size classes $(0,1)$ in 1990, and only one appears in 1998 and 1999. The variability of the size class in 1998 and 1999 is probably due to fish spawning over a two to three month period and variable emergence of the fry. Louie Creek data was lost for 1990. The 1998 and 1999 data show that Louie Creek had a single year class present (0), a second age class may exist, but is weak or sampling error may have occurred, and very few fish in larger size/age classes. The fish population in North Nanamkin Creek appears to have at least two distinct age classes $(0,1)$ for all years and possibly a 
third may have occurred in the 1998 group. South Nanamkin Creek may have had three year classes in 1990 and $1999(0,1$, and 2), although there is not a distinct break in the data to confirm the oldest age class. In 1997 and 1998 there appears to be only two age groups. The data from South Nanamkin Creek 1997 is limited because it only has data from segment one, which normally goes dry during the late summer and early fall. Mean length of juvenile rainbow trout has decreased in recent years in Iron, Louie, North and South Nanamkin Creeks, and increased in Blue Creek, but may be attributed to changes in the timing of the surveys and/or increased density has resulted in smaller fish through competition.

Their does not seem to be a relationship of Lake Roosevelt draw downs with juvenile fish capture (r square= 0.07), which was surprising in that effort declines with high water years (number of days and efficiency drops with high flow). Adult return and juveniles captured were fairly well related (r square= 0.69), and is probably due to the similar effort in trapping: both are trapped concurrently in the same area. The reason for the disparity of the juveniles compared to Lake Roosevelt drawdowns is not clear.

\begin{tabular}{lr}
\multicolumn{2}{l}{$\begin{array}{l}\text { SUMMARY OUTPUT } \\
\text { Juveniles and LR elevation }\end{array}$} \\
\hline \multicolumn{2}{c}{ Regression Statistics } \\
\hline Multiple R & 0.27 \\
R Square & 0.07 \\
Adjusted R Square & -0.4 \\
Standard Error & 245 \\
Observations & 4 \\
\hline
\end{tabular}

\begin{tabular}{lr}
\multicolumn{2}{l}{ SUMMARY OUTPUT } \\
\multicolumn{2}{l}{ Juveniles vs. Adult returns } \\
\hline \multicolumn{2}{c}{ Regression Statistics } \\
\hline Multiple R & 0.83 \\
R Square & 0.69 \\
Adjusted R Square & 0.53 \\
Standard Error & 142 \\
Observations & 4 \\
\hline
\end{tabular}

\section{Habitat Analysis}

The habitat features analyzed from the data collected include pool and riffle ratios, large woody debris (LWD), substrate composition, bankfull measurements, and shade. These attributes were examined for general trends, comparison to another undisturbed watershed (Westfork Hall Creek, examined in 1999 only) and comparisons to each other.

\section{Pool- Riffle Ratios}

Pool-riffle ratios were examined in every stream segment. Most of the data consist of four years of data: one year (1990 or 1991) before treatments and three years after (1997-1999). This discussion will consider only the $\mathrm{X}$ coefficient in the regression equation for trends. The variance, standard deviation, and standard error in the data will not be discussed due to limited data and high variability (see Table 19). No association, correlation, or connection could be found between streams or stream segments within a given year or between years. Using the $\mathrm{X}$ coefficients a more negative number means the segment has decreased riffle area and increased pool area in the segment over time: pools are the constant in the ratio equaling one, whereas the riffle area is variable, and typically larger (e.g. 1 square meter of pool and 3 of riffle in year one changes to 1 and 2 square meters, respectively, in year two, the $\mathrm{X}$ coefficient (Xc) is negative, but a positive [for management] result). For comparison purposes, structures for habitat improvement were installed in segment one of North and South Nanamkin Creeks and segment two of Blue Creek. All other structures/improvements were for fish passage through culverts only, but all segments were examined for pool-riffle ratios. Two problems that have occurred: 1) it is unknown how much dry channel in any given year occurs as it is not measured, and 2) the end point of the segments in year one was not well defined (applies to Iron Creek, Louie Creek, and segment one in North and South Nanamkin Creeks). The assumption in the analysis is that the lower the ratio, the better the habitat 9more pool area). 


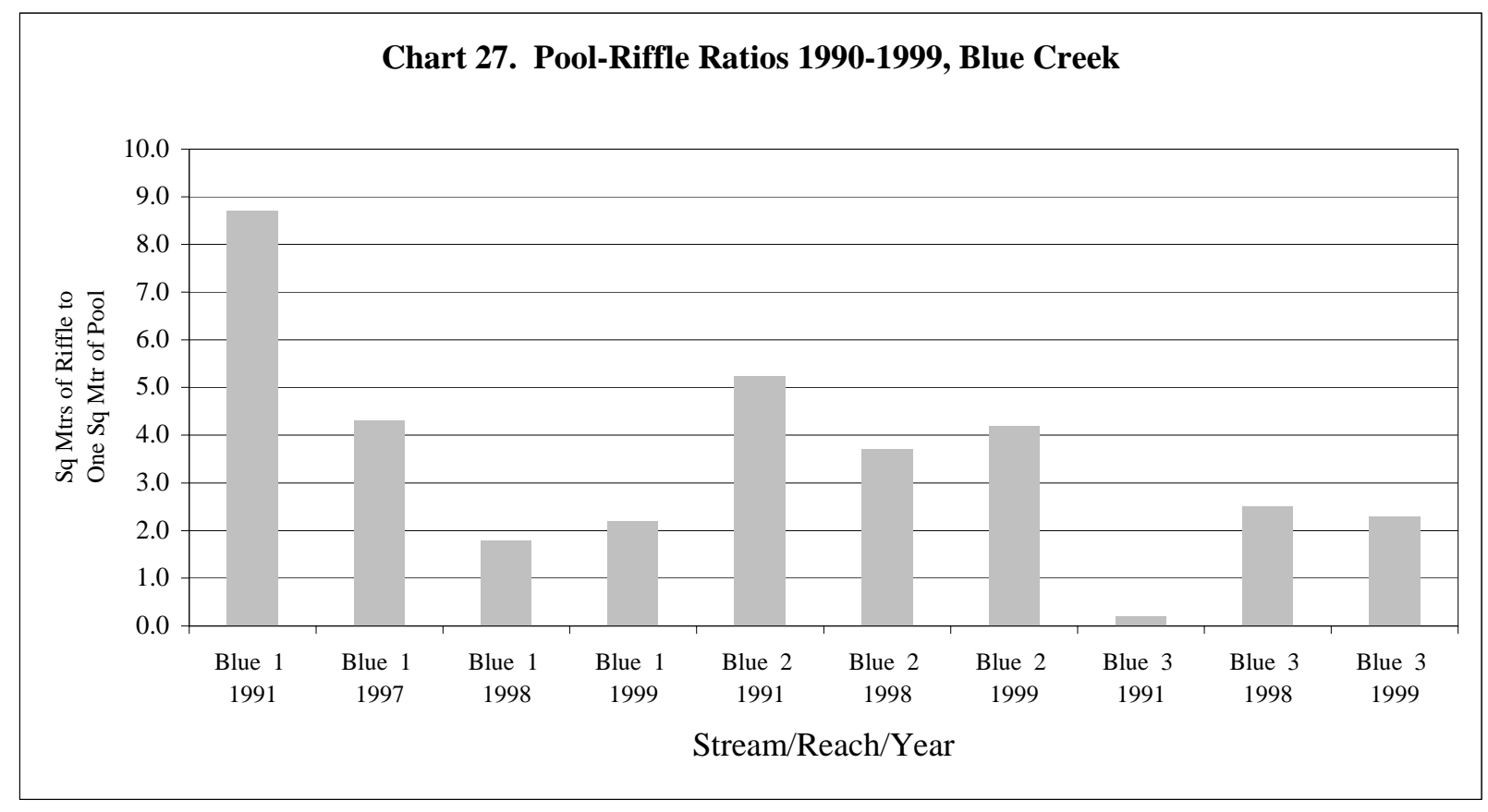

Table 19. X Coefficients from Linear Regression Table 20. Descriptive Statistics of Pool-Riffle Ratio Data.

\begin{tabular}{|l|r|r|l|r|}
\hline Stream/Segment & X coefficient & $\mathbf{n}=$ & Mean & 3.9 \\
\hline Blue Creek 1 & -2.20 & 4 & Standard Error & 0.4 \\
\hline Blue Creek 2 & -0.52 & 3 & Median & 3.6 \\
\hline Blue Creek 3 & 1.05 & 3 & Mode & 2.3 \\
\hline Iron Creek 1 & -1.07 & 4 & Standard Deviation & 2.8 \\
\hline Iron Creek 2 & -2.54 & 4 & Sample Variance & 7.9 \\
\hline Louie Creek 1 & 0.41 & 4 & Kurtosis & 5.4 \\
\hline Louie Creek 2 & 0.86 & 4 & Skewness & 2.0 \\
\hline North Nanamkin Creek 1 & -0.89 & 4 & Range & 14.5 \\
\hline North Nanamkin Creek 2 & -0.70 & 4 & Minimum & 0.2 \\
\hline North Nanamkin Creek 3 & 0.10 & 3 & Maximum & 14.7 \\
\hline South Nanamkin Creek 1 & 0.01 & 4 & Sum & 184.2 \\
\hline South Nanamkin Creek 2 & 2.02 & 3 & Count & 47 \\
\hline South Nanamkin Creek 3 & 1.64 & 3 & Confidence Level(95.0\%) & 0.83 \\
\hline
\end{tabular}



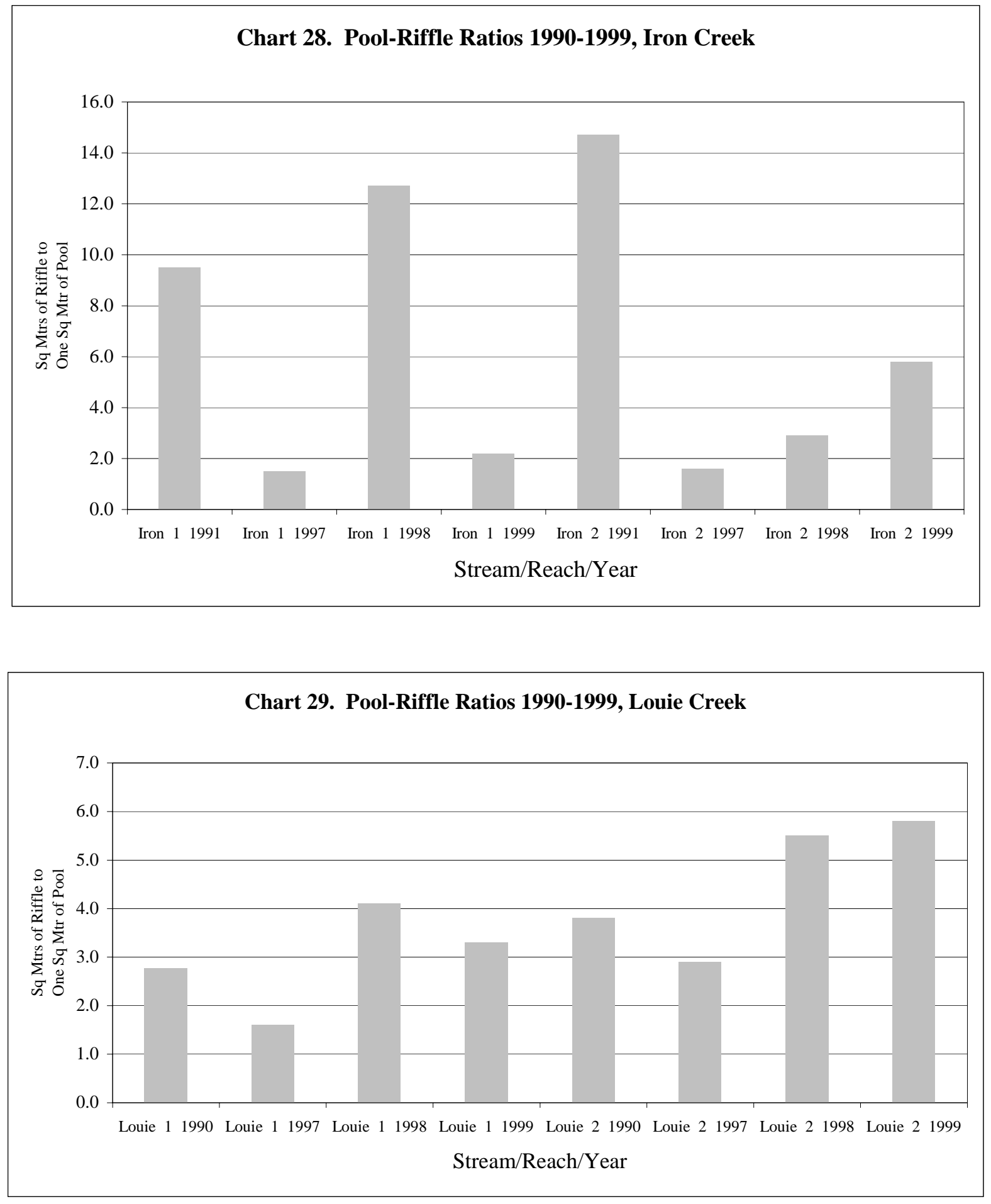

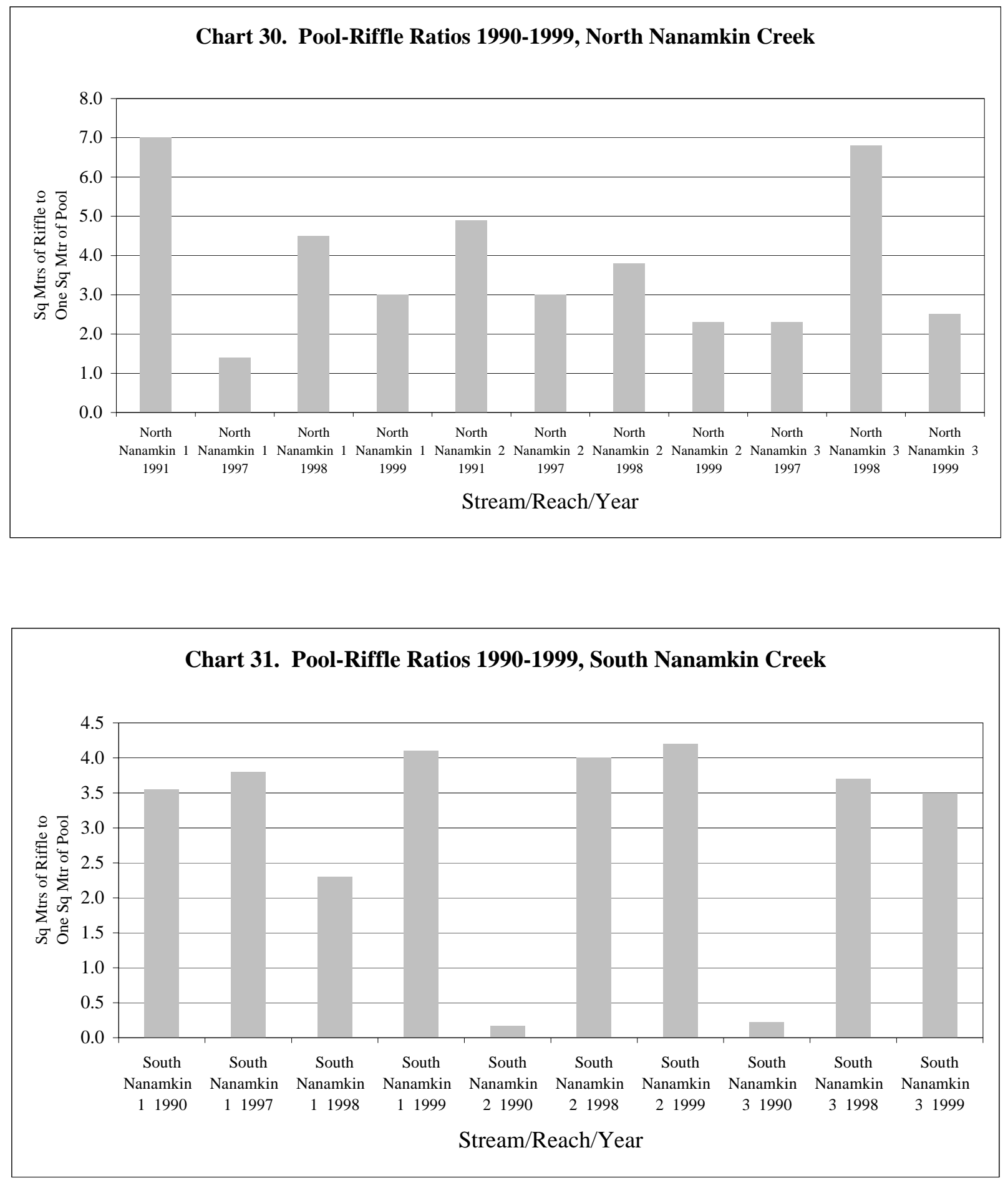
Blue Creek segment one had a substantial improvement in the pool riffle ratio (Table 19), segment 2 (see note above) had a slight improvement and segment three declined. During 1998 and 1999 segment three had only a limited area of habitat surveyed (less that 100 meters). Over 3000 meters were originally surveyed in 1991 and has led to inconclusive results. Iron Creek had a similar difference in sampling in reach one (1189 meters in 1991) comparing 1991with later years. Over 300 meters were surveyed in 1997, 424 in 1998, 560 in 1999, but the end point was in the same place every year in those three years. Segment two had a similar sampling disparity, but may be due to the length of dry channel that existed in the segment. In either case the trend (Xc $=-1.07$ and -2.54 respectively) the data is somewhat inconclusive as the variability in the years for segment one is extreme, and segment two has been on a steady decrease in pool area since 1997 (note that a logging sale started in late 1997 in that watershed and has increased the magnitude of the spring spates). In Louie Creek has had a slight increase in the ratio over time in both segments (decline in pool habitat area): the only year of decreased (increase in pool area) ratio, although slight, was in 1997. North Nanamkin Creek has had an improving trend $\left(\mathrm{Xc}_{\mathrm{c}}=-0.89\right.$ and -0.70 , respectively) in segments one and two, but segment three data shows no real change. Segment three had only a limited area of habitat surveyed (less that 100 meters in 1997, 164 in 1998 and 314 in 1999) and therefore may not show trends readily. South Nanamkin Creek segment one has not changed much over time (Xc= 0.01), but 1999 had the highest ratio (may be due to three structures becoming partially eroded away in spring of 1999). Segment two and three trends show a decline in the quality of habitat (increased ratio), but for 1998 and 1999 are almost identical for both reaches. In the 1999 field season another stream, with little or no disturbance, the West Fork of Hall Creek, was surveyed to compare some of the attributes in habitat characteristics. This stream has no roads in the watershed (one road runs through a corner of the watershed away from any stream channel). The Westfork of Hall Creek has a similar geology and gradient as the other streams. This watershed had a pool- riffle ratio of 1:4.3 (1367 meters were surveyed). The one major difference seen in the pool/riffle habitat was that the average depth was deeper in the pools in the West Fork of Hall Creek compared to all the other stream segments in 1999. For all segments the minimum and maximum pool-riffle ratios were 0.17 and 14.7, respectively, and had a mean of 3.92. Segment one in North Nanamkin had no pools in 1991, therefore had no ratio, but one value (7.0) was inserted to do the trend analysis (a value was needed to make a trend equation).

\section{Large Woody Debris}

Large woody debris (LWD) data were originally taken in 1990-1991, but were not in 1997. The guidelines in 1990-91 were 6 feet or longer, 6 inches or greater in diameter and at least half the length within the bankfull width. In fall of 1998 LWD was incorporated in the survey protocol using similar guidelines used in 1990-1991; 6 feet or longer, 4 inches or greater in diameter and at least half the length within the bankfull width, but was also separated into two categories. One category is 4-10 inches in

diameter, and the second is greater than 10 inches in diameter. Table 20 and charts 32-36 are rates for each segment per mile; many segments are less than a mile long (see Appendix A). 


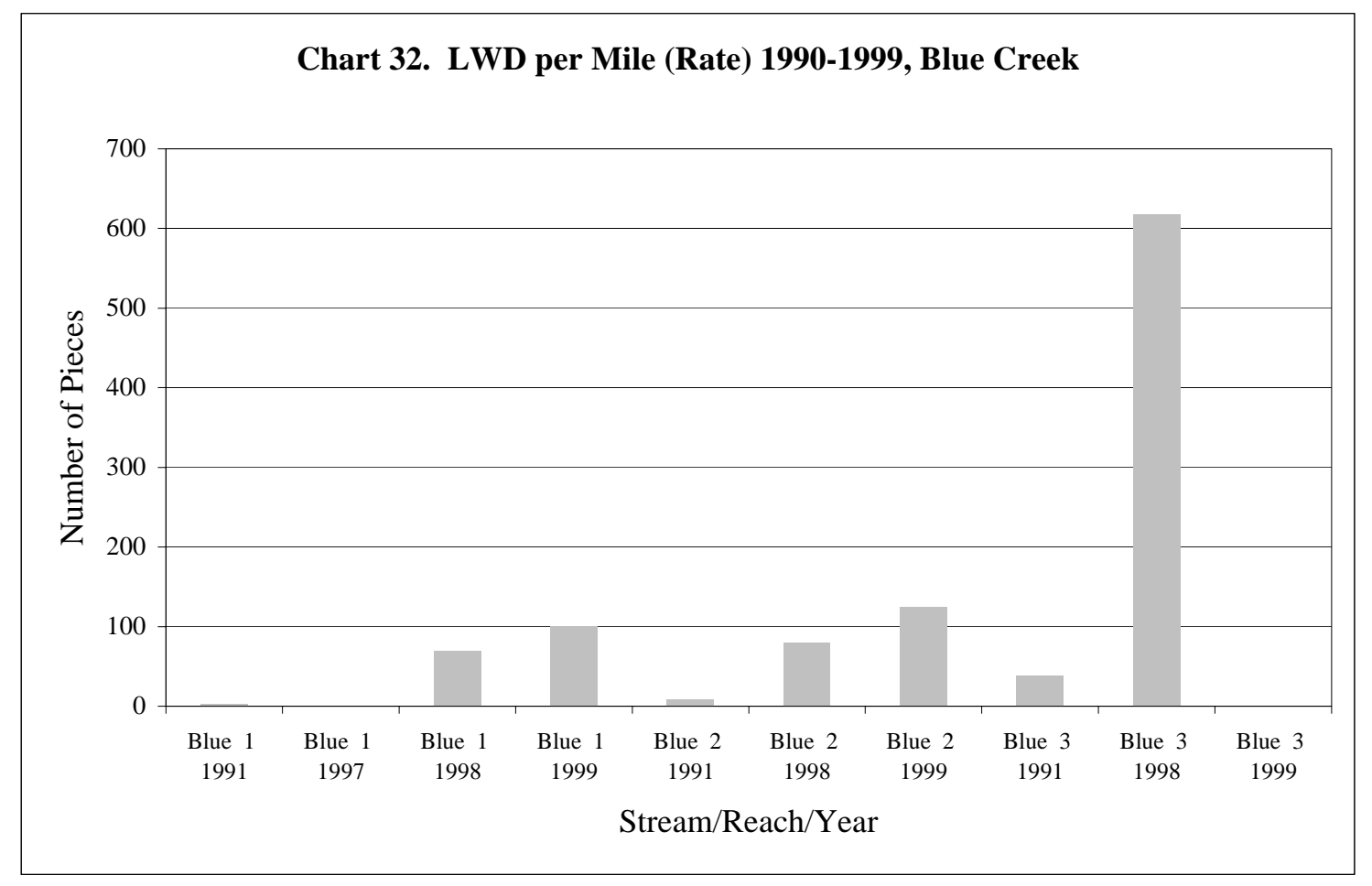

Table 21. Large Woody Debris Counts, All Years.

\begin{tabular}{|c|c|c|c|c|}
\hline Strm/Rch/Yr & LWD4-10 & LWD $>10$ & LWD>6 & Sum LWD/mile \\
\hline Blue 11991 & & & 3 & 3 \\
\hline Blue 11998 & 42 & 27 & & 69 \\
\hline Blue 11999 & 64 & 37 & & 101 \\
\hline Blue 21991 & & & 9 & 9 \\
\hline Blue 21998 & 51 & 30 & & 80 \\
\hline Blue 21999 & 82 & 43 & & 125 \\
\hline Blue 31991 & & & 39 & 39 \\
\hline Blue 31998 & 457 & 161 & & 618 \\
\hline Blue 31999 & & & & 0 \\
\hline Iron 11991 & & & 1 & 1 \\
\hline Iron 11998 & 49 & 8 & & 57 \\
\hline Iron 11999 & 83 & 34 & & 117 \\
\hline Iron 21991 & & & 17 & 17 \\
\hline Iron 21998 & 37 & 26 & & 63 \\
\hline Iron 21999 & 120 & 75 & & 195 \\
\hline Louie 11990 & & & 54 & 54 \\
\hline Louie 11998 & 263 & 119 & & 382 \\
\hline Louie 11999 & 380 & 80 & & 460 \\
\hline Louie 21990 & & & 9 & 9 \\
\hline Louie 21998 & 62 & 31 & & 92 \\
\hline Louie 21999 & 54 & 52 & & 106 \\
\hline North Nanamkin 11991 & & & 0 & 0 \\
\hline North Nanamkin 11998 & 62 & 12 & & 74 \\
\hline
\end{tabular}


Table 21. (continued)

\begin{tabular}{|c|c|c|c|c|}
\hline Strm/Rch/Yr & LWD4-10 & LWD $>10$ & LWD $>6$ & Sum LWD/mile \\
\hline North Nanamkin 11999 & 76 & 20 & & 96 \\
\hline North Nanamkin 21991 & & & 53 & 53 \\
\hline North Nanamkin 21998 & 88 & 42 & & 131 \\
\hline North Nanamkin 21999 & 82 & 55 & & 137 \\
\hline North Nanamkin 31998 & 157 & 49 & & 206 \\
\hline North Nanamkin 31999 & 349 & 185 & & 534 \\
\hline South Nanamkin 11990 & & & 0 & 0 \\
\hline South Nanamkin 11998 & 0 & 0 & & 0 \\
\hline South Nanamkin 11999 & 0 & 7 & & 7 \\
\hline South Nanamkin 21990 & & & 34 & 34 \\
\hline South Nanamkin 21998 & 77 & 37 & & 114 \\
\hline South Nanamkin 21999 & 95 & 57 & & 152 \\
\hline South Nanamkin 31990 & & & 38 & 38 \\
\hline South Nanamkin 31998 & 116 & 84 & & 200 \\
\hline South Nanamkin 31999 & 76 & 47 & & 123 \\
\hline Westfork Hall Ck 11999 & 492 & 276 & & 768 \\
\hline
\end{tabular}

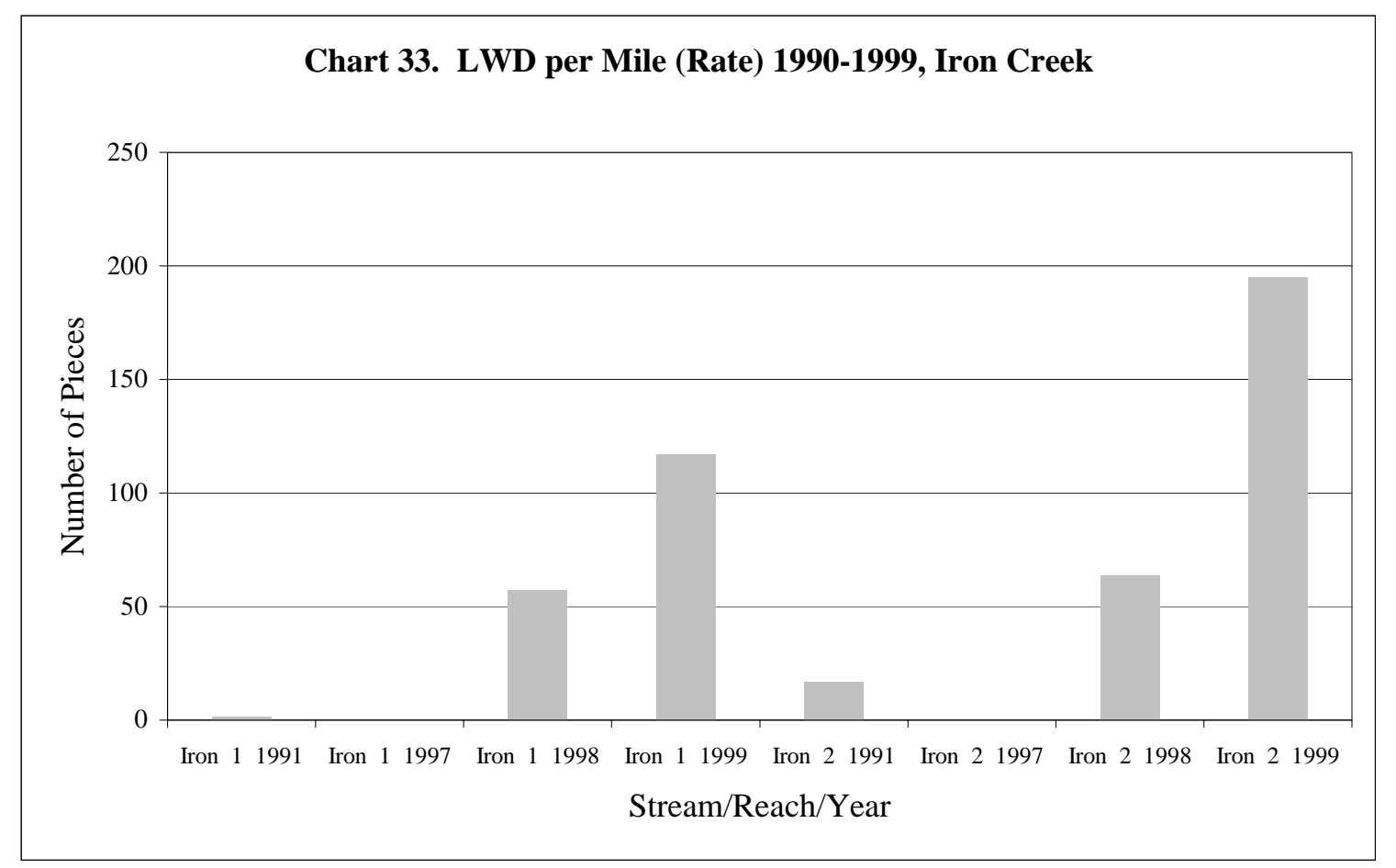



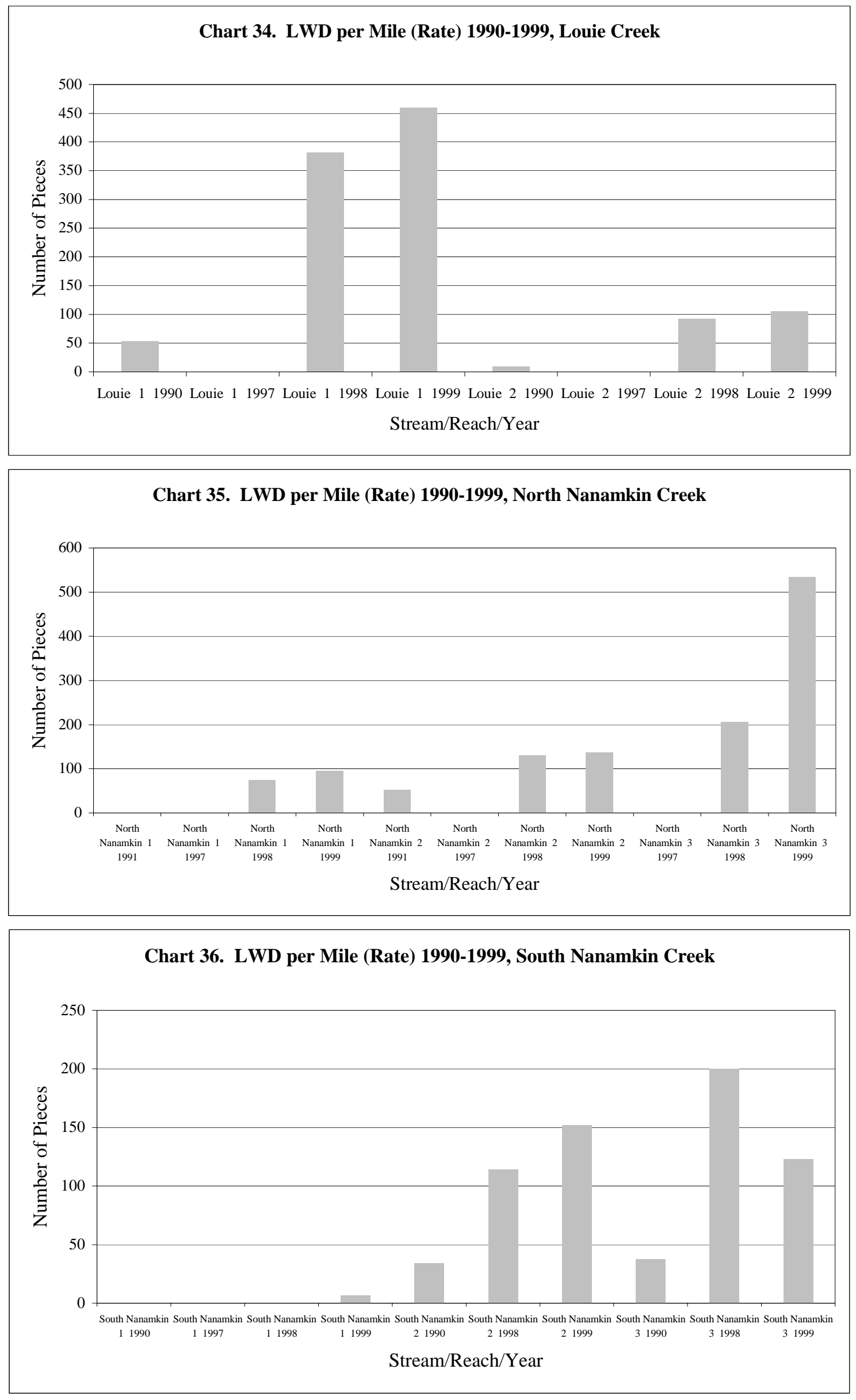
Table 22. X Coefficients from Linear Regression

Table 23. Descriptive Statistics for Sum LWD/mile

\begin{tabular}{|l|r|r|l|r|}
\hline Stream/Segment & X coefficient & $\mathbf{n}=$ & Mean & 135.0 \\
\hline Blue Creek 1 & 49.2 & 3 & Standard Error & 28.6 \\
\hline Blue Creek 2 & 58.2 & 3 & Median & 80.2 \\
\hline Blue Creek 3 & 19.5 & 3 & Mode & 0 \\
\hline Iron Creek 1 & 57.8 & 3 & Standard Deviation & 178.8 \\
\hline Iron Creek 2 & 89.2 & 3 & Sample Variance & 31958.2 \\
\hline Louie Creek 1 & 203.2 & 3 & Kurtosis & 4.6 \\
\hline Louie Creek 2 & 48.4 & 3 & Skewness & 2.2 \\
\hline North Nanamkin Creek 1 & 48.0 & 3 & Range & 768 \\
\hline North Nanamkin Creek 2 & 42.1 & 3 & Minimum & 0 \\
\hline North Nanamkin Creek 3 & & 2 & Maximum & 768 \\
\hline South Nanamkin Creek 1 & 3.5 & 3 & Sum & 5263.5 \\
\hline South Nanamkin Creek 2 & 59.0 & 3 & Count & 39 \\
\hline South Nanamkin Creek 3 & 42.7 & 3 & Confidence Level(95.0\%) & 58.0 \\
\hline
\end{tabular}

The $\mathrm{X}$ coefficient $(\mathrm{Xc})$ in the regression equation (slope) for trends and descriptive statistics are used for the discussion on large woody debris. The variance, standard deviation, and standard error in the data will not be discussed as there are only three data points, and it is expected that these numbers are highly variable. The survey length problems discussed in the pool-riffle section apply in this and the following section as well. The data showed all stream segments in every stream have increased in the amount of LWD over the three-year period. The LWD in Blue Creek has steadily increased over time in segment one and two. Segment three shows a slight increase, but LWD was not counted in 1999 due to time constraints and depicts a value of zero. Iron Creek shows very large increases in the amount of LWD in both segments (Xc= 57.8 and 89.2, respectively). Louie Creek, segment one, had an exceptionally high Xc of 203.2 and segment two was 48.4. The high number of pieces counted in segment one in 1998 and 1999 compared to 1990 seems unusual, but the only event that has taken place in from 1990 to 1998 is a the extreme flooding in 1996 and 1997, which may have influenced these increases. The increase of LWD in segment one in North Nanamkin Creek is in the upper end and is probably from cottonwood trees damaged in storms in 1996 and 1997. These trees continue to drop large limbs in the stream. Also, several coniferous trees have fallen from wind and water soaked soils in the spring. Segment two has increased as well; segment three has only two years of data (1998 and 1999) and could not be analyzed. In South Nanamkin Creek, segment one has not changed much. Very few large trees exist around this segment and those counted most recently are mostly LWD from structures installed by this project. The other segments are similar to North Nanamkin Creek increases.

Another comparison that was made is the frequency of LWD (per mile) between the streams and between segments within a stream. The mean and median value of all segments, including West Fork Hall Creek, is 135 and 80 pieces respectively. The high, WF Hall, was a rate of 768 pieces per mile (1999), and a low of zero (segment one in North and South Nanamkin Creeks, in 1991 and 1990 respectively). Of all the segments, segment one in North and South Nanamkin Creeks are the most altered from historical conditions (livestock grazing and land conversion to agriculture). The other highest rates of LWD were in the lower segment of Louie Creek and the upper most segment of North Nanamkin Creek (Blue Creek segment three was too short of a survey and is considered biased). The trend of LWD per mile increases, as a general rule, in the surveys going upstream I the watersheds, with the exception of Louie Creek, in all years.

\section{Substrate}

Pebble counts were incorporated back into the surveys in 1998; 100 or greater total count, conducted perpendicular to stream flow, and as transects within habitat units that were electroshocked for fish population estimates (therefore the number of samples is equal to that of the electroshocked units[Table 11]). Substrate categories are as follows: $0-0.6 \mathrm{~mm}$ is sand, $0.6 \mathrm{~mm}-10 \mathrm{~cm}$ gravel, $10 \mathrm{~cm}-30 \mathrm{~cm}$ cobble, $>30 \mathrm{~cm}$ boulder and bedrock (see Table 21). An analysis was done to determine if there is a relationship of 
substrate, and other parameters, to fish density in pools and riffles using regression (using the 1998 data set; see 1998 annual report). The best fit for any parameter examined was poor (the best $r^{2}$ was 0.45 when fish density was compared to pool area; substrate compared with fish density was less than a 0.10 value). In 1990-1991 substrate counts were done, but the methodology was inconsistent; most were done counting the types of substrate encountered moving upstream in a reference section, but not as transects across the stream channel (the protocol is not clear). Nevertheless, a comparison has been done to compare any differences between the years using the sand substrate category and some comparisons between pools and riffles has been done in 1998 and 1999.

Table 25. X Coefficients from Linear Regression Table 26. Descriptive Statistics for Sand Substrate

\begin{tabular}{|l|r|r|l|r|}
\hline Stream/Segment & X coefficient & $\mathbf{n}=$ & Mean & 16.6 \\
\hline Blue Creek 1 & 2.0 & 3 & Standard Error & 1.8 \\
\hline Blue Creek 2 & 5.0 & 3 & Median & 14 \\
\hline Blue Creek 3 & & 2 & Mode & 5 \\
\hline Iron Creek 1 & -6.5 & 3 & Standard Deviation & 11.2 \\
\hline Iron Creek 2 & -5.0 & 3 & Sample Variance & 125.4 \\
\hline Louie Creek 1 & 0.0 & 3 & Kurtosis & -1.1 \\
\hline Louie Creek 2 & 5.0 & 3 & Skewness & 0.4 \\
\hline North Nanamkin Creek 1 & 12.5 & 3 & Range & 38 \\
\hline North Nanamkin Creek 2 & 9.0 & 3 & Minimum & 0 \\
\hline North Nanamkin Creek 3 & & 2 & Maximum & 38 \\
\hline South Nanamkin Creek 1 & -4.0 & 3 & Sum & 613.5 \\
\hline South Nanamkin Creek 2 & 2.5 & 3 & Count & 37 \\
\hline South Nanamkin Creek 3 & 0.0 & 3 & Confidence Level(95.0\%) \\
\hline
\end{tabular}

It does not appear that any stream has any significant changes in the amount of sand in the substrate composition based on the $\mathrm{X}$ coefficient of the regression equation. North Nanamkin Creek segment one has had the highest slope of 12.0 (increase in sand percent), and the recent (1-2 years) logging activity and hydrologic events may be responsible for that increase. Segment two had and Xc of 9.0, but it was reported that this segment had zero percent fines in 1991 and that is likely to have been underestimated. Iron Creek conversely has had a decrease in both segments and has also had logging activity in 1997-1999.

In 1998 and 1999 pool and riffle substrate composition were analyzed separately. The general trend was that pools had higher fines than the riffles, but over the two years there were several instances (samples) that was not true or nearly even (two in 1999, and five in 1998, out of 12 total). During the twoyear period only two cases exceeded 35 percent fines. Those instances occurred in the pools in Blue and Iron Creek. 


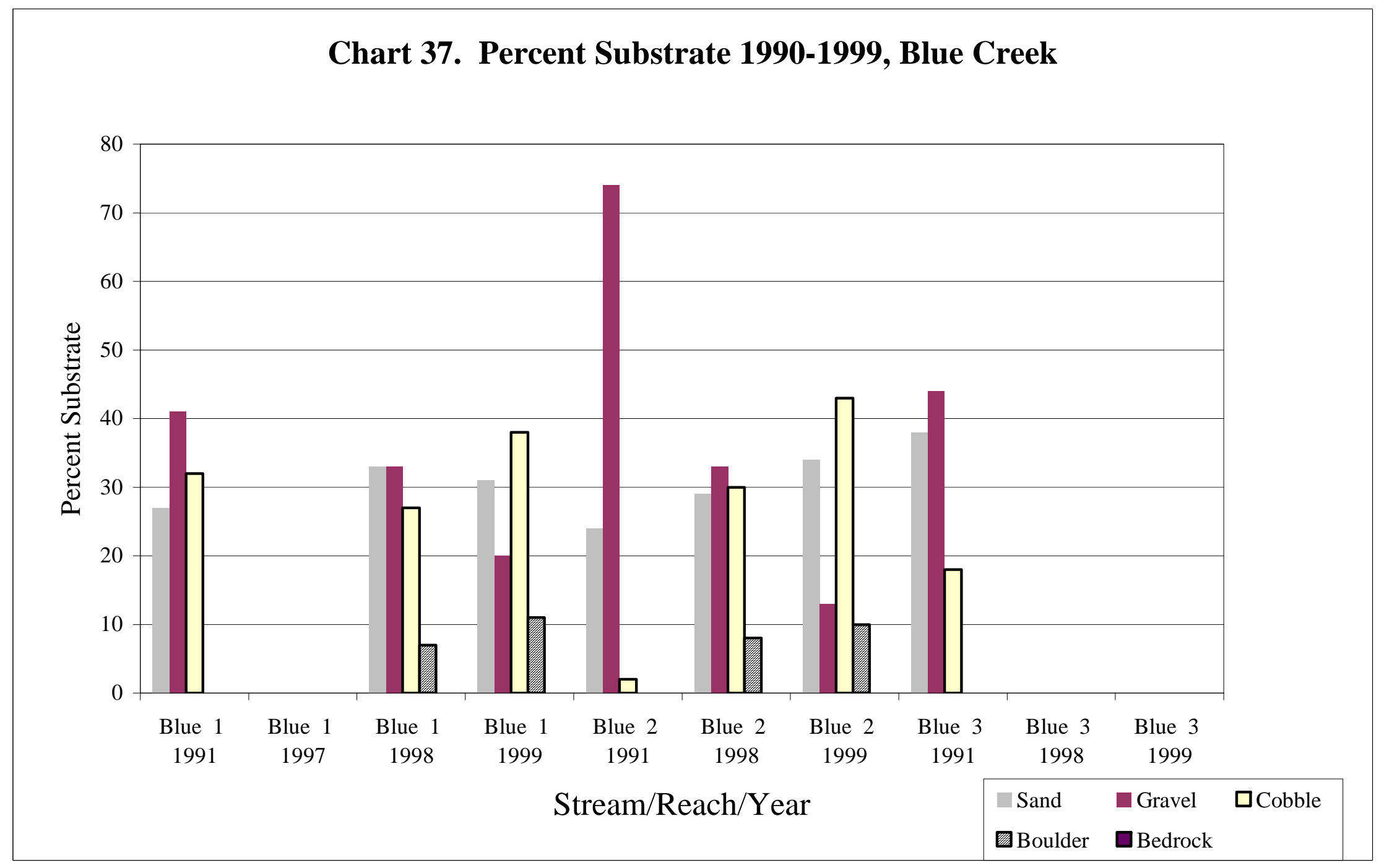




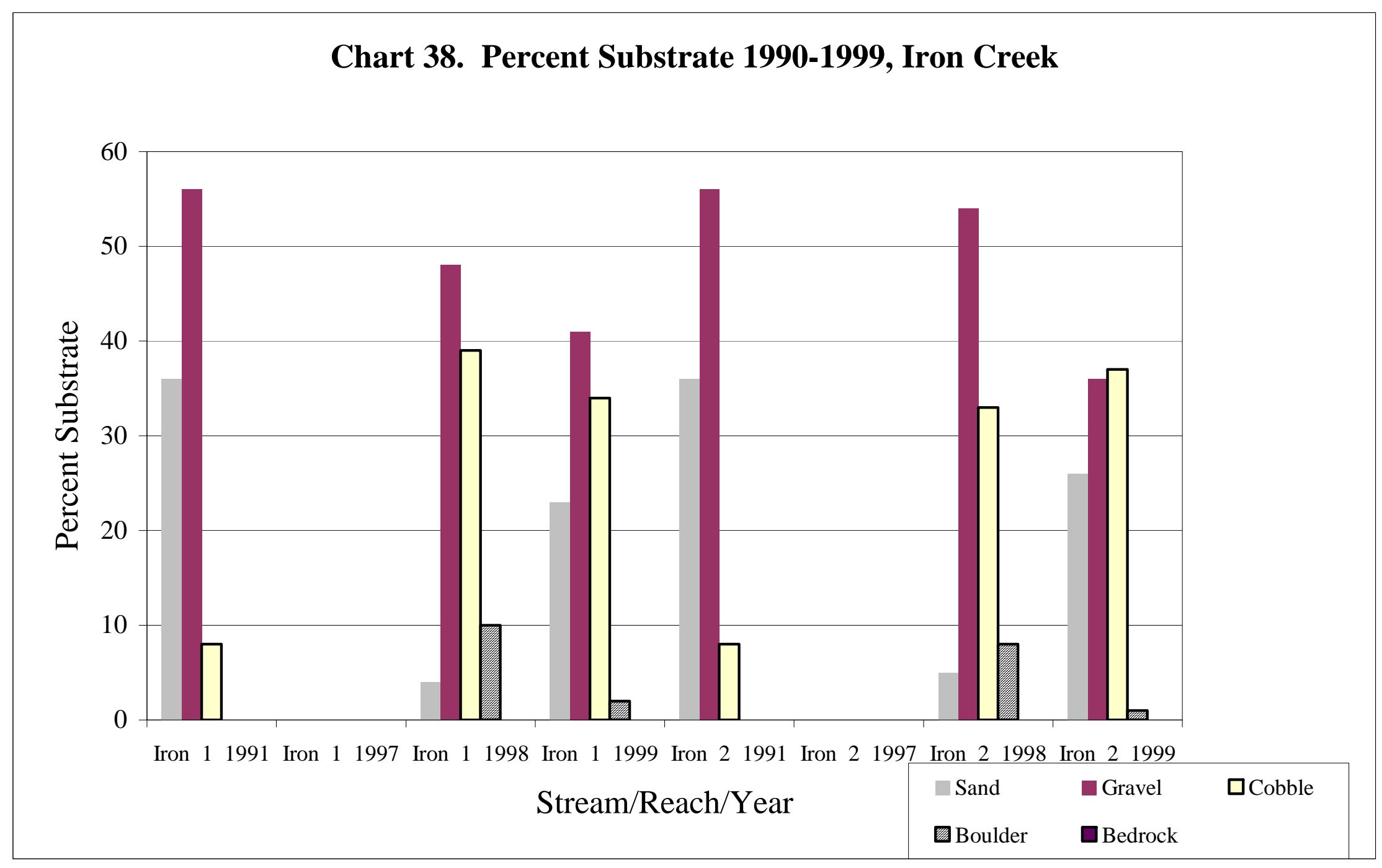




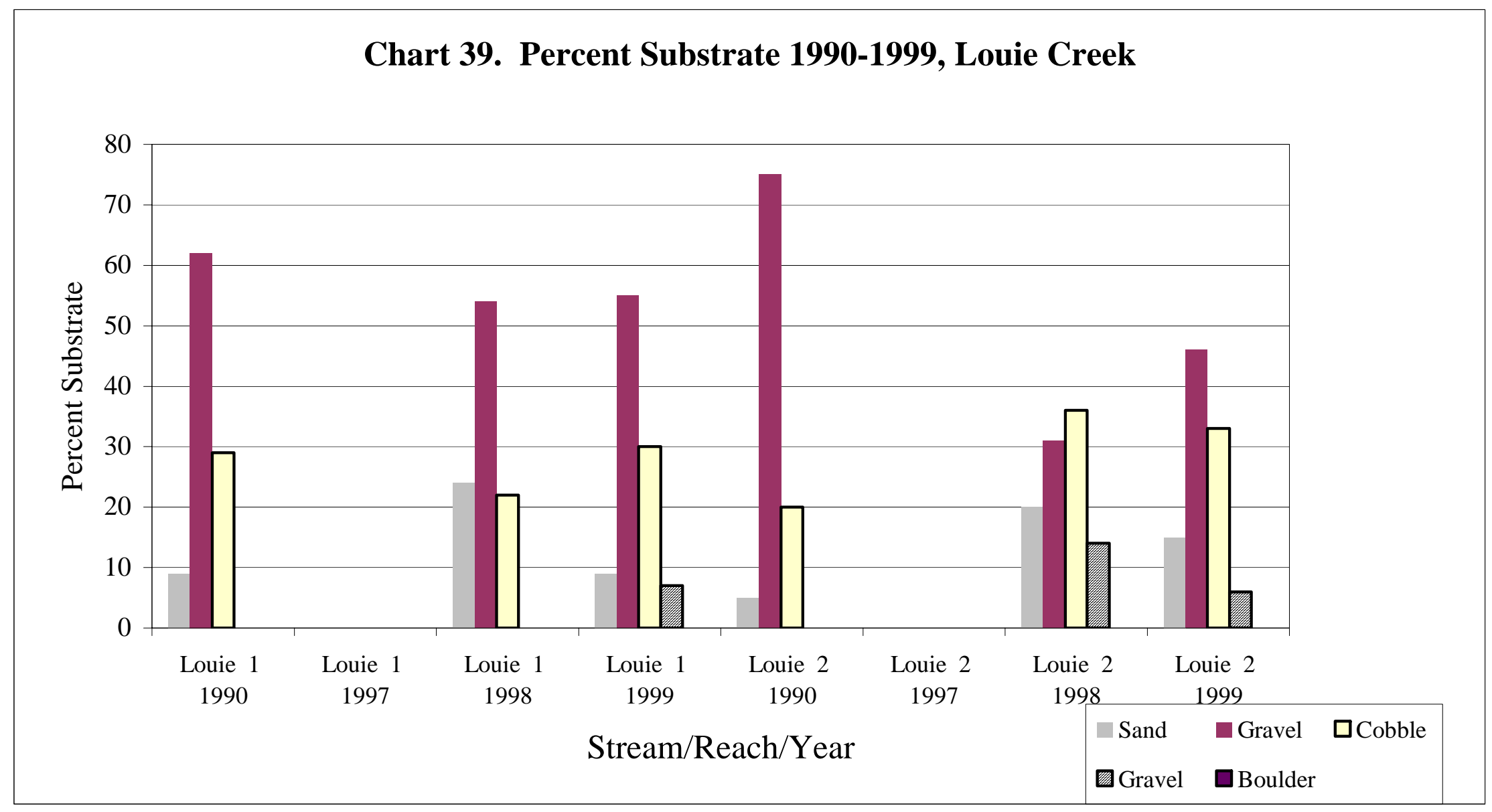




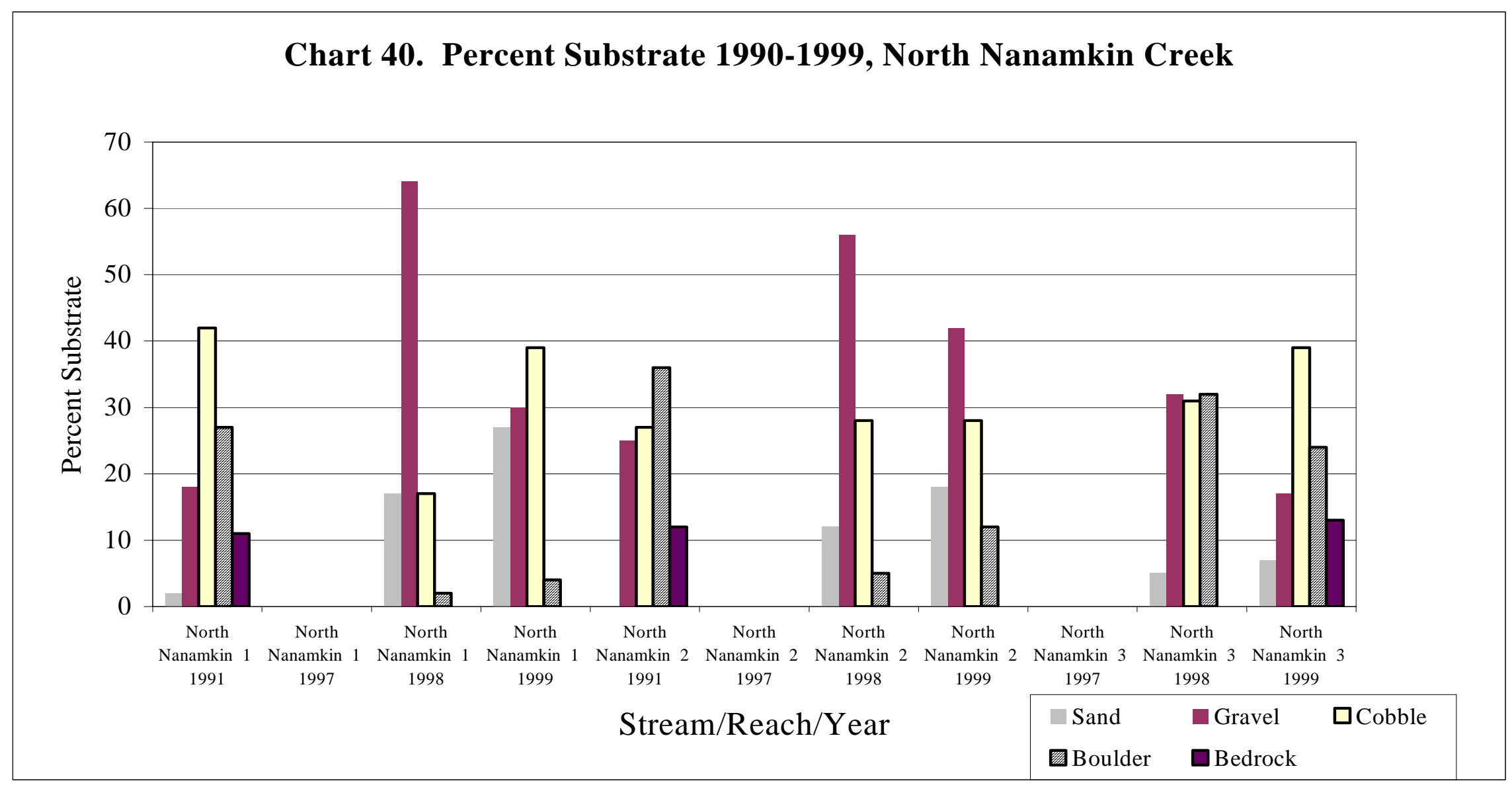




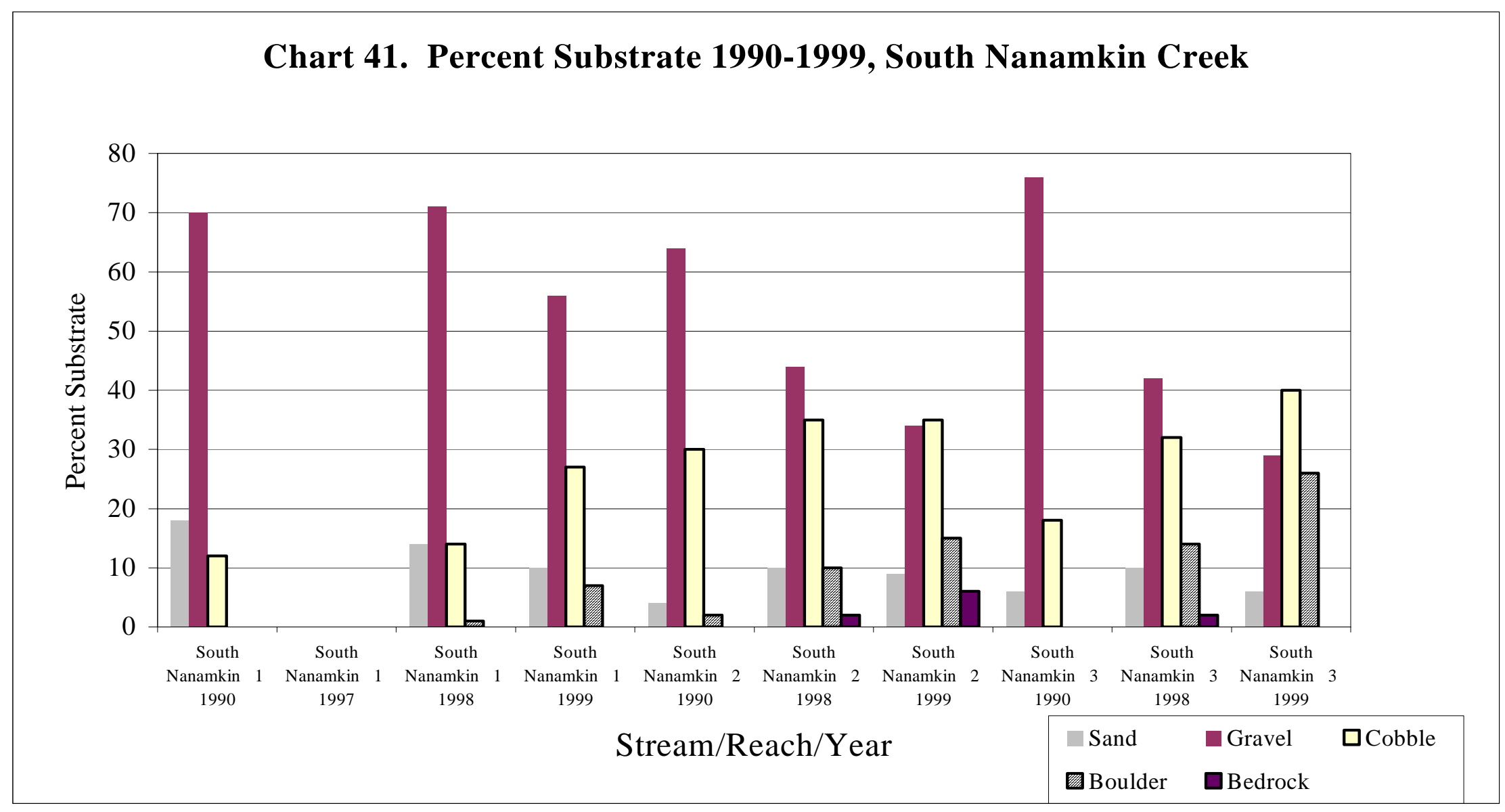


Table 27. Substrate survey results 1999.

\begin{tabular}{|c|c|c|c|c|c|}
\hline Stream & Percent Sand & Gravel & Cobble & Boulder & Bedrock \\
\hline Blue Creek VS1 & 30.9 & 19.6 & 38.4 & 11.1 & \\
\hline Pools Only & 45 & 12 & 36 & 8 & \\
\hline Riffles Only & 20 & 26 & 40 & 14 & \\
\hline Blue Creek VS2 & 34.1 & 13.2 & 42.9 & 9.8 & \\
\hline $\begin{array}{l}\text { Pools Only } \\
\end{array}$ & 64 & 6 & 30 & 0 & \\
\hline Riffles Only & 19 & 17 & 49 & 15 & \\
\hline \multicolumn{6}{|l|}{ Blue Creek VS3 } \\
\hline Iron Creek VS1 & 23.3 & 412 & 339 & 16 & \\
\hline Pools Only & 24 & 45 & 28 & 2.7 & \\
\hline Riffles Only & 22 & 36 & 42 & 0 & \\
\hline Iron Creek VS2 & 26.0 & 35.9 & 36.6 & 1.4 & \\
\hline Pools Only & 43 & 30 & 44 & 0 & \\
\hline Riffles Only & 13 & 40 & 27 & 2.5 & \\
\hline Louie Creek VS1 & 8.7 & 54.8 & 29.7 & 6.7 & \\
\hline $\begin{array}{l}\text { Pools Only } \\
\end{array}$ & 13 & 59 & 28 & 0 & \\
\hline Riffles Only & 3 & 48 & 32 & 17 & \\
\hline Louie Creek VS2 & 14.9 & 46.2 & 33.3 & 5.6 & \\
\hline Pools Only & 19 & 52 & 23 & 6.3 & \\
\hline Riffles Only & 7 & 36 & 53 & 4.2 & \\
\hline North Nanamkin VS1 & 26.5 & 30.4 & 39.2 & 3.9 & \\
\hline $\begin{array}{l}\text { Pools Only } \\
\end{array}$ & 34 & 33 & 30 & 3 & \\
\hline Riffles Only & 19 & 28 & 48 & 5 & \\
\hline North Nanamkin VS2 & 17.8 & 42.0 & 27.9 & 12.3 & \\
\hline $\begin{array}{l}\text { Pools Only } \\
\end{array}$ & 25 & 39 & 30 & 6 & \\
\hline Riffles Only & 8 & 46 & 26 & 20 & \\
\hline North Nanamkin VS3 & 6.8 & 17.3 & 39.2 & 24.0 & 12.7 \\
\hline $\begin{array}{l}\text { Pools Only } \\
\end{array}$ & 7 & 15 & 43 & 36 & \\
\hline Riffles Only & 7 & 20 & 36 & 12 & 25 \\
\hline South Nanamkin VS1 & 10.1 & 56.3 & 27.1 & 6.5 & \\
\hline $\begin{array}{l}\text { Pools Only } \\
\end{array}$ & 8 & 50 & 29 & 13 & \\
\hline Riffles Only & 11 & 60 & 26 & 3 & \\
\hline South Nanamkin VS2 & 9.3 & 34.9 & 35.1 & 15.2 & 5.5 \\
\hline $\begin{array}{l}\text { Pools Only } \\
\end{array}$ & 14 & 36 & 30 & 13 & 8 \\
\hline Riffles Only & 2 & 33 & 45 & 19 & 1.3 \\
\hline South Nanamkin VS3 & 5.7 & 28.9 & 39.8 & 25.6 & \\
\hline $\begin{array}{l}\text { Pools Only } \\
\end{array}$ & 10 & 34 & 34 & 22 & \\
\hline Riffles Only & 2 & 25 & 45 & 28 & \\
\hline
\end{tabular}


Table 28. Substrate survey results 1998.

\begin{tabular}{|c|c|c|c|c|c|}
\hline Stream & Percent Sand & Gravel & Cobble & Boulder & Bedrock \\
\hline Blue Creek VS1 & 32.7 & 33.4 & 27.3 & 6.5 & 0 \\
\hline Pools Only & 45 & 33 & 17 & 9 & 0 \\
\hline Riffles Only & 16 & 34 & 41 & 5 & 0 \\
\hline Blue Creek VS2 & 28.9 & 33.2 & 30.0 & 8.0 & 0 \\
\hline $\begin{array}{l}\text { Pools Only } \\
\end{array}$ & 37 & 36 & 23 & 4 & 0 \\
\hline Riffles Only & 22 & 31 & 35 & 11 & 0 \\
\hline Blue Creek VS3 & No Data & & & & \\
\hline Iron Creek VS1 & 3.8 & 47.6 & 39.0 & 9.5 & 0 \\
\hline Pools Only & & & & & \\
\hline Riffles Only & 3.8 & 47.6 & 39.0 & 9.5 & 0 \\
\hline Iron Creek VS2 & 4.9 & 54.2 & 32.8 & 8.0 & 0 \\
\hline Pools Only & 4 & 48 & 37 & 7 & 0 \\
\hline Riffles Only & 5 & 57 & 31 & 10 & 0 \\
\hline Louie Creek VS1 & 24.0 & 54.1 & 21.9 & 0 & 0 \\
\hline Pools Only & 31 & 56 & 34 & 0 & 0 \\
\hline Riffles Only & 15 & 51 & 13 & 0 & 0 \\
\hline Louie Creek VS2 & 20.3 & 30.5 & 35.5 & 13.7 & 0 \\
\hline Pools Only & 35 & 40 & 20 & 5 & 0 \\
\hline Riffles Only & 11 & 24 & 46 & 19 & 0 \\
\hline North Nanamkin VS1 & 17.1 & 64.2 & 16.5 & 2.3 & 0 \\
\hline Pools Only & 17 & 61 & 18 & 5 & 0 \\
\hline Riffles Only & 17 & 68 & 15 & 0 & 0 \\
\hline North Nanamkin VS2 & 11.5 & 55.8 & 28.0 & 4.8 & 0 \\
\hline $\begin{array}{l}\text { Pools Only } \\
\end{array}$ & 16 & 55 & 25 & 4 & 0 \\
\hline Riffles Only & 7 & 57 & 31 & 5 & 0 \\
\hline North Nanamkin VS3 & 4.7 & 32.1 & 31.2 & 32.0 & 0 \\
\hline $\begin{array}{l}\text { Pools Only } \\
\end{array}$ & 5 & 28 & 26 & 41 & 0 \\
\hline Riffles Only & 4 & 37 & 37 & 23 & 0 \\
\hline South Nanamkin VS1 & 13.9 & 70.8 & 14.3 & 0.9 & 0 \\
\hline $\begin{array}{l}\text { Pools Only } \\
\end{array}$ & 20 & 67 & 12 & 2 & 0 \\
\hline Riffles Only & 9 & 74 & 17 & 0 & 0 \\
\hline South Nanamkin VS2 & 10.1 & 43.6 & 34.6 & 10.0 & 1.7 \\
\hline $\begin{array}{l}\text { Pools Only } \\
\end{array}$ & 12 & 48 & 29 & 10 & 2 \\
\hline Riffles Only & 8 & 38 & 43 & 10 & 2 \\
\hline South Nanamkin VS3 & 10.4 & 41.5 & 32.4 & 14.3 & 1.5 \\
\hline Pools Only & 10 & 42 & 30 & 16 & 1.7 \\
\hline Riffles Only & 10 & 40 & 37 & 12 & 1 \\
\hline
\end{tabular}




\section{Bankfull Width-Depth Ratio}

It appears that some streams have significant changes in the width/depth ratio since 1990-1991, although the $\mathrm{X}$ coefficient of the regression equation is not all that high. For example, the ratio for segment one on Blue Creek has nearly doubled since the 1997 measurement and segment two has quadrupled since 1991. Hydrologic events may be responsible for these increases in width/depth ratios. The general trend is that the widths are wider than in 1990-1991, but most streams have a lower ratio in 1999 versus 1998.

The undisturbed watershed, West Fork of Hall Creek, has nearly the mean of all values for width/depth ratios at 17.5 (mean ratio of all streams combined is 17.9 , median 17.3 ).

Table 29. Width-Depth Ratio, All Years.

\begin{tabular}{|c|c|c|c|c|c|}
\hline Strm/Rch/Yr & W/D & Strm/Rch/Yr & W/D & Strm/Rch/Yr & W/D \\
\hline Blue 11991 & 9.4 & Iron 11991 & 5.8 & Louie 11990 & 7.7 \\
\hline Blue 11997 & 9.3 & Iron 11997 & 15.0 & Louie 11997 & 36.0 \\
\hline Blue 11998 & 11.2 & Iron 11998 & 29.0 & Louie 11998 & 15.0 \\
\hline Blue 11999 & 18.7 & Iron 11999 & 15.2 & Louie 11999 & \\
\hline Blue 21991 & 5.2 & Iron 21991 & 9.0 & Louie 21990 & 6.4 \\
\hline Blue 21998 & 13.0 & Iron 21997 & 15.5 & Louie 21997 & 18.5 \\
\hline Blue 21999 & 20.1 & Iron 21998 & 17.8 & Louie 21998 & 15.7 \\
\hline Blue 31991 & 9.3 & Iron 21999 & 17.5 & Louie 21999 & \\
\hline North Nanamkin 11991 & 6.0 & South Nanamkin 11990 & 11.5 & & \\
\hline North Nanamkin 11997 & 25.5 & South Nanamkin 11997 & 27.0 & & \\
\hline North Nanamkin 11998 & 48.0 & South Nanamkin 11998 & 22.5 & & \\
\hline North Nanamkin 11999 & 25.9 & South Nanamkin 11999 & 25.5 & & \\
\hline North Nanamkin 12000 & 24.7 & South Nanamkin 12000 & 20.7 & & \\
\hline North Nanamkin 21991 & 8.4 & South Nanamkin 21990 & 17.0 & & \\
\hline North Nanamkin 21997 & 20.4 & South Nanamkin 21998 & 26.5 & & \\
\hline North Nanamkin 21998 & 23.7 & South Nanamkin 21999 & 20.7 & & \\
\hline North Nanamkin 21999 & 31.4 & South Nanamkin 31990 & 9.1 & & \\
\hline North Nanamkin 22000 & 31.4 & South Nanamkin 31998 & 26.0 & & \\
\hline North Nanamkin 31997 & 14.1 & South Nanamkin 31999 & & & \\
\hline North Nanamkin 31998 & 25.0 & Westfork Hall Ck 11999 & 17.5 & & \\
\hline North Nanamkin 31999 & & & & & \\
\hline
\end{tabular}

Table 30. X Coefficients from Linear Regression Table 31. Descriptive Statistics for Width-Depth Ratio

\begin{tabular}{|l|r|r|l|r|}
\hline Stream/Segment & X coefficient & $\mathbf{n}=$ & Mean & 17.9 \\
\hline Blue Creek 1 & 3.0 & 4 & Standard Error & 1.4 \\
\hline Blue Creek 2 & 7.5 & 3 & Median & 17.3 \\
\hline Blue Creek 3 & & 2 & Mode & 15 \\
\hline Iron Creek 1 & 4.2 & 4 & Standard Deviation & 9.1 \\
\hline Iron Creek 2 & 2.8 & 4 & Sample Variance & 82.5 \\
\hline Louie Creek 1 & 3.7 & 3 & Kurtosis & 1.5 \\
\hline Louie Creek 2 & 4.6 & 3 & Skewness & 1.0 \\
\hline North Nanamkin Creek 1 & 8.2 & 4 & Range & 42.8 \\
\hline North Nanamkin Creek 2 & 7.2 & 4 & Minimum & 5.2 \\
\hline North Nanamkin Creek 3 & & 2 & Maximum & 48 \\
\hline South Nanamkin Creek 1 & 3.8 & 4 & Sum & 751.7 \\
\hline South Nanamkin Creek 2 & 1.8 & 3 & Count & 42 \\
\hline South Nanamkin Creek 3 & & 2 & Confidence Level(95.0\%) & 2.83 \\
\hline
\end{tabular}




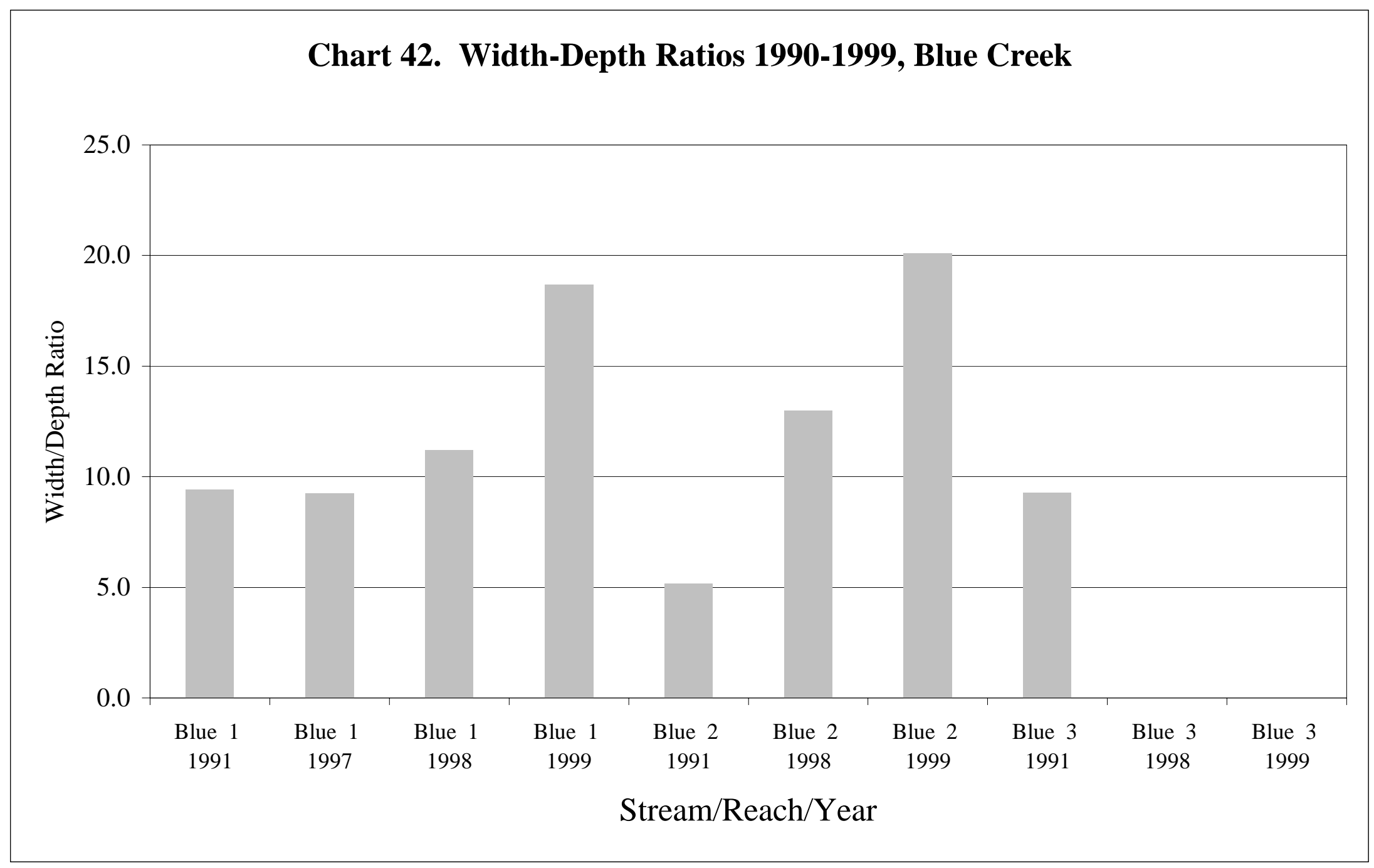




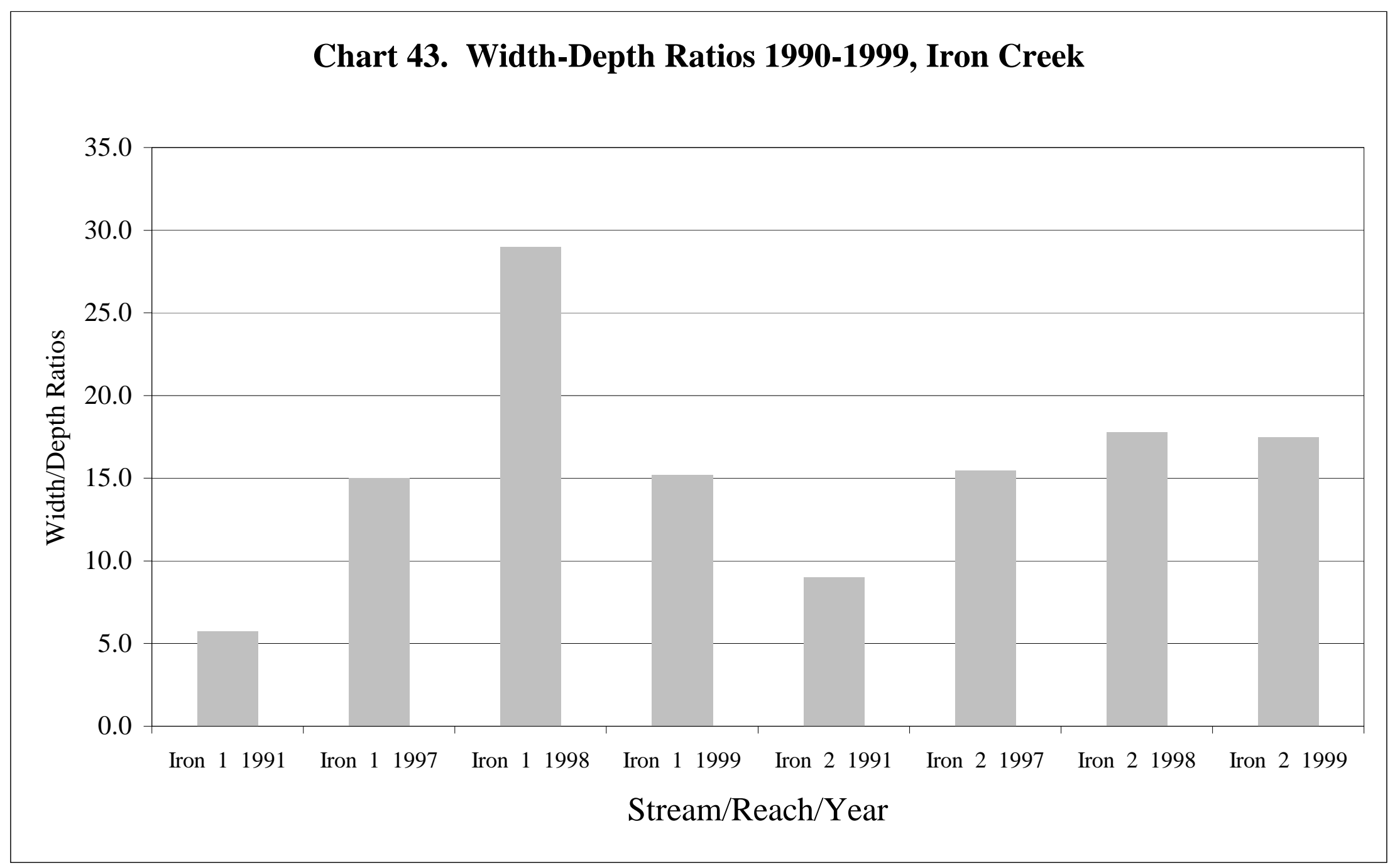




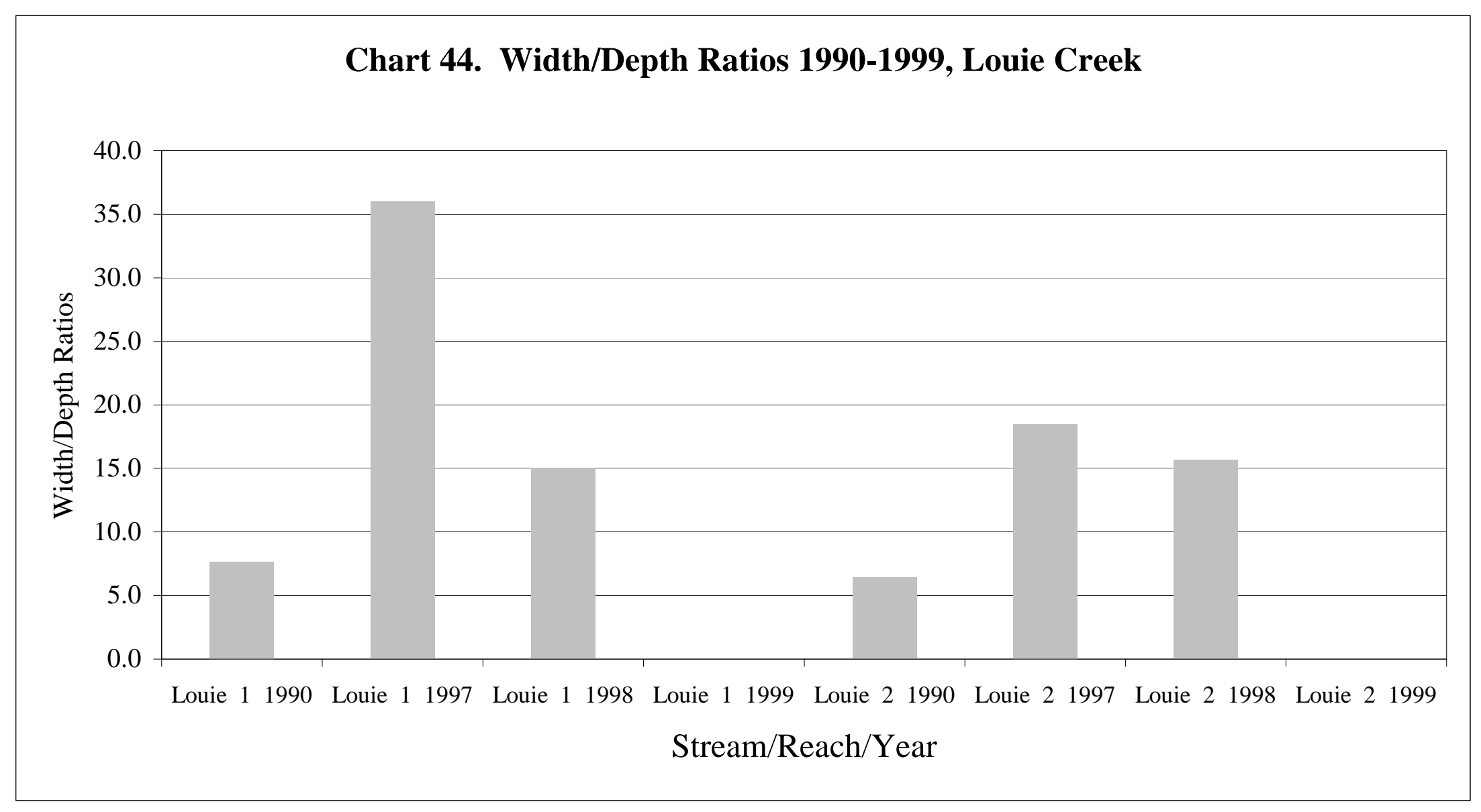




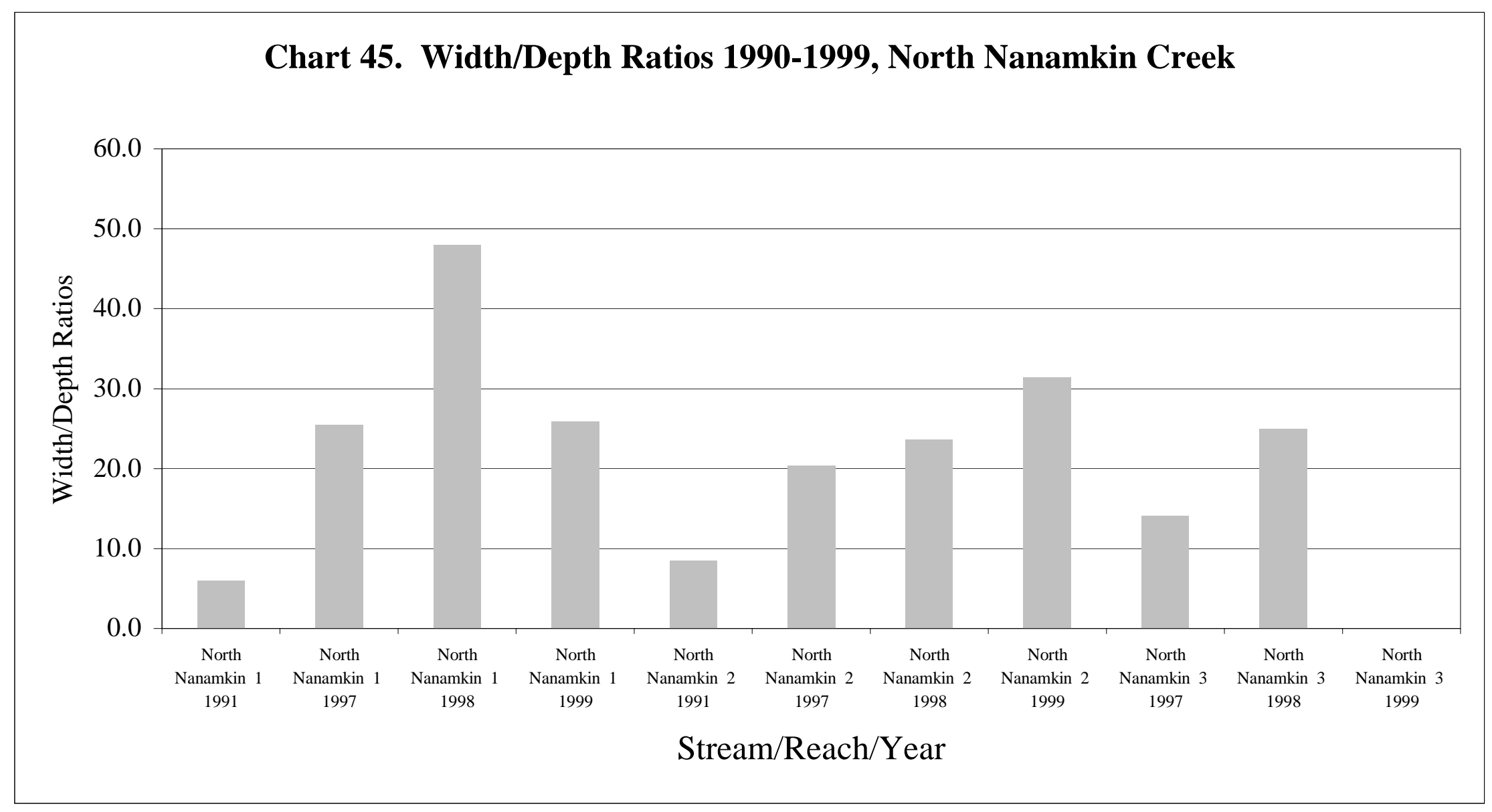




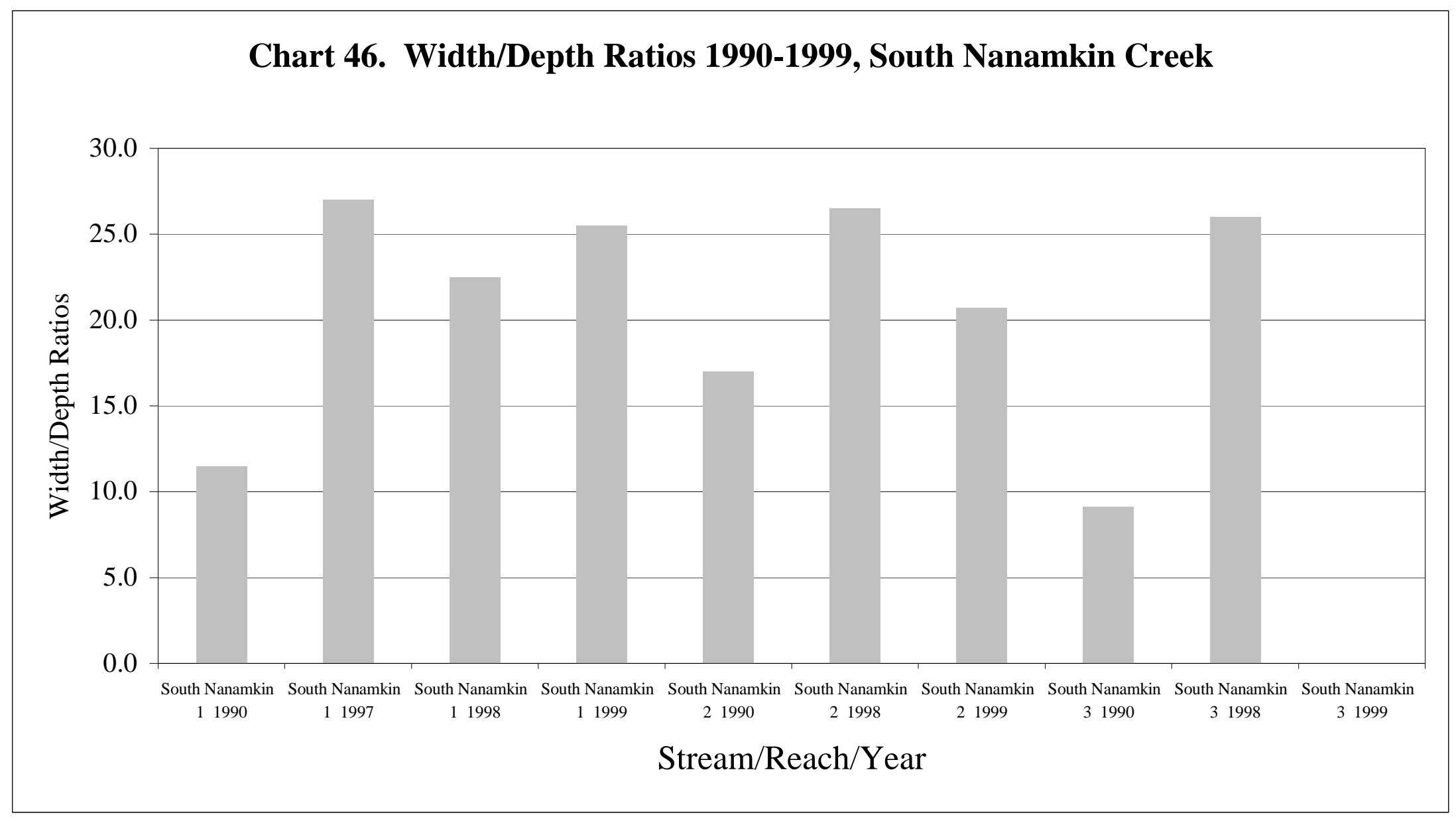




\section{Canopy closure}

Canopy closure, although an important component, seems to be difficult to measure and average the values per segment. The data was taken with a densiometer in four directions and at multiple sites throughout the stream segments (minimum five sites per segment). Some values are suspect, such as South Nanamkin segment one with the value in 1990 of 47 percent and North Nanamkin segment two in 1991 at 17 percent, and others were not taken as the time of data collection was after leaf fall (1999 data primarily). The aforementioned suspect values are obvious when viewing the stream at any angle at the present time; South Nanamkin has more canopy closure now (but not much at all) and North Nanamkin Creek has not increased compared to 1990-1991. Due to suspect data and sampling periods after leaf fall the canopy closure trends cannot be done with any confidence. The West Fork Hall Creek value does have some interest as the values were rechecked. The 66 percent value is strictly derived from coniferous trees as the data was taken in November. In 2000 the $1^{\text {st }}$ and $2^{\text {nd }}$ segments of North Nanamkin were rechecked with a very slight increase South Nanamkin segment 2 should a slight decrease.

Table 32. Percent Shade 1990-1999.

\begin{tabular}{|l|r|r|r|r|r|}
\hline & \multicolumn{1}{|l|}{$\mathbf{1 9 9 0 - 9 1}$} & $\mathbf{1 9 9 7}$ & $\mathbf{1 9 9 8}$ & $\mathbf{1 9 9 9}$ & $\mathbf{2 0 0 0}$ \\
\hline Stream/Segment & \multicolumn{1}{|l|}{ Percent } & & & & \\
\hline Blue VS1 & 42 & 16 & & 74 & \\
\hline Blue VS2 & 52 & & & 84 & \\
\hline Blue VS3 & 37 & & & & \\
\hline Iron VS1 & 60 & 27 & 16 & & \\
\hline Iron VS2 & 66 & 79 & 66 & & \\
\hline Louie VS1 & 49 & 59 & & & \\
\hline Louie VS2 & 0 & 13 & 21 & 29 & 29.3 \\
\hline North Nanamkin VS1 & 17 & 50 & 44 & 56 & 56.1 \\
\hline North Nanamkin VS2 & & 66 & 66 & & \\
\hline North Nanamkin VS3 & 47 & 13 & 12 & 16 & \\
\hline South Nanamkin VS1 & 48 & & 61 & 66 & 65.1 \\
\hline South Nanamkin VS2 & 41 & & 53 & & \\
\hline South Nanamkin VS3 & & & & 66 & \\
\hline Westfork Hall & & & & & \\
\hline
\end{tabular}

\section{Improvement/Structure Surveys}

Surveys of the instream structures/improvements and planted vegetation have been completed annually. The two following sections describe the results of those surveys. Vegetation was planted on North and South Nanamkin Creek and Blue Creek, but no initial or follow up surveys were done on Blue Creek. Structures/improvements were done on all five streams, and in two separate places in North Nanamkin Creek (segment one and three).

\section{Plants}

Plant surveys were done to determine plant survival on North and South Nanamkin Creeks. Approximately ten percent of the plants have survived (Table 33). Losses stem from lack of water, animal and flood damage. Many of the plants have been grazed by livestock; deer may have grazed some plants. Some beaver damage occurred immediately after many cuttings were planted (1995), and since then beavers have occasionally taken out a few plantings per year. Plant survival varied by species: from high to low- cottonwood, chokecherry, red osier dogwood, ponderosa pine, and black hawthorn (percentages vary depending on which 1993 and 1995 report is used). None of the cuttings or greenhouse cuttings survived.

The fencing that was installed to prevent livestock damage to riparian plants has not always been very effective. The livestock were relatively wild when approached and ran right through the fencing, and therefore the fencing is continuously in need of repair. Several sections of fence that were down in 1998 were repaired in 1999, and since that time less maintenance has been needed. Hanging gates were installed 
where the stream enters or leaves a fenced section for livestock access to water. These gates were designed to be removed during winter and spring. In most instances, the hanging gates were not removed in winter and were still in place when spring floodwaters occurred. At all but one gate, large gravel bars have formed, and in some cases some damage to the channel has occurred. All gates were removed in November/December of 1998 to prevent this from occurring this spring. The gates have all been replaced by fencing with numerous stays and have shown to be as effective and reduced maintenance.

Table 33. Plant Survival and Species List.

July 1993 Monthly Report survivals.

\begin{tabular}{|l|r|r|r|r|l|l|}
\hline & Live & Dead & Total & $\%$ survival & Species \\
\hline North Nanamkin & 750 & 220 & 970 & 77.3 & P.pine \\
\hline South Nanamkin & 4238 & 60 & 4298 & 98.6 & Cottonwood \\
\hline \multicolumn{7}{|c|}{ Oct-98 } \\
\hline
\end{tabular}

\section{Structures}

In-stream structures were examined and counted to determine effectiveness. Tables 34 and 35 below depict the results for 1998 and 1999. Structures in Blue Creek were counted and assessed during the habitat surveys. The number of structures completely missing in Blue Creek is the same as the Spokane Tribe of Indians found in 1996.

Table 34. In-stream Structures 1998.

\begin{tabular}{|l|l|l|l|l|l|}
\hline Stream & $\begin{array}{l}\text { Original number } \\
\text { of structures }\end{array}$ & $\begin{array}{l}\text { Presently } \\
\text { functional }\end{array}$ & Bedload filled & Washed out & Not found \\
\hline Blue Creek & 71 & 14 & 10 & 17 & 30 \\
\hline Iron Creek & 11 & 8 & 1 & 2 & 0 \\
\hline Louie Creek & 6 & 0 & 0 & 6 & 0 \\
\hline North Nanamkin & 24 & 11 & 8 & 4 & 1 \\
\hline South Nanamkin & 14 & 8 & 2 & 4 & 0 \\
\hline
\end{tabular}

Table 35. In-stream Structures 1999.

\begin{tabular}{|l|l|l|l|l|l|}
\hline Stream & $\begin{array}{l}\text { Original number } \\
\text { of structures }\end{array}$ & $\begin{array}{l}\text { Presently } \\
\text { functional }\end{array}$ & Bedload filled & Washed out & Not found \\
\hline Blue Creek & 71 & 33 & 3 & 11 & 24 \\
\hline Iron Creek & 11 & 5 & 1 & 5 & 0 \\
\hline Louie Creek & 6 & 4 & 0 & 2 & 0 \\
\hline North Nanamkin & 24 & 9 & 4 & $* 5$ & 6 \\
\hline South Nanamkin & 14 & 8 & 2 & 4 & 0 \\
\hline
\end{tabular}

*Stream has moved to an alternative channel and now does not run over 3 structures.

In November of 1998 a contractor removed several yards of gravel from North Nanamkin Creek downstream of Highway 21. The hanging gates that were left in place during high flows may have caused depositional zones to occur. No cost was incurred, as the contractor was doing the work as off site mitigation from another area. Work was completed in one and a half days, November $29^{\text {th }}$ and $30^{\text {th }} 1998$. 
North Nanamkin Creek had previously created a new channel (channel 2) south of the original channel created for this project (channel 1). Channel 1 was cleared of gravel and sand and channel 2 blocked with the material, but not filled in beyond that point. This was done in the event the hanging gates were not the only cause of the deposition. December $12^{\text {th }}$ flood flows occurred equal to a 25 to50-year flood event (rain on snow). It appears that the meanders constructed during the second phase of this project slow the flow in the channel down enough that the bedload precipitates out and fills the channel before a meander below the gates. Presently the no water flow occurs in the constructed channel except at extreme flooding levels.

\section{CONCLUSIONS}

This report included multiple year trend and statistical analysis of data over the last 10 years. Analysis was presented on habitat (pool/riffle ratios, large woody debris, substrate etc.), fish population estimates, stream flow data, significance of the results, and success/failure of structures and data collection methods. Two sets of hypotheses for testing are:

1. The treatments (passage improvements) are effective for increasing the population of rainbow trout.

1a. The treatments (passage improvements) are not effective for increasing the population of rainbow trout.

2. The treatments (habitat improvements) are effective (e.g. pool-riffle ratios) for improving habitat in $\mathrm{X}$ stream.

2a. The treatments (habitat improvements) are not effective (e.g. pool-riffle ratios) for improving habitat in $\mathrm{X}$ stream.

Results show that passage improvements (culverts and structures for approaches to them) have probably led to higher adult fish returns, but the full effect may be masked by water year (wet vs. dry years) or inadequate detection methods. Three reaches, the highest reach of North Nanamkin, Iron and Blue Creeks, prior to 1996 had no fish present, due to manmade fish barriers, had a direct improvement since juvenile fish are now present and adults spawn in these reaches. Habitat improvements (drop structures and meander reconstruction) were marginal for the effort incurred and can not be attributed directly to increases in densities of juvenile fish or adult returns, although diversity (pool-riffle ratios) improved in North Nanamkin Creek. The pool-riffle ratios vary from year to year and are difficult to judge when examining structures; some structures were buried the first year and reappeared this last year. It does appear that some stabilization has occurred, but long term monitoring would be necessary to adequately assess the stabilization desired. Part of North Nanamkin Creek no longer flows through the recreated channel. In all streams the fish population density has increased in pools and riffles in 1998 and 1999 compared to 1990 and 1991.

Fencing and riparian vegetation plantings have been somewhat successful, but no initial goal (expectation) for survival was written. The fencing was installed to protect the riparian area on segment one of North and South Nanamkin Creek, but is only effective if maintained throughout the season. No agreement was written when the project was initialized with the landowners, and therefore after this project ends failure will most likely occur unless an agreement or additional funding for maintenance is acquired. Vegetation plantings by percentage seem low, but the soils and water availability to these plants during the dry season limited the success. The soils are poor: glacial outwash with minimal sand or loam. Water drains from these soils readily leaving new plants dry during the critical time of the year. Under these conditions plant survival can not be expected to be high. It appears that the structures, fencing and riparian restoration has had some positive effects increasing fish densities, but increased flow regimes in recent years masks, or may be the reason for, these increased densities (except for the three reaches previously mentioned, which received 100\% success through passage improvements).

An irrigation diversion improvement was initially constructed with the landowner at South Nanamkin Creek in 1995, but failed during the 1996 flooding (25-50 year event) and irrigation was abandoned by the landowner after that point (exposed, frost-split, pipes and dam breaching made it impossible to use).

There were several problems with the data collection methods used for monitoring. Juvenile and adult fish collection in the spring of the year has an inherent problem with high flows. The unique fyke-net collection unit for juveniles had been destroyed or filled with sediment and debris in high flows at least once per season and the adult picket-weir has collapsed during extreme high flows or when debris builds up 
too high in the pickets. In either case these are still good designs, but under highly variable conditions these trapping techniques are not completely effective. Fish can escape from either trap, particularly at high flows when the water approaches the top of the traps. Juvenile fish can escape by swimming back upstream out of the trap and in the case of the adult traps, some, mostly smaller, adult fish, can get through the pickets and/or the holding box with effort. The adult trapping effort loses the most data when they have to be pulled due to high flows and no fish can be trapped. Trend data can be used if relatively equal effort is used each year.

The screw trap, used on the San Poil River , was destroyed during a 50-year flood event in 1997. The replacement was used much more cautiously. Also, spring high flows prevent catching a good water column sample with this type of trap. The trap can easily catch a large portion of the thalweg at lower flows, which was done in 1998 and 1999.

Data analysis was limted when considering that the time of data collection varied for some parameters; for example, habitat data, plant surveys, population estimates were conducted at varying times. Habitat data analysis was also altered due to changes in the protocol from TFW, such as that described for substrate. Water flow controls the amount and effectiveness of data collection, and other outside influences, such as the operation of Grand Coulee Dam, alter Lake Roosevelt fish rearing conditions and entrainment. Water flows in the project streams probably affect the migration of juveniles. No fall trapping has ever been conducted (also difficult given the low flows and ice), but it is known from the channel work completed in November 1998 that the juveniles move down stream as the flows increase in North and South Nanamkin Creeks. It is possible that the juveniles move as the conditions allow and through density dependant factors, such as competition, increases. Many young of the year were captured and released in June and July that migrated to the San Poil River immediately after buttoning up. Higher base flows during the dry season affect the survival of juveniles and recruitment as well; e.g. more water (wetted habitat) produces more fish. This seems to be a major factor in the density analysis, which is the most robust of the data sets in this report.

The 2001 field season will follow the same basic protocols as in 1997-2000 to have a consistent data set. Two additional features will be attempted during spring; a creel survey of fishermen on the San Poil River and the use of the screw trap to capture juveniles is not anticipated in 2001. The screw trap will probably not be put into the San Poil River in spring of 2001 due to the needs of the other project (Chief Joseph Kokanee Enhancement Project). This attempt is to see is there is a substantial number of juveniles migrating down during the higher flows that the fyke-net type traps can not be used. It may also be used to see if it is more efficient at trapping versus the fyke-net traps. A backhoe may be needed to create a pool deep enough to accommodate the trap.

\section{Recommendations}

In the subsequent years for this project or a similar one, passage improvements through culverts should be a priority for tributaries that drain into Lake Roosevelt. Many culverts, through perching and alignment, block potential habitat for spring spawning rainbow trout, and other migrating fish, in many places across eastern Washington. The San Poil River drainage has many culvert barriers that, if corrected, would open many miles of habitat that is ideally suited for the adfluvial rainbow trout, as they have good habitat (Jones and Hunner, 1996). The increase in access can be easily monitored and evaluated by presence or absence of juveniles and adults. Other improvements, such as re-establishing flows where there are withdrawals should also be a priority, but takes much longer to achieve results. Habitat improvements do have at least some benefits, but is difficult to detect. Fencing projects to control livestock use in riparian areas should be under taken, and funding included in proposals, when maintenance is assured for a long enough time to re-establish the riparian function or when an agreement with the landowner is created. 
Maps

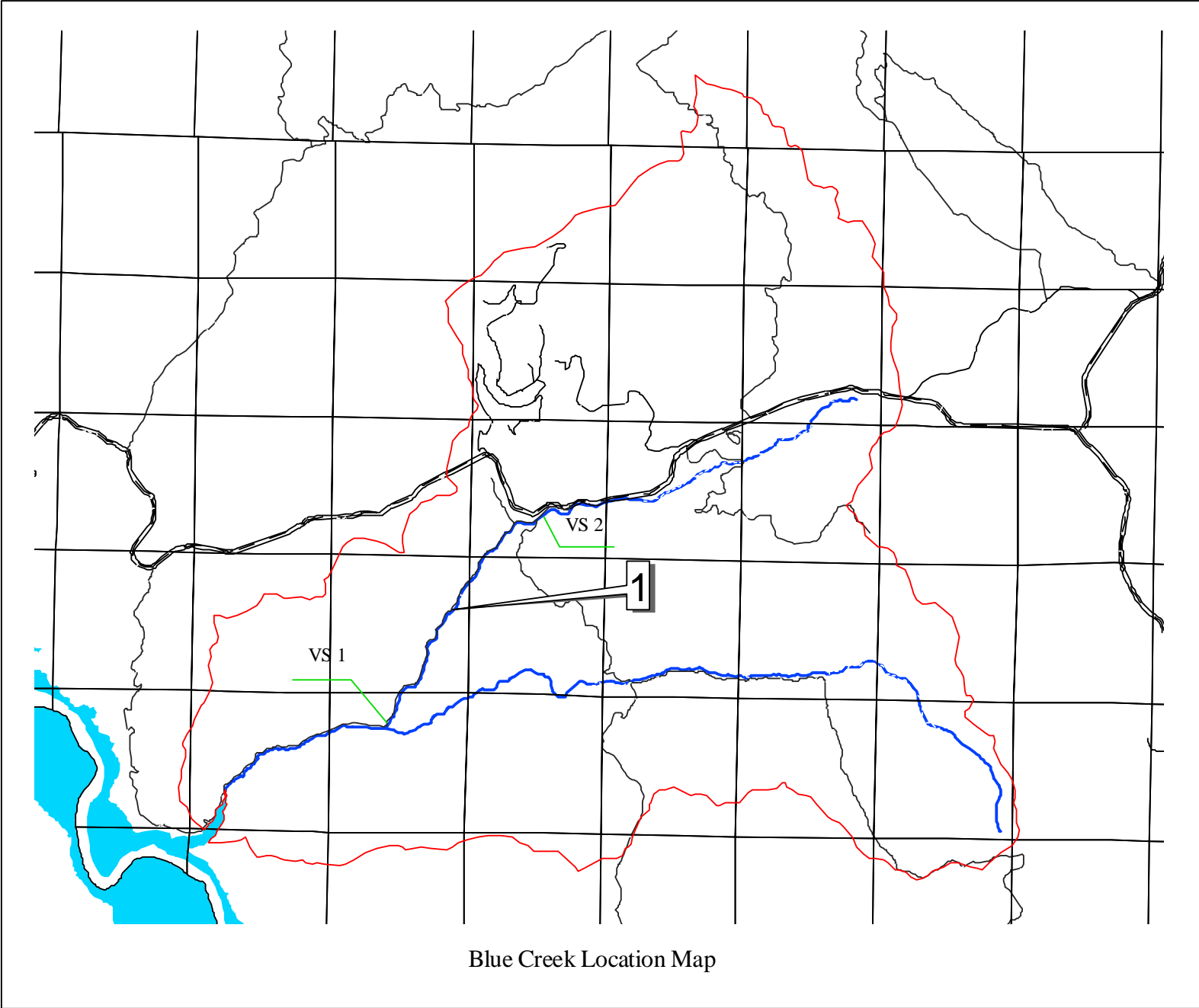




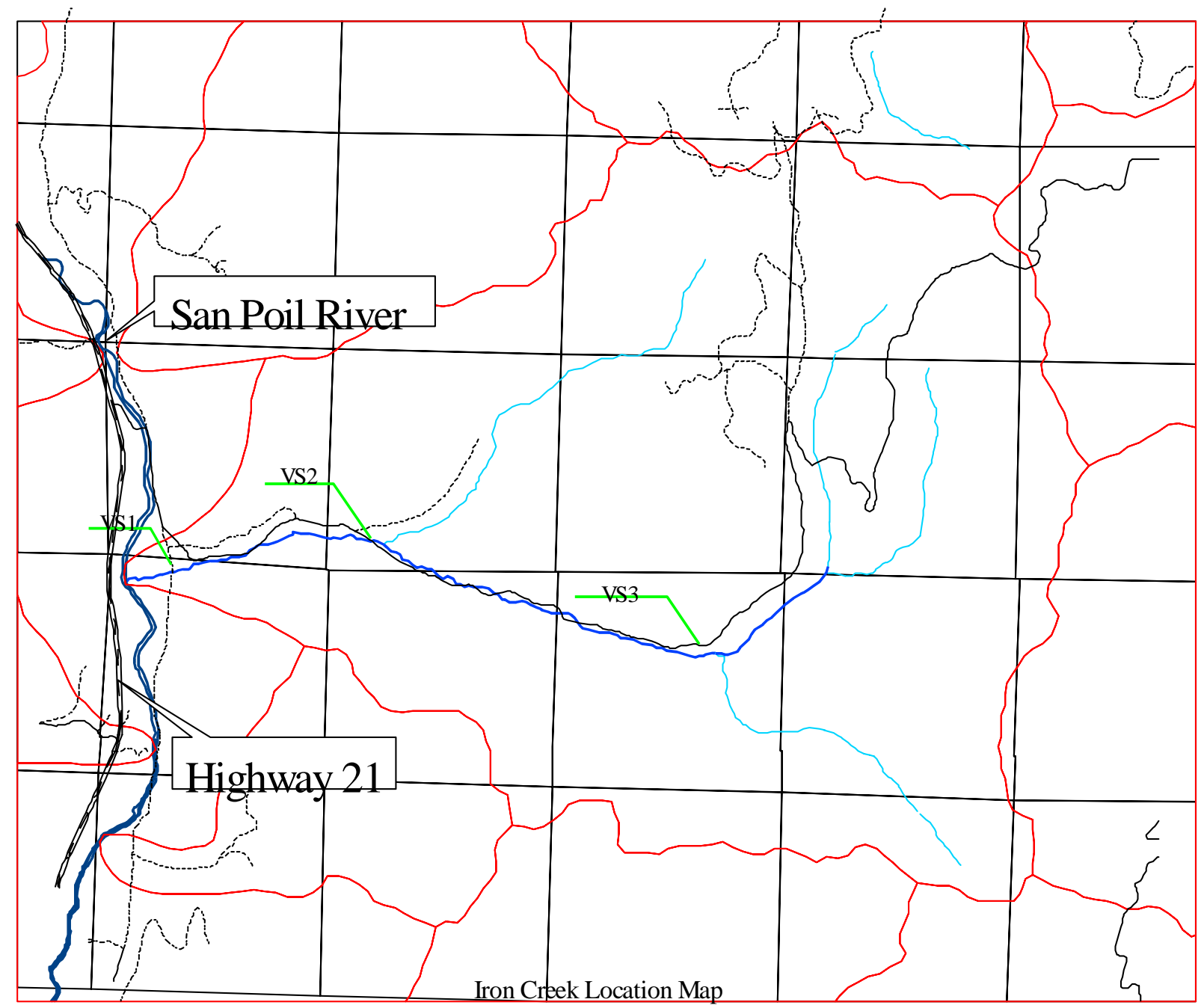




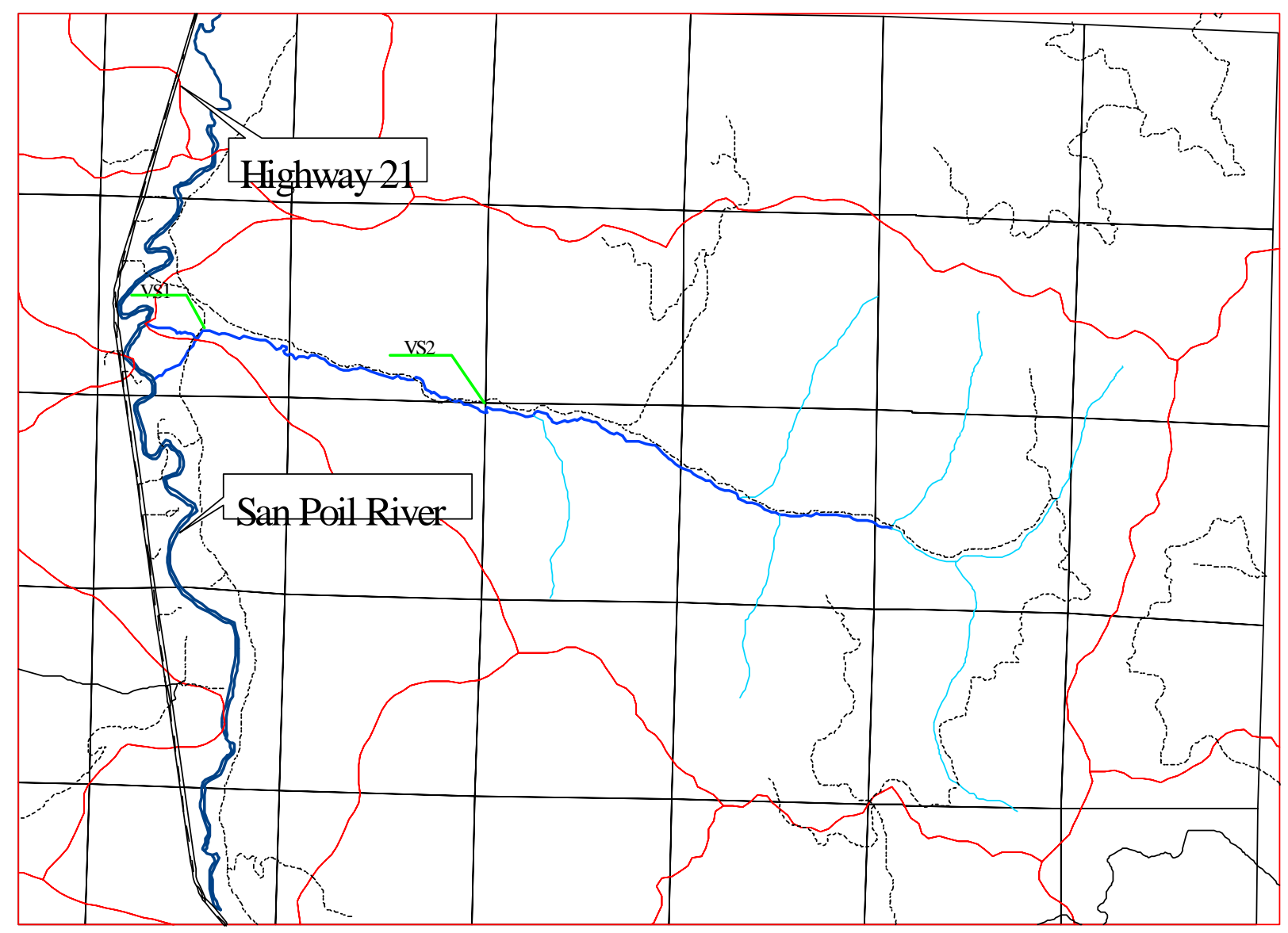

Louie Creek Location Map 


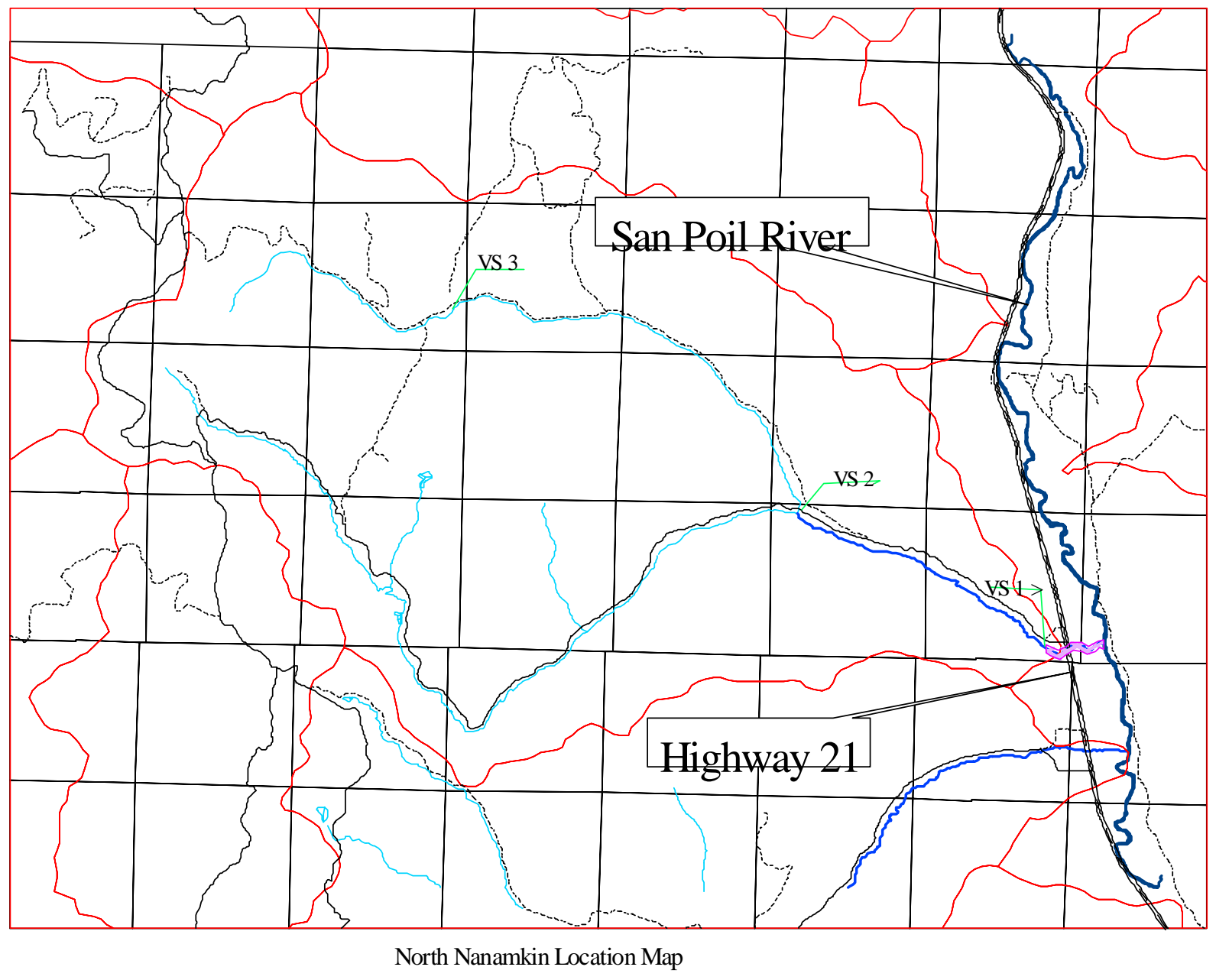




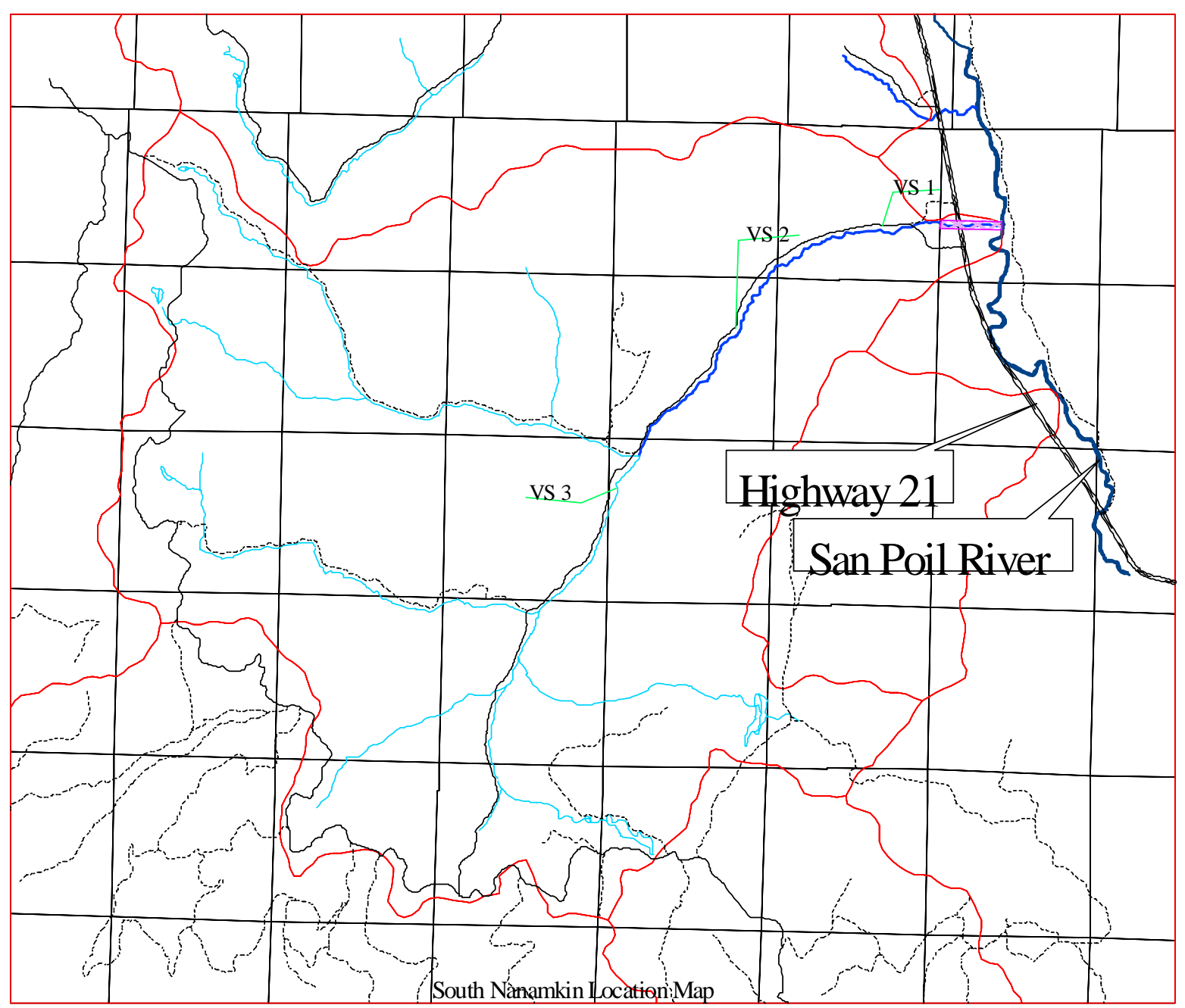

